Illinois State University

ISU ReD: Research and eData

Theses and Dissertations

10-7-2016

\title{
Effect of Cover Crops and Nitrogen Application Timing on Nutrient Loading and Concentration through Subsurface Tile Drainage
}

Michael Douglas Ruffatti

Illinois State University, mdruffa@ilstu.edu

Follow this and additional works at: https://ir.library.illinoisstate.edu/etd

Part of the Agriculture Commons

\section{Recommended Citation}

Ruffatti, Michael Douglas, "Effect of Cover Crops and Nitrogen Application Timing on Nutrient Loading and Concentration through Subsurface Tile Drainage" (2016). Theses and Dissertations. 632.

https://ir.library.illinoisstate.edu/etd/632

This Thesis is brought to you for free and open access by ISU ReD: Research and eData. It has been accepted for inclusion in Theses and Dissertations by an authorized administrator of ISU ReD: Research and eData. For more information, please contact ISUReD@ilstu.edu. 


\title{
EFFECT OF COVER CROPS AND NITROGEN APPLICATION TIMING ON NUTRIENT LOADING AND CONCENTRATION THROUGH SUBSURFACE TILE DRAINAGE
}

\author{
Michael D. Ruffatti
}

\section{Pages}

This thesis is a comprehensive analysis investigating the impact of nitrogen fertilizer application timing and cover crop integration on the distribution and concentrations of soil inorganic nitrogen and the load and concentration of nitrate, ammonium, and phosphorus of subsurface tile drainage water.

KEYWORDS: Nitrate, Ammonium, Phosphorus, Leaching, Tile Drainage, Cover Crops, Nitrogen Uptake, Water Quality, Hypoxia, Illinois, Mississippi River Basin, Nutrient Loss Reduction Strategy, Corn-Soybean Rotation, Fertilizer Timing, Illinois Nutrient Loss Reduction Strategy 
EFFECT OF COVER CROPS AND NITROGEN APPLICATION TIMING ON NUTRIENT

LOADING AND CONCENTRATION THROUGH SUBSURFACE TILE DRAINAGE

MICHAEL D. RUFFATTI

A Thesis Submitted in Partial Fulfillment of the Requirements

for the Degree of

MASTER OF SCIENCE

Department of Agriculture

ILLINOIS STATE UNIVERSITY

2016 
(C) 2016 Michael D. Ruffatti 
EFFECT OF COVER CROPS AND NITROGEN APPLICATION TIMING ON NUTRIENT

LOADING AND CONCENTRATION THROUGH SUBSURFACE TILE DRAINAGE

MICHAEL D. RUFFATTI

COMMITTEE MEMBERS:

Robert Rhykerd, Chair

Shalamar Armstrong

Diane Byers 


\section{ACKNOWLEDGMENTS}

I would like to express sincere thanks and appreciation to the people who have helped me complete this degree over the last two and a half years. First, I would like to thank my family and my fiancé Courtney Gallup who has supported me unconditionally and helped give me the motivation I needed to complete this degree. Secondly I would like to thank Dr. Shalamar Armstrong who has been my mentor and advisor. I first started working with Dr. Armstrong during my undergraduate tenure and over the past four years he has not only been a guide as a scientist and a researcher, but also has lent his advice and support as I approach all obstacles in my life. Working with Dr. Armstrong has not only given me a valued mentor and advisor, but a lifelong friend whose passion has made this project educational and enjoyable. I would also like to show my appreciation to the Illinois Nutrient Research and Education Council for providing funding and support for this research project. I would show my thanks to Corey Lacey, who trained and advised me in our research procedures and helped spark the passion that I now have as a scientist and a researcher. I would also like to thank my other committee members, Dr. Robert Rhykerd and Dr. Diane Byers, both of which provided valuable input in the writing and completion of my thesis. I would also like to show my appreciation to the other graduate students of the ACRE-1 research team, Richard Roth and Travis Deppe. Working with Rick and Travis made the countless days spent in the field with the late nights working in the lab much more memorable and enjoyable. In addition, I would like to acknowledge Phillip Brown who not only allowed us to set up our research program in his field, but has also been crucial in the planning and execution of the many management decisions. I would like to show my thanks the numerous undergraduate researchers that have worked with who have made the time spent in the field and lab much more efficient and productive. Furthermore, I would like to thank Kathy 
Scott and Mary Akers, whose friendship, advice, and administrative support made this process a much more achievable task. I would also like to acknowledge the ISU farm staff who assisted with many in-field tasks and aided in management decisions that made cultural practices and infield application much more stress-free. Finally, I would like to thank Jeff Bender who was my primary point of contact and never hesitated to meet with me and discuss/assist with anything in regard to farming practices.

M. D. R. 


\section{CONTENTS}

Page

ACKNOWLEDGMENTS

CONTENTS

iii

CHAPTER III FIGURES

vi

CHAPTER IV FIGURES

vii

CHAPTER

I. INTRODUCTION AND BACKGROUND 1

Research Hypothesis 3

Research Objectives $\quad 4$

II. $\quad$ LITERATURE REVIEW 5

Row crop History within the Upper Mississippi

River Basin

Crop Diversity/Rotation $\quad 5$

Tile Drainage 6

Fertilizer and Manure Management 6

Impact of N Management and Tile Drainage

On Water Quality $\quad 8$

$\begin{array}{ll}\text { Nitrate Reduction Management Practices } & 10\end{array}$

$\begin{array}{ll}\text { The } 4 \text { R's } & 10\end{array}$

Riparian Buffers 11

Constructed Wetlands $\quad 12$

Bioreactors 12

$\begin{array}{ll}\text { Cover Crops } & 13\end{array}$

$\begin{array}{ll}\text { References } & 15\end{array}$ 
Abstract

Introduction

Materials and Methods

Site Description $\quad 21$

Cultural Practices $\quad 25$

Soil Sampling $\quad 26$

Plant Sampling $\quad 27$

Grain Yield Sampling $\quad 28$

Statistical Analysis $\quad 30$

$\begin{array}{lr}\text { Results } & 30\end{array}$

Environmental Condition $\quad 30$

Cover Crop Dry Matter and Nitrogen Uptake $\quad 31$

Cash Crop Yields $\quad 32$

Cover Crops Impact on Soil TIN Distribution 33

Discussion $\quad 34$

Conclusion $\quad 40$

References $\quad 42$

IV. IMPACT OF COVER CROPS AND NITROGEN APPLICATION TIMING ON NUTRIENT LOADING AND CONCENTRATION OF SUBSURFACE TILE DRAINAGE

Abstract

Introduction

Materials and Methods

Site Description $\quad 49$

Cultural Practices $\quad 51$

Plant Sampling $\quad 52$

Grain Yield Sampling $\quad 52$

Water Sampling 53

Statistical Analysis $\quad 55$

$\begin{array}{ll}\text { Results } & 56\end{array}$

Environmental Condition $\quad 56$

Cover Crop Dry Matter and Nitrogen Uptake $\quad 57$

Cash Crop Yields $\quad 58$

Total Discharge $\quad 58$ 
Tile Drainage Nitrate Load 60

Flow-weighted Nitrate Concentration 61

Tile Drainage Ammonium Load 62

Flow-weighted Ammonium Concentration $\quad 62$

Tile Drainage DRP Load 63

Flow-weighted DRP Concentration 64

Discussion $\quad 65$

$\begin{array}{ll}\text { Conclusion } & 77\end{array}$

References $\quad 79$

$\begin{array}{lll}\text { V. } & \text { CONCLUSION } & 83\end{array}$

APPENDIX A: $\quad$ Tables and Figures for Chapter III $\quad 85$

APPENDIX B: $\quad$ Tables and Figures for Chapter IV 98 


\section{CHAPTER III FIGURES}

Figure $\quad$ Page

1. Tiling system of research site 23

2. Hagie STS modified with air seeder used to plant cover crops 26

3. Field activity timelines for the 2015 corn year and 2016 soybean year 29 


\section{CHAPTER IV FIGURES}

Figure $\quad$ Page

1. Water monitoring and sample collection system. 54

2. Example of a typical hydrograph with terminology 55 


\section{CHAPTER I}

\section{INTRODUCTION AND BACKGROUND}

The United States Department of Agriculture estimates that 4.8 billion dollars are spent each year removing nitrates from drinking water. The hypoxic zone in the Gulf of Mexico, as a result of excessive nutrient loading, is the second largest in the world (Rabalais et al., 2002). Excessive nutrient loading to the Mississippi River has been identified as a leading cause of hypoxic zone in the Gulf of Mexico (Rabalais et al., 2002). A direct link between nitrate $\left(\mathrm{NO}_{3-}\right.$ $\mathrm{N})$ levels in surface water and agricultural tile drainage form the Upper Mississippi River Basin (UMRB) has become a major concern. As a result, in 2008 the Environmental Protection Agency (EPA) released a Gulf Hypoxic Zone Action Plan, which required each of the 12 states in the Mississippi River Basin (MRB) to develop a strategy to reduce the amount of nutrients carried in rivers to the Gulf. To reduce nutrients lost from Illinois waters, the Illinois EPA developed the Illinois Nutrient Loss Reduction Strategy. One goal of the strategy was a $45 \%$ total reduction in loss of nutrients to the Mississippi River with a $15 \%$ reduction in $\mathrm{NO}_{3}-\mathrm{N}_{\text {by }}$ 2025 (Illinois NLRS, 2015). Therefore, there is a need to develop a nitrogen (N) management system that reduces agricultures contribution while still maintaining current productivity.

The predominant cropping system in Illinois and in most of the Midwest Corn Belt is a corn-soybean rotation. Most of the attempts at reducing NO3-N losses via subsurface tile drainage has focused on $\mathrm{N}$ fertilizer management. Studies have shown that the use of the 4 R's nitrogen management practices has shown the potential to significantly reduce $\mathrm{NO}_{3}-\mathrm{N}$ losses. Applying $\mathrm{N}$ fertilizer in the spring closer to the period of rapid cash crop uptake, applying the optimal $\mathrm{N}$ rate for a given location, selecting the correct source of $\mathrm{N}$, and the method and placement of the $\mathrm{N}$ fertilizers are all factors that have been proven to reduce $\mathrm{N}$ leaching (Scharf, 2006). However, numerous scientific studies have shown that substantial $\mathrm{NO}_{3}{ }^{-} \mathrm{N}$ losses can 
occur in the soybean phase of a corn-soybean rotation even when no $\mathrm{N}$ fertilizers have been applied (Baker et al., 1975; Dinners et al., 2002). Other $\mathrm{N}$ management practices including the use of artificial wetlands and bioreactors are proven to reduce $\mathrm{NO}_{3}-\mathrm{N}$ concentration from tile water by up to $48 \%$, but these practices capture $\mathrm{NO}_{3}-\mathrm{N}$ leaving the field by promoting denitrification (the conversion of nitrate to nitrogen gas): thus, the $\mathrm{N}$ cannot be used by the cash crop (Kovacic, 2006; Greenan, 2009). Thus, there is a need for an $\mathrm{N}$ management tool that not only reduces $\mathrm{NO}_{3}-\mathrm{N}$ loading to surface water, but also increases the efficiency and crop utilization of the $\mathrm{N}$ fertilizer. Cover crops, as a tool to capture residual $\mathrm{N}$ through uptake, has been proven to reduce $\mathrm{NO}_{3}-\mathrm{N}$ losses via leaching through subsurface tile drainage. In the Mississippi delta, Adeli et al. (2011) reported that cereal rye significantly reduced $\mathrm{NO}_{3}-\mathrm{N}$ leachate levels from fall applied broiler litter in a cotton production system. Kasper et al. (2007) studied the effects of cover crops on tile $\mathrm{NO}_{3}-\mathrm{N}$ leachate in a corn-soybean rotation with a sidedress $\mathrm{N}$ fertilizer application in Iowa. Kasper et al. (2007) determined that a rye cover crop treatment significantly reduced the average annual flow-weighted $\mathrm{NO}_{3}-\mathrm{N}$ concentration of drainage water by $50 \%$ or more compared with the control. Strock et al. (2004) studied the impact of fall established rye cover crops following a corn cash crop on $\mathrm{NO}_{3}-\mathrm{N}$ leaching with a spring application of urea $\mathrm{N}$ application and determined that over three years, the cover crops reduced $\mathrm{NO}_{3}-\mathrm{N}$ loss by $13 \%$.

While there has been extensive research on the effects of cover crops on spring applied $\mathrm{N}$ application systems, $40-75 \%$ of farmers still fall apply $\mathrm{N}$ due to easier application timing and reduced costs (Ribaudo et al., 2012; Smiciklas et al., 2008). There is a lack of research that investigates the ability of cover crops to reduce $\mathrm{NO}_{3}-\mathrm{N}$ leaching in spring versus fall applied $\mathrm{N}$ fertilizers in the Midwest Corn Belt. It is possible that fall applying $\mathrm{N}$ into a living cover crop 
stand can reduce $\mathrm{NO}_{3}-\mathrm{N}$ leachate levels comparable to a similar rate of spring applied $\mathrm{N}$. According to a study conducted by Lacey and Armstrong (2013), cover crops have the capacity to impact the distribution of inorganic nitrogen within the soil profile in a silage cropping system with convention tillage with a single fall nitrogen application. Therefore, the objectives of this study were to evaluate the coupling of two of the in-field nutrient loss reduction strategies outlined in the Illinois Nutrient Loss Reduction Strategy and investigate the ability of cover crops to reduce nutrient losses via tile drainage in both spring dominated and fall dominated $\mathrm{N}$ management systems. These comparisons will determine if cover crops in both a fall and spring $\mathrm{N}$ application system can decrease the impact of applied $\mathrm{N}_{\text {on }} \mathrm{NO}_{3}-\mathrm{N}$ leachate; therefore, reducing agricultures impact on hypoxic zone in the Gulf of Mexico. The Illinois Nutrient Loss Reduction Strategy is calling for a $15 \%$ reduction in $\mathrm{NO}_{3}-\mathrm{N}$, which would affect not only local water quality but also national water quality. However, the goal cannot be achieved unless all nitrogen management systems are improved and cover crop are one of the effective nutrient reduction strategies.

\section{Research Hypotheses}

1. All cover crop treatments will have a lower soil nitrate concentration at the environmental soil depth and increased soil ammonium concentrations at the agronomic soil depth relative to the non- cover crop treatments.

2. Cover crops will significantly reduce the nutrient load and concentration in subsurface drainage for both the spring and fall $\mathrm{N}$ application systems. 


\section{Research Objectives}

1. Investigate the efficacy of cover crops and $\mathrm{N}$ application timing to impact the distribution of soil inorganic $\mathrm{N}$ within the soil profile.

2. Determine the impact of cover crops and $\mathrm{N}$ application timing on nutrient loading and concentration in subsurface drainage. 


\section{CHAPTER II}

\section{LITERATURE REVIEW}

\section{Row Crop History within the Upper Mississippi River Basin}

\section{Crop Diversity/Rotation}

In the early 1900's farmers produced a diverse range of crops to supply food for the work animals, livestock, and their families. This led to diverse crop rotations tightly coupled with the production of livestock. Developments in crop breeding and improved genetics soon changed all of this. In 1908, G. H. Shull first developed the idea that corn yields could be improved by developing inbred lines, creating hybrids by crossing these inbred lines, and reproducing and selling the best yielding hybrids to farmers (Hallauer, 2008). The yield response was rapidly realized by farmers; in fact, by 1945 nearly 100 percent of Iowa corn acreage was planted to hybrids. A decrease in demand for forage crops and oats led to a significant reduction in the diversity of crop rotations. According to the Illinois Department of Agriculture, Illinois corn and soybean harvested acres increased by more than double from 1950 to 1997, while acres harvested for hay decreased by approximately 50 percent and oats was almost completely eliminated (Illinois Department of Agriculture). One factor contributing to diminished crop diversity was biological $\mathrm{N}$ fixation from legumes including sweet clover and alfalfa was no longer needed due to the increased use of commercial $\mathrm{N}$ inputs. Increases in the availability of commercial $\mathrm{N}$ fertilizers and the specialization of farms in the Midwest led to a separation of crop and livestock production. 


\section{Tile Drainage}

Tile drainage is also a critical aspect of row crop production systems in the Midwest. Tile drainage, or artificial subsurface tile drainage, is the practice of installing clay tiles or perforated plastic pipes into the soil to rapidly remove excess water from the root zone. In 1987, the United States Department of Agriculture (USDA) estimated approximately 110 million acres of the land within farms were being artificially drained in the United States (US) (USDA, 1987). Starting in the 1860 's, wetlands in the Midwestern United States were drained and the prairiewetland landscape have been transformed from perennial vegetation to primarily annual, shallow-rooted, corn and soybean row-crops (Baker et al 2008). An excess of 50 million acres consisting mostly of cropland, have been drained though the use of tiles, ditches, and streams in Illinois, Indiana, Iowa, Ohio, Minnesota, and Wisconsin (USDA, 1987). Through the use of tile drainage, land that was previously too saturated to farm could be transformed into highly

productive agricultural land. In row crop dominated states of the Upper Midwest, approximately $85 \%$ of the cropland is drained by tile drainage systems (Sugg, 2007). Subsurface tile drainage can provide economic benefits by creating a well-aerated environment for roots to maximize the plant's uptake of nutrients (Zucker et al., 1998). Tile drainage can also provide environmental benefits by reducing surface runoff, soil erosion, and phosphorous transport (Zucker et al., 1998).

\section{Fertilizer and Manure Management}

The increase in crop yield and the separation of livestock and crop production created a demand for a new source of nitrogen. In the early 1850's, von Liebig introduced the law of the minimum, which stated that "the yield of any crop is governed by any change in the quantity of the scarcest factor called the minimum factor and as the minimum factor is increased the yield will increase in proportion to the supply of that factor until another factor becomes the 
minimum" (Redman and Allen, 1954). The most common source fertilizer was manure, which is an organic fertilizer that slowly releases plant essential nutrients to the soil. Application of animal manures has also been shown to improve and enhance soil physical, biological, and chemical properties (King et al 2007). Despite these benefits, present day high yielding crop cultivars have higher nutrient requirements, and this demand led to the decrease in the use of organic materials and introduced the use of inorganic fertilizers. Inorganic fertilizers are defined as fertilizer materials that do not have carbon as the essential component of its chemical structure while organic fertilizers contain carbon and one or more essential elements (besides oxygen and hydrogen) that are required to for plant growth (EPA 1999). Inorganic fertilizers first became popular with the discovery of the Haber-Bosch process in 1901. Mulvaney et al, (2009) stated that the Haber-Bosch process was the conversion of inert nitrogen gas $\left(\mathrm{N}_{2}\right)$ from the atmosphere to highly reactive ammonia $\left(\mathrm{NH}_{3}\right)$, which will interact with water in the soil to convert to ammonium $\left(\mathrm{NH}_{4}{ }^{+}\right)$which is immediately available for plant use. As a result of this readily available and cheap source of $\mathrm{N}$ fertilizer, there was a rapid adoption of inorganic fertilizers in the Midwest. Between the mid-1960s and the late 1990's, the net result of this management change was a $2 \mathrm{~kg} \mathrm{ha}^{-1} \mathrm{yr}^{-1}$ increase in the use of commercial $\mathrm{N}$ fertilizers (Dinnes et al 2002). More than 49 million tons of primary nutrient (Nitrogen, Phosphorus, Potassium) commercial fertilizers were consumed in the United States in the year ending June 30, 1996, with organic fertilizers accounting for only $1 \%$ of the total (EPA 1999). In Midwestern states, especially in years when corn is being produced, nitrogen fertilizers are applied in the highest amounts in comparison to other nutrients, as it is usually the limiting factor for optimal yields (Samborski, 2009). Illinois consumed the greatest amount of single nutrient nitrogen $(\mathrm{N})$, phosphorus $(\mathrm{P})$, and potassium $(\mathrm{K})$ fertilizers in the US totaling $1.9,0.8$, and 1.0 million tons of fertilizer 
respectively (EPA 1999). While inorganic fertilizers can supply a greater concentration of readily available nutrients for crop production, these nutrients are highly susceptible to loss. Research done by the United States Department of Agriculture (USDA) - Agriculture Research Service compared the runoff of nitrate and ammonium between surface applied organic and inorganic fertilizers. They determined that surface applied animal manures were less susceptible to initial losses of $\mathrm{N}$ when compared to the manufactured fertilizers ammonium-nitrate and Sulphur-coated urea (King et al 2007). The cumulative $\mathrm{NO}_{3}-\mathrm{N}$ recovered in the runoff expressed as a percent of total applied $\mathrm{N}$ was $37 \%$ for ammonium-nitrate, $25 \%$ for Sulphur-coated urea, $10 \%$ for composted dairy manure, and $7 \%$ for poultry litter across the 10 -week study period (King et al., 2007).

\section{Impact of N Management and Tile Drainage on Water Quality}

During the shift to inorganic $\mathrm{N}$ fertilizers in the Midwestern Corn Belt, the adoption of tile drainage was also dramatically increasing. The increased demand and use of inorganic fertilizer coupled with tile drainage rapidly carrying water and water soluble nutrients from the field soon led to water quality concerns. By the 1990's, fertilized cropland in the Corn Belt region (Iowa, Illinois, and Indiana) contributed $90 \%$ of the total $\mathrm{NO}_{3}-\mathrm{N}$ entering the MississippiAtchafalaya River basin (MARB) while representing only $20 \%$ of the total watershed area (USDA, 2007). In 1974, Congress passed the Safe Drinking Water Act, which required the Environmental Protection Agency (EPA) to determine the maximum contaminant level in drinking water in which no adverse health effects are likely to occur. Elevated $\mathrm{NO}_{3}-\mathrm{N}$ concentrations in drinking water can cause adverse health effects on humans and animals. The maximum contaminant level (MCL) for $\mathrm{NO}_{3}-\mathrm{N}$ in drinking water in the United States is currently set at $10 \mathrm{ppm}$ of $\mathrm{NO}_{3}-\mathrm{N}$. The MCL standard for drinking water was set primarily to 
prevent methemoglobinemia or blue baby syndrome in infants (National Academy of Sciences, 1981). Excess $\mathrm{NO}_{3}-\mathrm{N}$ concentration in drinking water as carcinogen is also currently being investigated.

Hypoxic, or water low in dissolved oxygen, have always naturally existed, but the increase of hypoxia in shallow coastal areas are most likely caused by human activities (Rabalais, 2002). The coastal hypoxic zone in the Gulf of Mexico is the second largest in the world and is often referred to as the "Dead Zone" due to the fact aquatic and marine life ecosystems cannot survive in these areas (Rabalais 2002; Renaud, 1986). About $80 \%$ of the estimated freshwater discharge from the United States is supplied from the Mississippi and Atchafalaya River basin (MARB) (Goolsby, 2001). The MARB is the third largest basin in the world and drains about $41 \%$ of the continental United States with about $58 \%$ of the basin being cropland (Goolsby 2001). The MARB extends across 30 states ranging from the Appalachian Mountains in the east to the Rocky Mountains in the west. The central portion of the basin produces the majority of the corn grown in the United States and is subject to intensive agricultural drainage, fertilizer applications, and tillage practices to make the land more suitable for crop production (Goolsby 2001). Since the 1950's, $\mathrm{NO}_{3}-\mathrm{N}$ levels in the Mississippi River and the severity of the hypoxic region in the Gulf of Mexico have paralleled the increase of inorganic fertilizer production within the Mississippi River basin (Tuner et al, 1991). Nitrate loading from the Upper Mississippi River basin (includes portions of Illinois, Iowa, Missouri, and Wisconsin) accounts for roughly 35 percent of the $\mathrm{NO}_{3}-\mathrm{N}$ entering the Gulf of Mexico even though the UMRB covers less 20 percent of the Mississippi River basin (Alexander et al., 1995). A direct link between subsurface tile drainage and increased transport of nonpoint-source pollution, particularly $\mathrm{NO}_{3}-\mathrm{N}$, to surface waters has become a primary concern (Dinnes et al., 
2002). Nitrate, the most soluble and mobile form of nitrogen, is easily leached through the soil profile and into the tile drainage by precipitation (Goolsby, 2001). Excess nutrients like $\mathrm{NO}_{3}-\mathrm{N}$ in surface waters is directly linked to hypoxic zones. To address this problem, the Mississippi River/Gulf of Mexico Watershed Nutrient Task Force was formed. This Task Force developed a plan to help protect local streams and to reduce average the size of the hypoxic zone to 5,000 $\mathrm{km}^{2}$ by 2015 (Action Plan, 2008). Illinois and 11 other states in the Mississippi River basin were required to develop strategies to reduce the nutrient loads leaving their borders. Illinois's Nutrient Reduction Strategy has a goal of reducing total nutrient loss by $45 \%$ with a $15 \%$ reduction in $\mathrm{NO}_{3}-\mathrm{N}$ leaching by 2025 (EPA, 2015). The Illinois Nutrient Loss Reduction Strategy outlines several in-field and edge of field practices that have been proven in scientific studies to reduce nutrient loading to surface waters from agricultural fields.

\section{Nitrate Reduction Management Practices}

\section{The 4 R's}

Through the use of best management practices, producers can reduce $\mathrm{NO}_{3}-\mathrm{N}$ lost via tile drainage. The $4 \mathrm{R}$ 's are $\mathrm{N}$ fertilizer management practices to decrease the potential of losses from $\mathrm{N}$ fertilizers. The $\mathrm{N}$ management $4 \mathrm{R}$ 's are: the right timing, right rate, right source, and right placement of $\mathrm{N}$ fertilizers. Applying $\mathrm{N}$ fertilizers in the spring, as opposed to the fall, closer to rapid uptake of the cash crop can significantly reduce N loss (Scharf, 2006; Randall, 2005). While there has been extensive research on the benefits of spring applied N, 40-75\% of farmers in the Midwest still apply a portion of the $\mathrm{N}$ fertilizers in the fall due to easier application timing and reduced costs (Ribaudo et al., 2012; Smiciklas et al., 2008). Determining the recommended $\mathrm{N}$ rate on a field basis rather than a regional or state level and by applying a variable rate instead of a uniform rate, producers can increase the efficacy of their $\mathrm{N}$ application 
and avoid over applying $\mathrm{N}$ (Dinnes, 2002). The use of additives in $\mathrm{N}$ fertilizers has also been determined to reduce the amount of $\mathrm{NO}_{3}-\mathrm{N}$ lost. The two most common additive are Agrotain and N-Serve. N-Serve is a nitrification inhibitor that is used with anhydrous ammonia to slow down the conversion of the $\mathrm{NH}_{4}{ }^{+}$to $\mathrm{NO}_{3}-\mathrm{N}$ (Scharf, 2006). Agrotain is a urease inhibitor that is primarily used with urea. When urea is left on the soil surface, it is susceptible to loss to the air, and Agrotain can be coated on urea granules and is effective at delaying $\mathrm{N}$ loss (Scharf, 2006). Accurate placement of the fertilizer source is considered essential to minimize nitrogen losses throughout the growing season. There are many application methods for nitrogen, including broadcast application, surface banding and direct injection; however, injecting or incorporating the nitrogen fertilizers into the soil can reduce leaching and losses to the atmosphere (USDA, NRCS 2006).

\section{Riparian Buffers}

The USDA defines riparian buffers as a band of herbaceous plants grown parallel to river, stream, or body of water. According to the Illinois Nutrient Loss Reduction Strategy, riparian buffers are an edge of field practice to reduce $\mathrm{NO}_{3}-\mathrm{N}$ losses by promoting plant uptake and denitrification in the water that passes through them. Denitrification is the conversion of $\mathrm{NO}_{3}-\mathrm{N}$ to $\mathrm{N}$ gas and this process is carried out by microorganisms in anaerobic (lack of oxygen) conditions. This method has proven to be effective in reducing $\mathrm{NO}_{3}-\mathrm{N}$ losses to streams in the non-tiled regions on the state, but in the tiled regions, much of the drainage water bypasses the buffer. The Illinois Nutrient Loss Reduction Strategy estimates that approximately $64 \%$ of the state's agricultural streams do not have buffer and if buffers were to be installed on all agricultural streams there would be an $8.7 \%$ reduction in $\mathrm{NO}_{3}-\mathrm{N}$ load compared to the baseline. 
One of the main concerns with buffers for farmers is that it takes land out of production in addition to the fact that this does not help keep nitrogen in the field for the cash crops to use.

\section{Constructed Wetlands}

The primary mechanism of nitrate removal within a constructed wetland is

denitrification. Artificial wetlands have been proven to decrease $\mathrm{NO}_{3}-\mathrm{N}$ leaching up to $48 \%$ by again slowing the movement of water to streams and promoting denitrification (Kovacic, 2006). One of the concerns farmers have with constructed wetlands is it takes in order for them to be effective, the wetlands have to be at least $5 \%$ of the size of the area being drained. In addition, wetlands may not be effective at reducing nitrate leaching during months with high precipitation and will need to be routinely dredged to maintain efficiency. Xue et al. (1999) concluded that months with high precipitation resulted in smaller $\mathrm{N}$ residence time and only a small percentage of $\mathrm{N}$ being denitrified by wetlands.

\section{Bioreactors}

Bioreactors are designed to intercept drainage water and enhance denitrification of $\mathrm{NO}_{3}-$ $\mathrm{N}$ by slowing down the water and supplying microorganisms with a carbon source like wood chips. Greenan et al. (2009) determine that bioreactors have the ability to remove $30-100 \%$ of $\mathrm{NO}_{3}-\mathrm{N}$ present in tile drainage depending of the flow rate of the water, but it is assumed that the effectiveness of bioreactors decrease overtime. As the microorganisms consume the carbon source through the denitrification process, the effectiveness of the bioreactor to remove $\mathrm{NO}_{3}-\mathrm{N}$ form the tile water decreases, so the carbon source needs to be replace overtime, which is an expensive process. 


\section{Cover Crops}

Cover crops have also been proven to reduce $\mathrm{NO}_{3}-\mathrm{N}$ leaching in a spring applied $\mathrm{N}$ fertilizer management system. Cover crops are customarily defined as a catch crop grown to cover the ground during the typically fallow period of the cash crop rotation to protect the soil from erosion and from loss of plant nutrients through leaching and runoff (Reeves et al., 1994). Planting an annual cover crop to sequester residual nitrogen from an agricultural field after harvesting a previous cash crop has also been well research (Ranells, 1997; McCracken et al., 1994). The mineralization and nitrification of cover crop residue has the ability to supply following crops with nitrogen required to efficiently produce a high yielding crop while providing ground cover and minimizing environmental degradation (Doran et al., 1990). Kasper et al. (2007) studied the effects of cover crop on tile $\mathrm{NO}_{3}-\mathrm{N}$ leachate in a corn-soybean rotation, sidedress $\mathrm{N}$ fertilizer application in Iowa and determined that the rye cover crop treatment significantly reduced the average annual flow-weighted $\mathrm{NO}_{3}-\mathrm{N}$ concentration of drainage water by $50 \%$ or more compared with the control. Kladivko et al. (2004) monitored $\mathrm{NO}_{3}-\mathrm{N}$ tile drainage concentration and load in a spring fertilizer application system as affected by $\mathrm{N}$ rate, tillage system, and cover crops and observed a significant decrease in $\mathrm{NO}_{3}-\mathrm{N}$ load and concentration over a 15-year period; however, the design of the drainage experiment did not allow for testing each of the factors individually. Strock et al. (2004) studied the impact of fall established rye cover crops following corn on $\mathrm{NO}_{3}-\mathrm{N}$ leaching in a spring application of urea $\mathrm{N}$ application system and determined that over three years, the cover crops reduced $\mathrm{NO}_{3}-\mathrm{N}$ loss by 13\%. While there has been extensive research on the effects of cover crops on spring applied $\mathrm{N}$ application systems, 40-75\% of farmers still fall apply N (EPA, 2007; Ribaudo et al., 2012). This is mainly due to less time restrictions in the fall and lower fertilizer costs. There is a lack of 
research that investigates the ability of cover crops to reduce tile $\mathrm{NO}_{3}-\mathrm{N}$ leaching in spring versus fall applied $\mathrm{N}$ in the Midwest corn-belt. According to a study by Lacey and Armstrong (2013), fall applying $\mathrm{N}$ without cover crops resulted in a greater percentage of soil $\mathrm{NO}_{3}-\mathrm{N}(40 \%)$ in the 50- to $80-\mathrm{cm}$ depth of the soil profile, compared with only 31 and $27 \%$ when tillage radish and cereal rye were present at $\mathrm{N}$ application, reducing its potential for loss via tile drainage. In Mississippi river delta, Adeli et al. (2011) reported that cereal rye significantly reduced $\mathrm{NO}_{3}-\mathrm{N}$ leachate levels from fall applied broiler liter in a cotton production system. Therefore, the purpose of this study is to determine the impact of cover crops and $\mathrm{N}$ application timing on the distribution of inorganic $\mathrm{N}$ within the soil profile and nutrient leachate via subsurface tile drainage in a typical Midwestern corn-soybean tile drained production system. 


\section{REFERENCES}

"2008 Action Plan and Related Documents | Gulf of Mexico Hypoxia, Mississippi Basin | US EPA." 2008 Action Plan and Related Documents | Gulf of Mexico Hypoxia, Mississippi Basin | US EPA. Environmental Protection Agency, 2008. Web. 25 Mar. 2015

"Illinois Nutrient Loss Reduction Strategy." Illinois Nutrient Loss Reduction Strategy. Environmental Protection Agency, n.d. Web. 25 Mar. 2015.

Adeli, A., H. Twolde, J. Jenkins, and D. Rowe. 2011. Cover Crop Use for managing broiler litter applied in the fall. Agronomy Journal. 103:200-210.

Alexander, R.B., R.A. Smith, and G.E. Schwarz. 1995. The regional transport of point and nonpoint source nitrogen to the Gulf of Mexico. In Proc. Gulf of Mexico Hypoxia Conf., Kenner, LA. 5-6 Dec. 1995. USEPA Publ. 855R97001. USEPA Natl. Cent. For Environ. Publ. and Inf., Washington, DC and Prospects: Economic Research Service, Miscellaneous Publication No. 1455. 170 p.

Baker, J.L., M.B. David, D.W. Lemke, and D.B. Jaynes. 2008. Understanding nutrient fate and transport, including the importance of hydrology in determining field losses, and potential implications for management systems to reduce those losses. p. 1-17. In Upper Mississippi River Subbasin Hypoxia Nutrient Committee (ed.) Final report: Gulf hypoxia and local water quality concerns workshop. Am. Soc. of Agricultural and Biological Engineers, St. Joseph, MI.

Dinnes, D.L., D.L. Karlen, D.B. Jaynes, T.C. Kaspar, J.L. Hatfield, T.S. Colvin, and C.A.Cambardella. 2002. Nitrogen management strategies to reduce nitrate leaching in tile-drained Midwestern soils. Agron. J. 94:153-171. doi:10.2134/agronj2002.0153

Doran, John W. "Nitrogen Cycling." Role of Cover Crops in Nitrogen Cycling (1990): n. pag. SWCS. Web. 23 Feb. 2014.

EPA. 1999. Background Report on Fertilizer Use, Contaminants, and Regulations. Washington, D.C.: National Program Chemicals Division, Office of Pollution Prevention and Toxics, U.S. Environmental Protection Agency, 1999. Jan. 1999. Web. 9 Feb. 2015

Goolsby, Donald A., Battaglin, William A., Aulenbach, Brent T., Hooper, Richard P. "Nitrogen Input to the Gulf of Mexico" joenq 2001. 30:329-336. doi:10.2134/jeq2001.302329x

Greenan, C., T. Moorman, T. Parkin, T. Kaspar, and D. Jaynes. 2009. Denitrification in Wood Chip Bioreactors at Different Water Flows. Journal of Environmental Quality. 38:16641671.

Hallauer, Arnel R., "Corn Breeding" (2008). Iowa State Research Farm Progress Reports. Paper 549. http://lib.dr.iastate.edu/farms_reports/549

Illinois Department of Agriculture. Crop History. Illinois Department of Agriculture, n.d. Web. 03 Feb. 2015. 
Kaspar, T.c., D.b. Jaynes, T.b. Parkin, and T.b. Moorman. "Rye Cover Crop and Gamagrass Strip Effects on NO Concentration and Load in Tile Drainage." Journal of Environment Quality 36.5 (2007): 1503-511. 2007. Web. 23 Feb. 2015.Sugg, Zachary. "Assessing U.S. Farm Drainage: Can GIS Lead to Better Estimates of Subsurface Drainage Extent?" N.p., Aug. 2007. Web. 19 Feb. 2015.

King, K. W., and H. A. Torbert. "Nitrate and Ammonium Losses from Surface-applied Organic and Inorganic Fertilizers." The Journal of Agricultural Science 145.04 (2007): 385.16 Jan. 2007. Web. 9 Feb. 2015.

Kladivko, E. J., J. R. Frankenberger, D. B. Jaynes, D. W. Meek, B. J. Jenkinson, and N. R. Fausey. "Nitrate Leaching to Subsurface Drains as Affected by Drain Spacing and Changes in Crop Production System." Journal of Environment Quality 33.5 (2004): 1803-813. Web.

Kovacic, D., R. Twait, M. Wallace, and J. Bowling. 2006. Use of created wetlands to improve water quality in the Midwest - Lake Bloomington case study. Ecological Engineering. 28:258-270.

Lacey, Corey G., and Shalamar D. Armstrong. "In Field Measurements of Nitrogen Mineralization Following Fall Applications of N and the Termination of Winter Cover Crops." Air, Soil and Water Research (2013): n. pag. Department of Agriculture, Illinois State University, Normal, IL, USA., 31 Jan. 2013. Web. 27 Feb. 2015.

McCracken, D., M. Smith, J. Grove, C. MacKown, and R. Blevins. 1994. Nitrate Leaching as Influenced by Cover Cropping and Nitrogen Source. Soil Science Society of America Journal. 58:1476-1483.

Mulvaney, R. L., S. A. Khan, and T. R. Ellsworth. 2009. Synthetic Nitrogen Fertilizers Deplete Soil Nitrogen: A Global Dilemma for Sustainable Cereal Production. J. Environ. Qual. 38:2295-2314. doi:10.2134/jeq2008.0527

National Academy of Sciences_-National Research Council Academy of Life Sciences. The Health Effects of Nitrate, Nitrite, and N-Nitroso Compounds. Washington DC: National Academy of Sciences Press, 1981.

Rabalais, N.N., R.E. Turner, and W.J. Wiseman. 2002. Gulf of Mexico hypoxia, A.K.A. "The Dead Zone".Annu. Rev. Ecol. Syst. 33:235-263.

Randall, G., and J. Vetsch.2005. Nitrate Losses in Subsurface Drainage from a corn-soybean rotation as affected by Fall and Spring application of Nitrogen and nitraphyrin. Journal of Environmental Quality. 34:590-597.

Ranells, N. Nitrogen-15 recovery and release by rye and crimson clover cover crops. Soil Sci. Soc. Am. J. 1997. 61:943-948.

Redman, J.C. and S.Q. Allen. 1954. "Some Interrelationships of Economic and Agronomic Concepts." Journal of Farm Economics, 36(1), 13. 
Reeves, D. W. 1994. Cover crops and rotations. pp.125-172. In: J.L. Hatfield and B.A. Stewart (eds.) Crops Residue Management. Advances in Soil Science. Lewis Publishers, Boca Raton, FL.

Renaud, M.L. 1986. Hypoxia in Louisiana coastal waters during 1983: implications for fisheries. Fish. Bull. 84:19-26

Ribaudo, Marc, Michael Livingston, and James Williamson. Nitrogen Management on U.S. Corn Acres, 2001-10, EB-20. U.S. Dept. of Agriculture, Economic Research Service, November 2012.

Samborski, S. M., N. Tremblay, and E. Fallon. 2009. Strategies to Make Use of Plant SensorsBased Diagnostic Information for Nitrogen Recommendations. Agron. J. 101:800-816. doi:10.2134/agronj2008.0162Rx

Scharf, P.C. "Best Management Practices for Nitrogen Fertilizer in Missouri." Nutrient Management. Missouri University Division of Plant Sciences, Aug. 2006. Web. 25 Mar. 2014. <Best Management Practices for Nitrogen - Nutrient Management.htm>.

Smiciklas, K.D., A.S. Moore, and J.C. Adams. 2008. Fertilizer nitrogen practices and nitrate levels in surface water within an Illinois watershed. J. Agron. Educ. 37:14-19

Strock, J. S., P. M. Porter, and M. P. Russelle. "Cover Cropping to Reduce Nitrate Loss through Subsurface Drainage in the Northern U.S. Corn Belt." Journal of Environmental Quality 33.3 (2004): 1010-016. May 2004. Web. 23 Feb. 2015.Adeli, A., H. Twolde, J. Jenkins, and D. Rowe. 2011. Cover Crop Use for managing broiler litter applied in the fall. Agronomy Journal. 103:200-210.

Sugg, Zachary. "Assessing U.S. Farm Drainage: Can GIS Lead to Better Estimates of Subsurface Drainage Extent?" World Resources Institute, n.d. Web.

Turner, R.E., and N.N. Rabalais. 1991. Changes in Mississippi River water quality this century. Implications for coastal food webs. Bio Science 41:140-147.

U.S. Dept. of Agriculture, Agricultural Research Service, Sharpley, Andrew N. "What Are Best Management Practices." Best Management Practices to Minimize Agricultural Phosphorus Impacts on Water Quality. University Park, Pa.?: 2007. 1-3.

USDA. Pavelis, George A., Ed. 1987. Farm Drainage in the United States: History, Status, and Prospects. USDA-ERS Miscellaneous Publication Number 1455. Washington, DC.

Xue, Y., D. Kovacic, M. David, L. Gentry, R. Mulvaney, and C. Lindau. 1999. In situ measurements of denitrification in constructed wetlands. Journal of Environmental Quality. 28:263-269.

Zucker, L.A. and L.C. Brown (Eds.). 1998. "Agricultural Drainage: Water Quality Impacts and Subsurface Drainage Studies in the Midwest." Ohio State University Extension Bulletin 871. The Ohio State University. Online at http:// ohioline.osu.edu/b871/index.html. 


\title{
CHAPTER III
}

\section{IMPACT OF COVER CROPS AND NITROGEN APPLICATION TIMING ON THE DISTRIBUTION ON SOIL INORGANIC N}

\begin{abstract}
It has been estimated that nitrate $\left(\mathrm{NO}_{3}-\mathrm{N}\right)$ leaching from artificially drained agricultural fields in the Upper Mississippi River Basin accounts for approximately $65 \%$ of nitrogen (N) delivered annually to the Gulf of Mexico. Therefore, the objectives of this study were to investigate the impacts of fertilizer application timing and cover crop (CC) adoption on the distribution of distribution of total inorganic N (TIN). This experiment was conducted at the Illinois State University Nitrogen Management Research Field Station, in Lexington, Illinois. Treatments included a Zero Control (no $\mathrm{N}$ fertilizer and no cover crop), a fall dominated $\mathrm{N}$ application (70\% fall, 30\% spring) with and without $\mathrm{CC}$, and a spring dominated $\mathrm{N}$ application ( $20 \%$ fall, $80 \%$ spring) with and without CC. A total rate of $224 \mathrm{~kg} \mathrm{~N} \mathrm{ha}^{-1}$ was applied to all treatments, except the Zero Control. Spring cover crop sampling revealed an average aboveground cover crop biomass of $1,165 \mathrm{~kg} \mathrm{ha}^{-1}$ and an average $\mathrm{N}$ uptake of $42.5 \mathrm{~kg} \mathrm{~N} \mathrm{ha}^{-1}$. Soil samples were collected in the spring at four separate depths and analyzed for inorganic N. Regardless of $\mathrm{N}$ fertilizer application system, over the course of the study cover crops demonstrated the ability to decrease the concentration of $\mathrm{NO}_{3}-\mathrm{N} 33-62 \%$ within the soil profile. The addition of cover crops also reduced the amount of $\mathrm{NO}_{3}-\mathrm{N}$ within the lower depths of the soil profile by $17 \%$ in the fall system and $37 \%$ in the spring system. The Illinois Nutrient Loss Reduction Strategy presents a target reduction in $\mathrm{NO}_{3}-\mathrm{N}$ losses by $15 \%$ by 2025 . This data demonstrates that $\mathrm{CC}$ have the potential to significantly reduce the $\mathrm{NO}_{3}-\mathrm{N}$ concentration within
\end{abstract}


the soil profile in both spring and fall dominated $\mathrm{N}$ management systems, reducing the potential for $\mathrm{NO}_{3}-\mathrm{N}$ losses. 


\section{Introduction}

Nitrate leaching from both spring and fall $\mathrm{N}$ fertilizer applications in agricultural fields is a leading contributor to surface water loading and the hypoxic zone in the Gulf of Mexico (Rabalais et al., 2002). As a result, in 2008 the Environmental Protection Agency (EPA) released a Gulf Hypoxic Zone Action Plan, which required each of the 12 states in the Mississippi River Basin (MRB) to develop a strategy to reduce the amount of nutrients carried in rivers to the Gulf of Mexico. To reduce nutrients lost from Illinois waters, the Illinois EPA developed the Illinois Nutrient Loss Reduction Strategy. One goal of the strategy is a $45 \%$ reduction in the nutrient load to the Mississippi River with a $15 \%$ reduction in $\mathrm{NO}_{3}{ }^{-} \mathrm{N}$ loading by 2025 (EPA, 2015). Therefore, there is a need to develop a nitrogen (N) management system that reduces nutrients lost from agricultural systems while still maintaining current productivity.

In additions to the edge-of-field practices such as riparian buffers and bioreactors and infield practices such as the 4 R's, cover crops can be used N management tool. Typically cover crops are used as a catch crop to cover the ground during the typically fallow period of the cash crop rotation; protecting the soil from erosion and loss of plant nutrients through leaching and runoff (Reeves et al., 1994). Cover crops are commonly in conjunction with a spring $\mathrm{N}$ fertilizer application system to scavenge residual nitrogen between cash crops growing seasons. In a fouryear study done by Kasper et al. in Iowa (2004), the inclusion of cover crops resulted in a significant reduction in TIN in the soil profile in after harvest soil samples. While there has been extensive research on the effects of cover crops on spring applied $\mathrm{N}$ application systems, 40-75\% of farmers still fall apply $\mathrm{N}$ due to easier application timing and reduced costs (EPA, 2007; Ribaudo et al., 2012; Smiciklas et al., 2008). There is a lack of research investigating the ability of cover crops ability to interact with fall applied $\mathrm{N}$ management system in the Midwest corn- 
belt. In the Mississippi delta, Adeli et al. (2001) reported that when broiler litter was fall applied directly into a cereal rye stand, a $57 \%$ decrease in $\mathrm{NO}_{3}{ }^{-} \mathrm{N}$ was observed at a depth of $60 \mathrm{~cm}$ in the soil profile in the cover crops treatments relative to non-cover crop treatments. According to a study conducted by Lacey and Armstrong (2013), cover crops have the capacity to reduce distribution of inorganic nitrogen within the soil profile in a silage cropping system in a fall only $\mathrm{N}$ application system. Therefore, the proposed objectives of this study are to determine the ability of cover crops to reduce TIN concentrations of the soil profile in both spring dominated and fall dominated $\mathrm{N}$ management systems in a corn-soybean cropping system. The Illinois Nutrient Loss Reduction Strategy is calling for a $15 \%$ reduction in $\mathrm{NO}_{3}-\mathrm{N}$, and has outlined reductions in $\mathrm{N}$ losses in with spring applied $\mathrm{N}$ and cover crops. Due to the widespread use of fall applied $\mathrm{N}$ fertilizer, this goal cannot be achieved unless all the efficacy of nitrogen management systems are improved and cover crops are one of the effective tool in doing this.

\section{Materials and Methods}

\section{Site Description}

The experimental site was located east of Lexington, Illinois (SE 1/4 of NW 1/4 of sec. 11 T25N R4E of the $3^{\text {rd }}$ P.M.) at the Illinois State University Nitrogen Management Research Field Station. The predominant soil types within the site are Drummer and El Paso (67.5\%) and Hartsburg (26\%) silty clay loams, both soil types are common in the central Illinois region. Both soils are classified as poorly drained with a 0-2\% slope (typical of Midwestern soils that require tile drainage). The production history of this field consists of an eight year rotation of strip-tilled corn (Zea mays L.) and no-till soybeans (Glycine max L.), which were both harvested for grain. The site was comprised of fifteen individually drained 0.648ha plots. Tile was installed on April $18^{\text {th }} 2014$ and three $7.6 \mathrm{~cm}$ tile laterals spaced $13.7 \mathrm{~m}$ apart were installed in each plot. The 
laterals join together $4.5 \mathrm{~m}$ from a controlled drainage structure before connecting to $15.2 \mathrm{~cm}$ main tile (Figure 1). This lateral spacing was selected because it is an accepted spacing for proper drainage in the poorly drained soils native to this area. Fifteen centimeter inside diameter interceptor tiles were placed around the boarders of each replications to prevent movement of ground water between replication and to prevent ground water from entering from outside the boarder of the plots. The tile main from the research site drains into Patton Creek, which drains into the Mackinaw River that drains into the Illinois River, which contributes to the Mississippi River. This site consisted of five treatments replicated three times in a randomized block design. The $\mathrm{N}$ rate chosen for this study was the suggested MRTN (Maximum return to Nitrogen) of 224 $\mathrm{kg} \mathrm{N} \mathrm{ha}^{-1}$ for central Illinois developed by the $\mathrm{N}$ rate calculator (Iowa State University). 


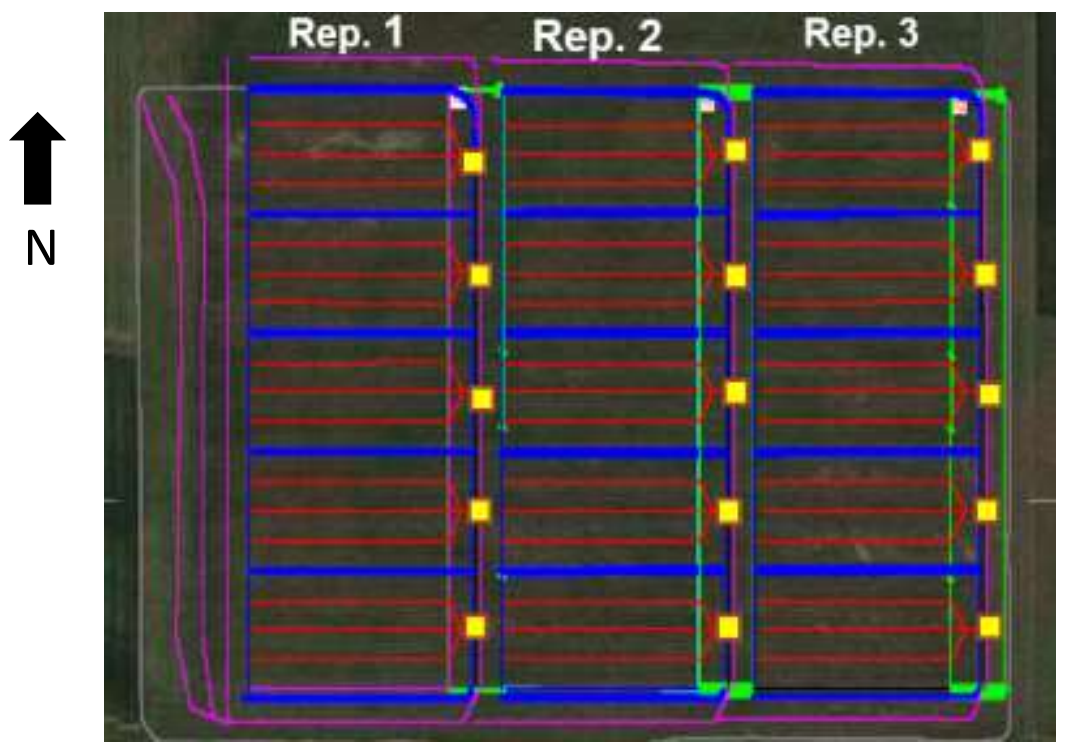

Figure 1. Tiling system of research site. Purple lines represent interceptor tiles to prevent water movement into and between replications. Red lines represent $13.7 \mathrm{~m}$ tile laterals within each plot. The yellow boxes represent a controlled drainage structure with a tile monitoring station. 
This study analyzed the following $\mathrm{N}$ management treatments:

I. Zero Control-No fertilizer and no cover crop

II. Spring dominated split application of nitrogen (SN): 20\% fall- DAP; $80 \%$ springsidedress anhydrous ammonium

III. Spring dominated split application of nitrogen + cover crops (SNCC): 20\% fallDAP; $80 \%$ spring- sidedress anhydrous ammonium

IV. Fall dominated split application of nitrogen (FN): 70\% fall- anhydrous ammonium and DAP; 30\% spring- sidedress anhydrous ammonium

V. Fall dominated split application of nitrogen + cover crops (FNCC): 70\% fallanhydrous ammonium and DAP and $30 \%$ spring sidedress anhydrous ammonium Each treatment was randomly assigned within each of the three blocks and planted in the same plots throughout the course of the study. The cover crop mixture selected for this study was a 92\% cereal rye (Secale cereal L.) and 8\% daikon radish (Raphanus sativus L.) mixture seeded at $84.1 \mathrm{~kg} \mathrm{ha}^{-1}$. A cereal rye and daikon radish cover crop mixture is common in this area and both species are excellent at scavenging $\mathrm{N}$ from the soil. Daikon radish is winter terminated, but cereal rye is winter hardy, which will provide soil cover in the spring that can further stabilize $\mathrm{N}$ mineralized from the winter terminated daikon radish along with any residual $\mathrm{N}$ or $\mathrm{N}$ from fertilizer applied in the fall. The cereal rye was chemically terminated with a Roundup Powermax (active ingredient glyphosate) 2-3 week before the anticipated planting date of the cash crop. 


\section{Cultural Practices}

All field practices and applications are designed to follow common agricultural practices in the Midwest and were influenced by the farmer participating in this study (Figure 3). A cornsoybean cropping system rotation was used for this study. Both the corn and soybeans were planted in $76.2 \mathrm{~cm}$ rows with the target planting rate for corn at 79,100 seeds per hectare and for soybeans at 344,400 seeds per hectare. The planting and harvest dates of the cash crops varied year-to-year dependent on the weather. All treatments, except the Zero Control, received a total of $224 \mathrm{~kg} \mathrm{~N} \mathrm{ha}^{-1}$ for the corn cash crop. The $\mathrm{N}$ source used in the fall and spring was anhydrous ammonia, which is commonly used by farmers in the region. The $\mathrm{N}$ management strategy was to apply a total rate of approximately $224 \mathrm{~kg} \mathrm{~N} \mathrm{ha}^{-1}$ across various timings of $\mathrm{N}$ application. The treatments that received the dominated portion of the applied fertilizer $\mathrm{N}$ in the fall received $80 \%$ of the total $\mathrm{N}$ in the fall and $20 \%$ in the spring and the dominantly spring applied treatments received $30 \%$ of the total $\mathrm{N}$ rate in the fall and $70 \%$ in the spring. While the spring $\mathrm{N}$ management system did not receive fall anhydrous ammonium, the tool bar was ran through the plots when the anhydrous ammonium for the fall systems was applied to create the tillage strips for the planting of the corn in the following spring. All fall anhydrous ammonium was applied with a nitrogen inhibitor (N-Serve). Spring application of $\mathrm{N}$ was applied as a sidedress using anhydrous ammonium without $\mathrm{N}$-serve in the beginning of June.

Cover crops (cereal rye and daikon radish mixture) were seeded into the standing cash crop at a rate of $84.1 \mathrm{~kg} \mathrm{ha}^{-1}$ using a high-rise planter in early to mid-September (Figure 2). Throughout the duration of the study, daikon radish plants winter terminated 2-4 months after planting from subfreezing temperatures and vegetative desiccation. In mid-April, chemical termination of the cereal rye was accomplished using a non-selective herbicide (Glyphosate and 
2, 4-Dichlorophenoxyacetic acid) at least two weeks before the anticipated planting of the cash crop.

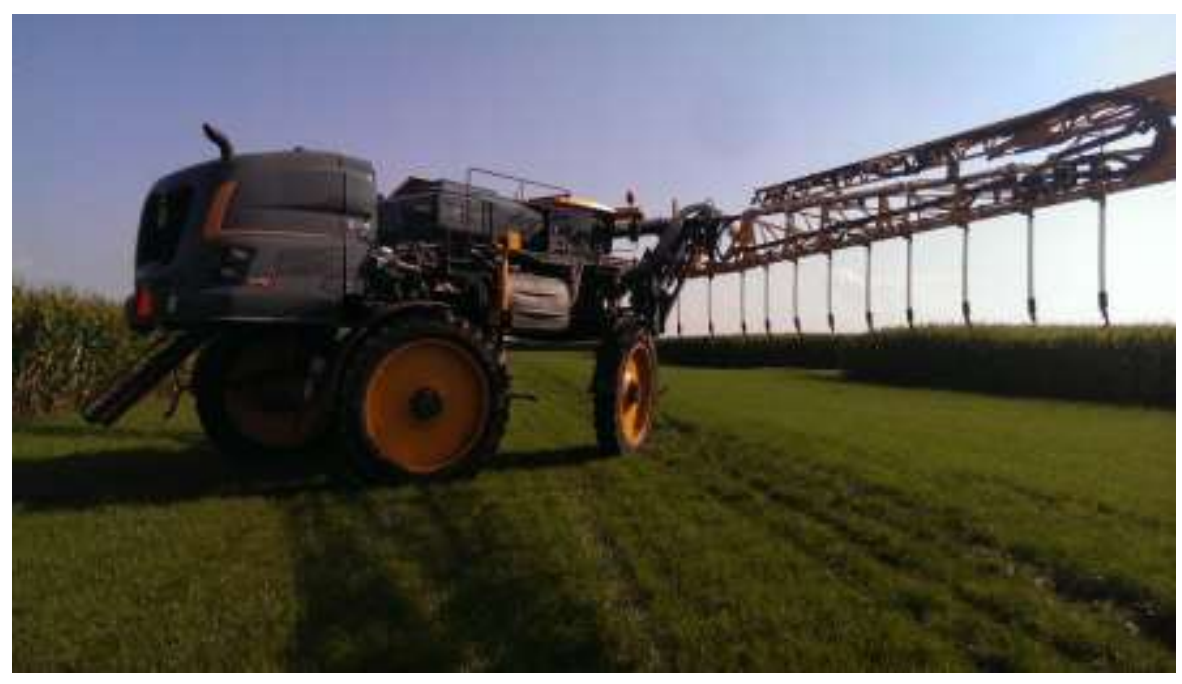

Figure 2. Hagie STS modified with air seeder used to plant cover crops.

\section{Soil Sampling}

Soil samples were collected in the spring closely following the chemical termination of the cereal rye. To accurately determine the impact of cover crops on the distribution of plant available $\mathrm{N}$ within the soil profile, soil samples were collected to a depth of $80 \mathrm{~cm}$ and divided into four segments $(0-5 \mathrm{~cm}, 5-20 \mathrm{~cm}, 20-50 \mathrm{~cm}, 50-80 \mathrm{~cm})$. The agronomic depths $(0-5 \mathrm{~cm}$ and $5-$ $20 \mathrm{~cm})$ will represent the $\mathrm{N}$ accessible to the plant and the environmental depth $(20-50 \mathrm{~cm}$ and 50 $80 \mathrm{~cm}$ ) will represent the $\mathrm{N}$ that is more susceptible to leaching through the soil profile and 
leaving the field via tile drainage before uptake from the cash crop can occur. The soil cores were randomly collected within each treatment using a hydraulically driven probe. The soil samples were then immediately oven dried at $60^{\circ} \mathrm{C}$ for 72 hours and then ground down to pass through a 1-mm sieve for analysis. Soil temperature and moisture was collected at the time of sampling as supplementary data from three separate locations in order to accurately portray the average within each plot. A calcium chloride $\left(\mathrm{CaCl}_{2}\right)$ extraction procedure was used with a 50 $\mathrm{mL} 0.01 \mathrm{M} \mathrm{CaCl}_{2}$ solution and $5.0 \mathrm{~g}$ of dried and ground sample. The samples were then placed on a shaker table for 30 minutes at 200 revolutions per minute (RPMs). After shaking, the solution and solids were separated by placing the samples in a centrifuge set at 1500 RPMs for 5 minutes. After separation, the solution was filtered through \#42 Whatman filter paper to remove any remaining particulates. The extractant was calorimetrically analyzed with a LACHAT flow injection analysis auto sampler for $\mathrm{NO}_{3}-\mathrm{N}$ and ammonium $\left(\mathrm{NH}_{4}\right)$

\section{Plant Sampling}

Cover crops were sampled for above ground biomass and $\mathrm{N}$ uptake in the fall prior to the winter termination of the daikon radish and in the spring before chemical termination of the cereal rye. Within each cover crop plot, four $0.6858 \mathrm{~m}^{2}$ quadrant samples were randomly selected and the above ground biomass was harvested to make a composite sample. This sampling method was modified from the method developed be Dean and Weil (2009). The cover crop samples were over dried at $60^{\circ} \mathrm{C}$, weighed to determine the dry weight, and ground to pass through a $1 \mathrm{~mm}$ sieve. Total percent $\mathrm{N}$ was determined with a Flash $2000 \mathrm{NC}$ using a dry combustion method. Nitrogen uptake was calculated by multiplying the percent $\mathrm{N}$ by the dried biomass weight of the plot. 


\section{Grain Yield Sampling}

Cash crop grain yield and moisture data was collected during the harvest of each plot.

Grain yield were determined with a weigh wagon following the harvest of a measured area. A subsample of each plot was collected to determine the moisture of the grain. The weight of the grain is standardized to $15 \%$ moisture for the corn, and $13 \%$ for soybeans. These measurements were used to determine the cash crop grain yield on a per hectare basis. 


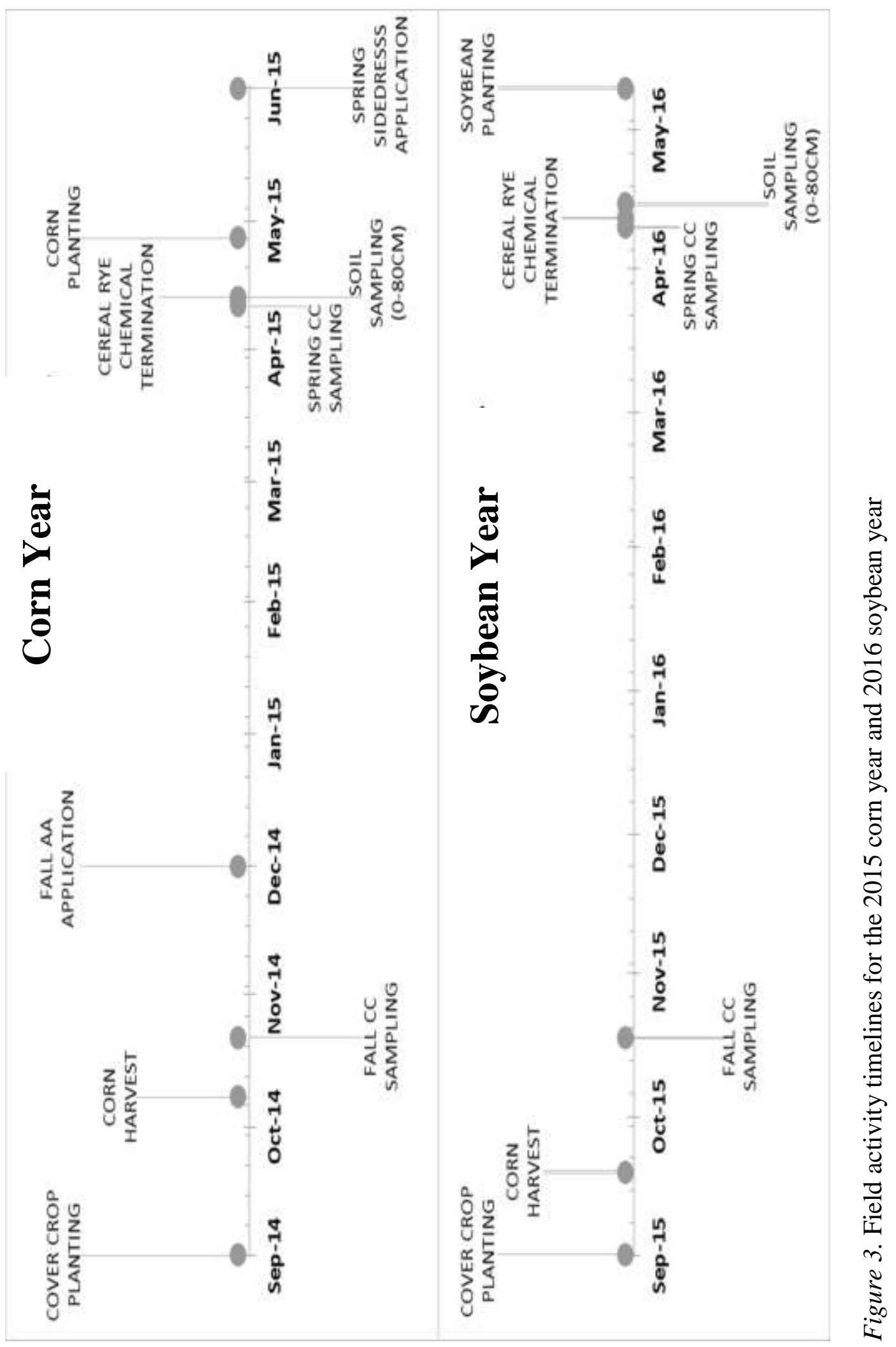




\section{Statistical Analysis}

All data was analyzed using a randomized block analysis of variance test (ANOVA) at an alpha level of $\alpha=0.05$ procedure in SAS 9.3. If the analysis of variance (ANOVA) indicated a significant difference, then a Ryan's procedure test was used to separate the means. The results was presented as a means and standard errors.

\section{Results}

\section{Environmental Conditions}

To understand the impact of weather on cover crop growth and $\mathrm{N}$ sequestration, ambient air temperature and total precipitation were recorded over the course of the study (Table A-1). The average ambient air temperature for the 2014 cover crop season (September 2014- April 2015) was in general lower than the regional 30-year average with September, November, February, and March $1.1,4.3,6.1$, and $1.9^{\circ} \mathrm{C}$ cooler than the regional 30-year average, respectively. The average ambient air temperature for the 2015 corn season (May-September) was comparable to the regional 30 -year average, averaging only $0.2^{\circ} \mathrm{C}$ cooler. The 2015 cover crop season (September 2015- April 2016) was generally warmer than the regional 30-year average. The monthly ambient air temperatures of September, November, December, February, and March were 1.5, 2.1, 6.0, 1.8, and 3.4 degrees warmer than the regional 30-year average, respectively. During the 2016 soybean season (May-October), the air temperature stayed comparable to the 30 -year regional average.

The total precipitation for the 2014 cover crop growing was considerably lower than the regional 30-year average with $401.1 \mathrm{~mm}$ of precipitation, compared to the regional 30-year average of 571.7mm. Average precipitation in November 2014 through April of 2015 ranged from $17.7 \mathrm{~mm}$ to $41 \mathrm{~mm}$. below the 30 -year average. The 2015 corn season had considerably 
higher rainfall when compared to the regional 30-year average with May, June, July, and August resulting in $23.5,78.5,40.9$, and $9.9 \mathrm{~mm}$ more rainfall compared to the 30 -year average, respectively. Record rainfall totals were documented in central Illinois during the June of 2015 with our research plots totaling $179 \mathrm{~mm}$ while the regional 30 -year average is $100 \mathrm{~mm}$. While there was little difference in total precipitation for the 2015 cover crop season, two of the eight months had considerably more precipitation compared to the regional 30-year average. November and December of 2015 had 22 and 99mm greater precipitation compared to the regional 30-year average, respectively. In the 2016 soybean season, the precipitation total in May and June were similar to the 30-year average; however, July and August totaled 58.7 and $59.2 \mathrm{~mm}$ greater than the 30 -year regional average, respectively.

\section{Cover Crop Dry Matter and Nitrogen Uptake}

The 2014 cover crop season preceded a corn cash crop; therefore, the cover crops had the potential to interact with the fertilizer applied in the fall. In the fall of 2014, the cereal rye and daikon radish in the fall with cover crop treatment (FNCC) and spring with cover crop (SNCC) treatment accumulated a total dry biomass of 332.2 and $265.2 \mathrm{~kg} \mathrm{ha}^{-1}$ and a total $\mathrm{N}$ uptake of 12.3 and $10.9 \mathrm{~kg} \mathrm{ha}^{-1}$, respectively. The daikon radishes in the cover crop mixture were winter killed in late-November to mid-December as a result of colder than average air temperatures in September, October, and November. The remaining cereal rye was sampled before chemical termination in the spring. Compared to the total fall biomass, the remaining spring biomass of the cereal rye in the FNCC and SNCC treatments resulted in a significantly greater biomass and $\mathrm{N}$ uptake with $1,179.6$ and $1033.7 \mathrm{~kg} \mathrm{ha}^{-1}$ of biomass and a total $\mathrm{N}$ uptake of 61.5 and $45.6 \mathrm{~kg} \mathrm{~N}$ ha $^{-1}$ of total N uptake, respectively (Table A-2; Table A-3; Table A-4). 
The 2015 cover crop season preceded a soybean cash crop, so no fertilizer was applied. In contrast to the previous cover crop season, the cover crops only had the potential to interact with naturally mineralized $\mathrm{N}$ and residual $\mathrm{N}$ from the corn season. In the fall of 2015 , the cereal rye and daikon radish in the FNCC and SNCC treatments accumulated a total biomass of 1,375.4 and $1459.1 \mathrm{~kg} \mathrm{ha}^{-1}$ and absorbed 54.9 and $63.9 \mathrm{~kg} \mathrm{~N}^{\text {ha-1 }}$, respectively. Above average air temps in September, October, November, and December resulted in a later winter termination of the daikon radish in late-December to late January, which contributed to significantly greater biomass production and $\mathrm{N}$ uptake compared to the 2014 fall biomass sampling (Table A-2; Table A-3; Table A-4). After the senescence of daikon radish in the winter, the remaining cereal rye was sampled before chemical termination in the spring. The FNCC and SNCC treatments resulted in a biomass of $1,072.7$ and $1,373.8 \mathrm{~kg} \mathrm{ha}^{-1}$ and a total $\mathrm{N}$ uptake of 29.0 and $33.7 \mathrm{~kg} \mathrm{~N}$ $\mathrm{ha}^{-1}$, respectively. The $\mathrm{N}$ uptake was significantly less in the 2015 spring sampling compared to the 2014 spring sampling for both treatments (Table A-2; Table A-3; Table A-4).

\section{Cash Crop Yields}

For the 2015 corn crop, yields were determined from 24 rows, measured using a weigh wagon, and adjusted to $15.5 \%$ moisture content (Table A-6). No significant difference was observed between the FN and FNCC treatments, which yielded 12.83 and $12.82 \mathrm{Mg} \mathrm{ha}^{-1}$, respectively (Table A-5). A significant decrease was observed with the addition of cover crops within the spring nitrogen management system, with the SN and SNCC yielding 13.27 and $12.35 \mathrm{Mg} \mathrm{ha}^{-1}$, respectively. No significant differences were observed between the SN and FN treatments or the FNCC and SNCC treatments. A significant difference was observed between all of the treatments that received $\mathrm{N}$ relative to the Zero Control, which yielded $4.62 \mathrm{Mg} \mathrm{ha}^{-1}$. In the 2016 
soybean cash crop, there were no significant difference in yield for any of the treatments (Table A-6).

\section{Cover Crop Impact on Soil TIN Distribution}

In the spring of 2015, both the SNCC and the FNCC significantly reduced the amount of TIN within the soil profile when compared to the FN (Table A-7; Table A-11). The SNCC and the FNCC treatments also significantly reduced the total amount of $\mathrm{NH}_{4}$ within the soil profile when compared to the SN and the FN treatments (Table A-10).

No significant differences were observed between treatments at any of the depths in the spring of 2015 for $\mathrm{NO}_{3}-\mathrm{N}, \mathrm{NH}_{4}$, or TIN; but, a general trend emerged (Table A-9; Table A-10; Table A-11) The SNCC and FNCC treatments had less TIN at each of the depths when compared to the FN and SN treatments (Figure A-1). A similar trend was observed when $\mathrm{NO}_{3}-\mathrm{N}$ at each depth for FNCC and SNCC was compared to the SN and FN treatment (Figure A-2). Despite no significant difference, the SN, SNCC, and FNCC treatments had less $\mathrm{NH}_{4}$ compared to the FN at the $0-5 \mathrm{~cm}, 5-20 \mathrm{~cm}$, and $20-50 \mathrm{~cm}$ depths (Figure A-3).

In the spring of 2016, a significant reduction in the total amount of $\mathrm{NO}_{3}-\mathrm{N}$ within the soil profile was observed in the SNCC and FNCC treatment compared to the SN, FN, and the Zero Control. No significant differences were observed between treatments in the total amount of $\mathrm{NH}_{4}$ or TIN within the soil profile (Table A-8; Table A-12; Table A-13; Table A-14).

More specifically in the spring of 2016, while there were no significant differences in the amount of $\mathrm{NO}_{3}-\mathrm{N}$ and TIN at the upper depths of the soil profile, there were significant differences at the lower depths (Table A-12; Table A-14). At the 20-50cm depth, both the FNCC and SNCC treatments significantly decreased the amount of $\mathrm{NO}_{3}-\mathrm{N}$ compared to the $\mathrm{SN}$, Zero 
Control, and FN (Figure A-5). At the 50-80cm depth, there was significantly less $\mathrm{NO}_{3}-\mathrm{N}$ in the FNCC and the SNCC when compared to the SN and the FN. In addition, there was also significantly less $\mathrm{NO}_{3}-\mathrm{N}$ in the Zero Control compared to the $\mathrm{FN}$ at the $50-80 \mathrm{~cm}$ depth. Analysis for TIN at the $20-50 \mathrm{~cm}$ depth showed significantly less TIN in the FNCC and the SNCC compared to the SN Zero Control and FN treatments (Table A-14; Figure A-4). In the 50-80cm region of the soil there was also significantly less TIN in the SN treatment when compared to the FN. At the $50-80 \mathrm{~cm}$ depth, there was significantly less TIN in the FNCC, SNCC, and the Zero Control compared to the FN. The SNCC treatment also had significantly less TIN compared to the SN. No significant differences were observed between the FN and SN treatments at the 50$80 \mathrm{~cm}$ depth. No significant differences were observed at any depth for $\mathrm{NH}_{4}$ concentration between treatments (Table A-13; Figure A-6).

\section{Discussion}

The impact of cover crops on the distribution of soil inorganic $\mathrm{N}$ was evaluated across two distinctly different weather conditions including differences for the 2014 and 2015 CC seasons. The $2014 \mathrm{CC}$ season ambient air temperature was generally lower than the 30 year average with November averaging $4.3^{\circ} \mathrm{C}$ below and the precipitation totals were $30 \%$ less relative to the 30 year average. The $2015 \mathrm{CC}$ season experienced considerably warmer average ambient air temperatures relative to the 30 year average, with December averaging $5.8^{\circ} \mathrm{C}$ above and above average precipitation in November and December relative to the 30 year average. These differences in air temperature and total precipitation had a clear impact on biomass production, the winter termination date of the daikon radish, and $\mathrm{N}$ uptake of the cover crops between years. The colder air temperature in the $2014 \mathrm{CC}$ season resulted in poor growth of the daikon radish in the fall and a much earlier termination date when compared to the $2015 \mathrm{CC}$ 
season, which was considerably warmer. In the $2014 \mathrm{CC}$ season, we observed 3 to 3.5 months of growth for the daikon radish, which was less than the 4-4.5 months of growth observed in the $2015 \mathrm{CC}$ season. The combination of below average air temperature and below average precipitation in the $2014 \mathrm{CC}$ season resulted in a significant reduction of $75 \%$ less biomass production and $\mathrm{N}$ uptake at the fall sampling relative to the $2015 \mathrm{CC}$ season. In 2014 , although unfavorable weather conditions during the $\mathrm{CC}$ season resulted in poor biomass production and $\mathrm{N}$ uptake from the radish and cereal rye mixture in the fall, there was considerable biomass and $\mathrm{N}$ uptake from the cereal rye in the spring. The drastic difference in biomass and $\mathrm{N}$ uptake can be attributed to the winter hardiness of the cereal rye, the spring warm up, and a possible relay of $\mathrm{N}$ from the decomposing radish to the vigorously growing cereal rye. These results demonstrate the security of planting a cover crop mixture that provides aggressive fall and spring growth. In the 2015 CC season, above average ambient air temperature and precipitation in the fall and early winter resulted in greater growth of the daikon radish due to a longer growing period from planting to the killing frost. In addition, while the biomass of the cereal rye in the spring of the 2015 CC season was comparable to the values in the spring of the 2014 CC season, we observed considerably less $\mathrm{N}$ uptake from cereal rye in the $2015 \mathrm{CC}$ season. This reduction in $\mathrm{N}$ uptake with no reduction of biomass production could be a result of drastically lower soil TIN in the spring of 2016 relative to the spring of 2015. Several factors contributed to lower soil TIN values in the spring of 2016. The first factor is the 2015 CC season preceded a soybean cash crop so no $\mathrm{N}$ fertilizer was applied; as a result, the TIN in the soil was drastically lower in the 2015 spring soil sampling relative to the 2016 spring soil sampling. Secondly, the warm winter of 2015 with excessive amounts of rainfall in November and December provided ideal condition for $\mathrm{N}$ losses from the soil through leaching and denitrification. As a result, in a cover crop 
season with weather condition that are ideal for losses of any residual $\mathrm{NO}_{3}-\mathrm{N}$ and with no addition of fertilizers to resupply the pool of inorganic $\mathrm{N}$, we observed a substantial reduction in the $\mathrm{N}$ uptake of the cover crop.

The 2014 cover crop season preceded a corn cash crop, so cover crop biomass and $\mathrm{N}$ uptake were evaluated between the two different $\mathrm{N}$ fertilizer application systems used in this study (see treatments mentioned previously). In the 2014 CC season, the FNCC treatment yielded a greater biomass and $\mathrm{N}$ uptake at both the fall and spring sampling dates relative to the SNCC treatment. This is likely due to the fact that the cover crops in the FNCC treatment not only interacted with naturally mineralized $\mathrm{N}$ and residual $\mathrm{N}$, but the cereal rye also had the opportunity to interact with the fall applied anhydrous ammonia. In comparison, the cover crop in the SNCC treatment could only interact with the naturally mineralized $\mathrm{N}$ and residual $\mathrm{N}$. The 2015 CC season preceded a soybean cash crop so no fertilizer was applied. At both the fall and spring cover crop sampling dates, the cover crops in the SNCC treatment yielded a higher biomass production and $\mathrm{N}$ uptake compared to the FNCC treatment. This is likely a consequence of a larger portion of $\mathrm{N}$ fertilizer in this treatment applied as sidedress mid-summer, potentially resulting in a larger residual pool of nitrogen. According to the observed differences in biomass production and $\mathrm{N}$ uptake by both cover crops in the mixture in response to climatic differences, we noted that the fall growth of radish is dominant during warmer falls and cereal rye growth excels in cold falls and warm springs. This observation demonstrates the synergy and added security of an impactful cover crop stand including multiple species.

In comparison to others' research, the integration of cover crops has dominantly been in spring $\mathrm{N}$ application systems, where the purpose of the cover crops were to interact with residual N from the previous cash crop season or naturally mineralized N (Ranells and Wagger, 1997; 
McCracken et al., 1994). According to others' published research, cover crop N uptake in a spring $\mathrm{N}$ fertilizer application system ranged from $37-83 \mathrm{~kg} \mathrm{~N} \mathrm{ha}^{-1}$ for cereal rye in Maryland (Dean and Weil, 2009) and 9-76 kg N ha-1 for cereal rye in a four year study in Iowa (Kasper et al., 2007). In the FNCC treatment of our study, $70 \%$ of the $\mathrm{N}$ was fall applied so there is a great possibility that cover crops interacted with a portion of the $\mathrm{N}$ fertilizer applied in the fall.

Despite dynamic weather conditions between the two cover crop seasons, the cover crops in both the SNCC and FNCC treatments demonstrated the ability to sequester an average of 39 and 45 $\mathrm{kg} \mathrm{N} \mathrm{ha}{ }^{-1}$, respectively, at the time of chemical termination in the spring. This observation demonstrates that over the two years of this study, the cover crops sequestered on average of $30 \%$ of the total amount of $\mathrm{N}$ fertilizer applied in the fall treatment and $100 \%$ of fall $\mathrm{N}$ as DAP in our spring system. This is comparable to Kasper et al. (2007) which showed that when cereal rye is used in a corn-soybean rotation with all of the $\mathrm{N}$ fertilizer applied as sidedress with urea, the cereal rye on average sequestered $47.5 \mathrm{~kg} \mathrm{~N} \mathrm{ha}^{-1}$, averaging an uptake of about $20 \%$ of the total $\mathrm{N}$ fertilizer applied over the four years of the study.

In the spring of 2015 at the termination of the cover crops, we recorded a 41 and $35 \%$ reduction in TIN in the soil profile $(0-80 \mathrm{~cm})$ with the inclusion of cover crops in the fall and spring systems, respectively. While not significant due to variability across the field, there was a $51 \%$ reduction of $\mathrm{NO}_{3}-\mathrm{N}$ within the soil profile in the fall system with the addition of $\mathrm{CC}$ and a $47 \%$ reduction in the spring system. A similar trend was observed in $\mathrm{NO}_{3}-\mathrm{N}$ distribution within the agronomic region of the soil profile $(0.20 \mathrm{~cm})$ when the cover crop were introduced, with a $62 \%$ reduction in the fall $\mathrm{N}$ system and $50 \%$ reduction in the spring $\mathrm{N}$ system. The addition of cover crops also reduced the amount of $\mathrm{NO}_{3}-\mathrm{N}$ within the environmental depth $(20-80 \mathrm{~cm})$ of the soil profile by $17 \%$ in the fall system and $37 \%$ in the spring system. This reduction in soil $\mathrm{NO}_{3}-$ 
$\mathrm{N}$ can be attributed to the ability of the cover crops to absorb residual, mineralized, and fall applied N, reducing its vulnerability to leaching and denitrification. Similar results were observed in a study conducted by Lacey and Armstrong (2013). They determined that fall applying $\mathrm{N}$ without cover crops resulted in a greater percentage of soil $\mathrm{NO}_{3}-\mathrm{N}(40 \%)$ in the 50 to $80-\mathrm{cm}$ depth of the soil profile, compared with only 31 and $27 \%$ when tillage radish and cereal rye were present at $\mathrm{N}$ application. By altering the distribution of inorganic $\mathrm{N}$ and reducing the amount of TIN lower in the soil profile next to the tile drain, the TIN is less susceptible to loss. This could be a result of a biological impact from $\mathrm{N}$ uptake of the cover crops or a physical impact due to cover crops reducing soil moisture from transpiration and increasing the matric potential of the soil making downward movement of water and nutrients more difficult. According to Kuykendall et al. (2015), having cover crops present significantly reduces the water content of the soil profile down to a depth of $2.74 \mathrm{~m}$. This observation is significant considering the fact that in some regions of the Upper Mississippi River basin, 40-75\% of farmers still fall apply a portion of their N fertilizer (EPA, 2007; Ribaudo et al., 2012; Smiciklas et al., 2008). The extensive tile drainage within the region coupled with fall application of $\mathrm{N}$ drastically increase the potential for nitrate leaching; consequently, in order to meet the Illinois Nutrient loss Reduction Strategy's goal of a $15 \%$ reduction in N loading by 2025 , there is a need to make fall applications of $\mathrm{N}$ more efficient. This study shows that cover crops have the ability to significantly reduce the amount of TIN within the soil profile susceptible to loss by leaching in both spring and fall $\mathrm{N}$ fertilizer application systems. Adeli et al., 2001, documented similar results in the Mississippi River Basin, where broiler litter applied in the fall to a cereal rye cover crops resulted in a 57\% decrease in nitrate leaching at a depth of $60 \mathrm{~cm}$ compared to a non-cover crop treatment. This study in conjunction with other studies in the literature show that cover 
crops used as a tool to reduce the susceptibility of $\mathrm{NO}_{3}-\mathrm{N}$ losses from $\mathrm{N}$ fertilizers can be utilized not only in Illinois, but in other states in the Midwest that rely on fertilizers and manures for agricultural production systems.

A $23 \%$ reduction in $\mathrm{NH}_{4}$ within the soil profile was observed with the inclusion of cover crops in the fall system, but no reduction was observed in the spring system. Since the fall treatment received $100 \mathrm{~kg} \mathrm{~N} \mathrm{ha}^{-1}$ in the fall as $\mathrm{AA}$, a larger pool of $\mathrm{NH}_{4}$ was available for the cereal rye to interact with in the following spring. This can be confirmed by comparing the impact of $\mathrm{N}$ application timing on the $\mathrm{NH}_{4}$ concentration within the soil profile, in which a $27 \%$ reduction is observed in the $\mathrm{SN}$ treatment relative to the FN. The inclusion of cover crops in the fall system resulted in a $20 \%$ reduction in $\mathrm{NH}_{4}$ found in the agronomic region of the soil profile and a 34\% reduction in the environmental region; whereas, no significant reduction was observed in the spring system in either of the regions. While $\mathrm{NH}_{4}$ is stable within the soil profile and not a major contributor to the nutrient load of sub surface drainage, this study has shown that cover crops have to potential to interact with fall applied fertilizer and stabilize a substantial portion of the $\mathrm{NH}_{4}$ present in the soil.

The soybean cash crop produced in 2016 gave us the opportunity to determine the impact of cover crops in a year when no $\mathrm{N}$ fertilizer was applied. When compared to the previous year, the average TIN across treatments within the soil profile in the spring of 2016 was significantly lower compared to the 2015 concentration. This could be a result having no fertilizer applied, increased denitrification and leaching due to above average ambient air temperature and precipitation, and a considerable amount of cover crop biomass and $\mathrm{N}$ uptake in the fall and spring. A $22 \%$ and $24 \%$ reduction in TIN within the soil profile was observed with the addition of $\mathrm{CC}$ in the fall and spring systems, respectively. When the $\mathrm{NH}_{4}$ values from the spring of 2016 
were examined, no major trends or difference were observed; however, there was a $33 \%$ reduction in $\mathrm{NO}_{3}-\mathrm{N}$ within the soil profile with the addition of $\mathrm{CC}$ in the fall system and a $53 \%$ reduction in the spring system. When the agronomic and environmental regions were examined, a $40 \%$ reduction of $\mathrm{NO}_{3}-\mathrm{N}$ in the agronomic region of the soil was observed with the inclusion of $\mathrm{CC}$ in the spring system but no differences were observed in the fall system. At the environmental depth of the profile, a $69 \%$ and $67 \%$ reduction in $\mathrm{NO}_{3}-\mathrm{N}$ was observed with the addition of $\mathrm{CC}$ in the fall and spring systems, respectively. In a four-year study done by Kasper et al. (2007) in Iowa, the inclusion of cover crops resulted in a significant reduction in TIN in after harvest soil samples. They also observed in some years, the $\mathrm{NO}_{3}-\mathrm{N}$ concentration in the subsurface drainage could be greater in the soybean phase of a corn-soybean rotation relative to the corn phase.

\section{Conclusion}

This study indicates that in both spring applied $\mathrm{N}$ fertilizer and fall applied $\mathrm{N}$ fertilizer management systems, cover crops have the potential to significantly reduce the amount of inorganic $\mathrm{N}$ within the soil profile; thus, reducing its susceptibility to leaching. When the majority of the $\mathrm{N}$ fertilizer is applied in the fall, the inclusion of cover crops reduced the total amount of $\mathrm{NO}_{3}-\mathrm{N}$ that leaches down to the environmental region of the soil profile by $33-51 \%$ at the time of chemical termination of the cereal rye in the spring. This reduction in soil $\mathrm{NO}_{3}-\mathrm{N}$ can be attributed to the ability of the cover crops to absorb residual, mineralized, and fall applied $\mathrm{N}$, reducing its vulnerability to leaching and denitrification. We determined that cover crops have the potential to sequester $39-61 \mathrm{~kg} \mathrm{~N} \mathrm{ha}^{-1}$ by the time of chemical termination of the cereal rye in the spring. There is dearth of knowledge on cover crops ability to release $\mathrm{N}$ during the cash crop season, especially the return of fall applied $\mathrm{N}$ from cover crop residue. Therefore, 
research is needed that correlates the timing of $\mathrm{N}$ release with the growth stages of cash crops in both fall and spring $\mathrm{N}$ fertilizer application systems. Additionally, there is little research investigating the impact of cover crops on the distribution of phosphorus within the soil profile. Therefore, research is needed to determine the impact of cover crops on the availability and distribution of phosphorus within the soil profile and its potential for leaching and surface runoff.

Similar to other studies, by moving the $\mathrm{N}$ fertilizer application to the spring we observed $18 \%$ reduction in $\mathrm{NO}_{3}{ }^{-} \mathrm{N}$ losses through the subsurface tile drainage in the corn year; however, we recorded a greater loss from the spring application treatments during the soybean phase of the rotation. This demonstrates the need for additional nutrient management practices in order to reduce nutrient losses from agricultural fields. Despite the drastic weather conditions experienced over the course of this study, the data has demonstrated that the addition of cover crops, in either a fall or spring applied $\mathrm{N}$ fertilizer system, can stabilize a substantial portion of the $\mathrm{N}$ within the soil, and reduce its potential for leaching and denitrification. 


\section{REFERENCES}

"Illinois Nutrient Loss Reduction Strategy." Illinois Nutrient Loss Reduction Strategy.

Environmental Protection Agency, n.d. Web. 25 Mar. 2015.

Adeli, A., H. Twolde, J. Jenkins, and D. Rowe. 2011. Cover Crop Use for managing broiler litter applied in the fall. Agronomy Journal. 103:200-210.

Alexander, R.B., R.A. Smith, and G.E. Schwarz. 1995. The regional transport of point and nonpoint source nitrogen to the Gulf of Mexico. In Proc. Gulf of Mexico Hypoxia Conf., Kenner, LA. 5-6 Dec. 1995. USEPA Publ. 855R97001. USEPA Natl. Cent. For Environ. Publ. and Inf., Washington, DC and Prospects: Economic Research Service, Miscellaneous Publication No. 1455. $170 \mathrm{p}$.

Background Report on Fertilizer Use, Contaminants, and Regulations. Washington, D.C.: National Program Chemicals Division, Office of Pollution Prevention and Toxics, U.S. Environmental Protection Agency, 1999. Jan. 1999. Web. 9 Feb. 2015

Baker, J.L., M.B. David, D.W. Lemke, and D.B. Jaynes. 2008. Understanding nutrient fate and transport, including the importance of hydrology in determining field losses, and potential implications for management systems to reduce those losses. p. 1-17. In Upper Mississippi River Subbasin Hypoxia Nutrient Committee (ed.) Final report: Gulf hypoxia and local water quality concerns workshop. Am. Soc. of Agricultural and Biological Engineers, St. Joseph, MI.

Corn Breeding- Hallauer, Arnel R., "Corn Breeding" (2008). Iowa State Research Farm Progress Reports. Paper 549. http://lib.dr.iastate.edu/farms_reports/549

Dean, J., and R. Weil. 2009. Brassica Cover Crops for Nitrogen Retention in the Mid-Atlantic Coastal Plain. Journal of Environmental Quality. 38:520-528.

Dinnes, D.L., D.L. Karlen, D.B. Jaynes, T.C. Kaspar, J.L. Hatfield, T.S. Colvin, and C.A.Cambardella. 2002. Nitrogen management strategies to reduce nitrate leaching in tile-drained midwestern soils. Agron. J. 94:153-171. doi:10.2134/agronj2002.0153

Goolsby, Donald A., Battaglin, William A., Aulenbach, Brent T., Hooper, Richard P. "Nitrogen Input to the Gulf of Mexico" joenq 2001. 30:329-336. doi:10.2134/jeq2001.302329x

Greenan, C., T. Moorman, T. Parkin, T. Kaspar, and D. Jaynes. 2009. Denitrification in Wood Chip Bioreactors at Different Water Flows. Journal of Environmental Quality. 38:16641671.

Illinois Department of Agriculture. Crop History. Illinois Department of Agriculture, n.d. Web. 03 Feb. 2015. 
Kaspar, T.c., D.b. Jaynes, T.b. Parkin, and T.b. Moorman. "Rye Cover Crop and Gamagrass Strip Effects on NO Concentration and Load in Tile Drainage." Journal of Environment Quality 36.5 (2007): 1503-511. 2007. Web. 23 Feb. 2015.Sugg, Zachary. "Assessing U.S. Farm Drainage: Can GIS Lead to Better Estimates of Subsurface Drainage Extent?" N.p., Aug. 2007. Web. 19 Feb. 2015.

King, K. W., and H. A. Torbert. "Nitrate and Ammonium Losses from Surface-applied Organic and Inorganic Fertilizers." The Journal of Agricultural Science 145.04 (2007): 385.16 Jan. 2007. Web. 9 Feb. 2015.

Kladivko, E. J., J. R. Frankenberger, D. B. Jaynes, D. W. Meek, B. J. Jenkinson, and N. R. Fausey. "Nitrate Leaching to Subsurface Drains as Affected by Drain Spacing and Changes in Crop Production System." Journal of Environment Quality 33.5 (2004): 1803-813. Web.

Kovacic, D., R. Twait, M. Wallace, and J. Bowling. 2006. Use of created wetlands to improve water quality in the Midwest - Lake Bloomington case study. Ecological Engineering. 28:258-270.

Kuykendall, M.; Roozeboom, K.; Kluitenberg, G. J.; and Prasad, P. V. Vara (2015) "Cover Crop Impacts on Soil Water Status," Kansas Agricultural Experiment Station Research Reports: Vol. 1: Iss. 2. http://dx.doi.org/10.4148/2378-5977.1046

Lacey, Corey G., and Shalamar D. Armstrong. "In Field Measurements of Nitrogen Mineralization Following Fall Applications of $\mathrm{N}$ and the Termination of Winter Cover Crops." Air, Soil and Water Research (2013): n. pag. Department of Agriculture, Illinois State University, Normal, IL, USA., 31 Jan. 2013. Web. 27 Feb. 2015.

MR/GMWNTF, 2001, Action plan for reducing, mitigating, and controlling hypoxia in the northern Gulf of Mexico: Washington, D.C., Mississippi river/Gulf of Mexico Watershed Nutrient Task Force, 36 p. Available on line at: http://www.epa.gov/msbasin/taskforce/pdf/actionplan.pdf.

National Academy of Sciences_-National Research Council Academy of Life Sciences. The Health Effects of Nitrate, Nitrite, and N-Nitroso Compounds. Washington DC: National Academy of Sciences Press, 1981.

Rabalais, N.N., R.E. Turner, and W.J. Wiseman. 2002. Gulf of Mexico hypoxia, A.K.A. "The Dead Zone”.Annu. Rev. Ecol. Syst. 33:235-263.

Randall, G., and J. Vetsch.2005. Nitrate Losses in Subsurface Drainage from a corn-soybean rotation as affected by Fall and Spring application of Nitrogen and nitraphyrin. Journal of Environmental Quality. 34:590-597.

Redman, J.C. and S.Q. Allen. 1954. "Some Interrelationships of Economic and Agronomic Concepts." Journal of Farm Economics, 36(1), 13. 
Reeves, D. W. 1994. Cover crops and rotations. pp.125-172. In: J.L. Hatfield and B.A. Stewart (eds.) Crops Residue Management. Advances in Soil Science. Lewis Publishers, Boca Raton, FL.

Renaud, M.L. 1986. Hypoxia in Louisiana coastal waters during 1983: implications for fisheries. Fish. Bull. 84:19-26

Ribaudo, Marc, Michael Livingston, and James Williamson. Nitrogen Management on U.S. Corn Acres, 2001-10, EB-20. U.S. Dept. of Agriculture, Economic Research Service, November 2012.

SAS 2012 Statistical Analysis Systems. Software Version 9.4, SAS Institute Inc., Cary, NC, USA

Scharf, P.C. "Best Management Practices for Nitrogen Fertilizer in Missouri." Nutrient Management. Missouri University Division of Plant Sciences, Aug. 2006. Web. 25 Mar. 2014. <Best Management Practices for Nitrogen - Nutrient Management.htm>.

Smiciklas, K.D., A.S. Moore, and J.C. Adams. 2008. Fertilizer nitrogen practices and nitrate levels in surface water within an Illinois watershed. J. Agron. Educ. 37:14-19

Strock, J. S., P. M. Porter, and M. P. Russelle. "Cover Cropping to Reduce Nitrate Loss through Subsurface Drainage in the Northern U.S. Corn Belt." Journal of Environmental Quality 33.3 (2004): 1010-016. May 2004. Web. 23 Feb. 2015.Adeli, A., H. Twolde, J. Jenkins, and D. Rowe. 2011. Cover Crop Use for managing broiler litter applied in the fall. Agronomy Journal. 103:200-210.

Turner, R.E., and N.N. Rabalais. 1991. Changes in Mississippi River water quality this century. Implications for coastal food webs. Bio Science 41:140-147.

U.S. Department of Agriculture, 1987, Farm drainage in the United States: History, Status 


\title{
CHAPTER IV
}

\section{IMPACT OF COVER CROPS AND NITROGEN APPLICATION TIMING ON NUTRIENT LOADING AND CONCENTRATIONS OF SUBSURFACE TILE DRAINAGE}

\begin{abstract}
It has been estimated that nitrate $\left(\mathrm{NO}_{3}-\mathrm{N}\right)$ leaching from artificially drained agricultural fields in the Upper Mississippi River Basin accounts for approximately $65 \%$ of nitrogen (N) delivered annually to the Gulf of Mexico. Therefore, the objectives of this study were to investigate the impact of fertilizer application timing and cover crops (CC) adoption on the load and concentration of nutrients in subsurface drainage leachate. This experiment was conducted at the Illinois State University Nitrogen Management Research Field Station, in Lexington, Illinois. Treatments included a Zero Control (no N fertilizer and no cover crop), a fall dominated $\mathrm{N}$ application (70\% fall, 30\% spring) with and without $\mathrm{CC}$, and a spring dominated $\mathrm{N}$ application ( $20 \%$ fall, $80 \%$ spring) with and without CC. A total rate of $224 \mathrm{~kg} \mathrm{~N} \mathrm{ha}^{-1}$ was applied to all treatments, except the Zero Control. Automated water samplers (ISCO 6712) were programmed to collect samples that were later analyzed for nitrate, ammonium, and dissolved reactive phosphorus concentrations. Spring cover crop sampling revealed an average above ground biomass of $1,011 \mathrm{~kg} \mathrm{ha}^{-1}$ and an average $\mathrm{N}$ uptake of $39.0 \mathrm{~kg} \mathrm{~N} \mathrm{ha}^{-1}$. Over the course of the study, $\mathrm{CC}$ integration resulted in a 41 and $45 \%$ reduction in tile $\mathrm{NO}_{3}-\mathrm{N}$ load in the fall and spring $\mathrm{N}$ application systems, respectively. Cumulative tile leachate for $\mathrm{NO}_{3}-\mathrm{N}\left(\mathrm{kg} \mathrm{ha}^{-1}\right)$ for the first cover crop year revealed the following treatment trends: Fall N without CC (54.0) > Spring N without CC (44.4) > Fall N with CC (39.2) > Spring N with CC (38.5). The second cover crop year revealed a similar trends; however, the SN treatment lost considerable more than the FN: Spring N without CC (72.3) > Fall N without CC (47.67) > Spring N with CC (26.01)> Fall N
\end{abstract}


with $\mathrm{CC}(20.8)$. The average flow-weighted $\mathrm{NO}_{3}{ }^{-} \mathrm{N}\left(\mathrm{mg} \mathrm{L}^{-1}\right)$ concentrations over the course of the study resulting in the following trend: Fall $\mathrm{N}$ without CC (7.47)>Spring $\mathrm{N}$ without CC (7.28)> Fall N with CC (6.18)>Zero Control (5.67)>Spring N with CC (5.60). The Illinois Nutrient Reduction Strategy presents a target of reducing $\mathrm{NO}_{3}-\mathrm{N}$ losses by $15 \%$ by 2025 . This data demonstrates that $\mathrm{CC}$ have the potential to significantly reduce $\mathrm{NO}_{3}-\mathrm{N}$ losses in both spring and fall dominated $\mathrm{N}$ management systems to meet the goals of the Illinois Nutrient Reduction Strategy. 


\section{Introduction}

A direct link between nitrate $\left(\mathrm{NO}_{3}-\mathrm{N}\right)$ levels in surface water and agricultural tile drainage form the Upper Mississippi River Basin (UMRB) has become a major concern. Nitrate leaching from both spring and fall $\mathrm{N}$ fertilizer applications in agricultural fields is a leading contributor to surface water loading and the hypoxic zone in the Gulf of Mexico (Rabalais et al., 2002). As a result, in 2008 the Environmental Protection Agency (EPA) released a Gulf Hypoxic Zone Action Plan, which required each of the 12 states in the Mississippi River Basin (MRB) to develop a strategy to reduce the amount of nutrients carried in rivers to the Gulf. To reduce nutrients lost from Illinois waters, the Illinois EPA developed the Illinois Nutrient Loss Reduction Strategy. One goal of the strategy was a $45 \%$ reduction in loss of nutrients to the Mississippi River with a $15 \%$ reduction in $\mathrm{NO}_{3}-\mathrm{N}$ by 2025 (EPA, 2015). Therefore, there is a need to develop a nitrogen $(\mathrm{N})$ management system that reduces agricultures contribution while still maintaining current productivity.

Studies have shown that the use of best management practices have the potential to significantly reduce $\mathrm{NO}_{3}-\mathrm{N}$ leaching. Applying $\mathrm{N}$ fertilizer in the spring closer to the period of rapid cash crop uptake, applying the optimal $\mathrm{N}$ rate for a given location, selecting the correct source of $\mathrm{N}$, and the method and placement of the $\mathrm{N}$ fertilizers are all factors that have been proven to reduce $\mathrm{N}$ leaching (Scharf and Lory, 2006); however substantial $\mathrm{NO}_{3}{ }^{-} \mathrm{N}$ losses can even occur in years when no $\mathrm{N}$ fertilizer have been applied (Baker et al., 1975; Dinners et al., 2002). Other $\mathrm{N}$ management practices including the use of artificial wetlands and bioreactors are proven to reduce $\mathrm{NO}_{3}-\mathrm{N}$ concentration from tile water by up to $48 \%$, but these practices capture $\mathrm{NO}_{3}-\mathrm{N}$ leaving the field by promoting denitrification (the conversion of nitrate to nitrogen gas): thus, the $\mathrm{N}$ cannot be used by the cash crop (Kovacic, 2006; Greenan, 2009). Thus, there is a 
need for an $\mathrm{N}$ management tool that not only reduces $\mathrm{NO}_{3}-\mathrm{N}$ loading to surface water, but also increases the efficiency and crop utilization of the $\mathrm{N}$ fertilizer. Cover crops, as a tool to capture residual $\mathrm{N}$ through uptake, has been proven to reduce $\mathrm{NO}_{3}-\mathrm{N}$ leaching. In Mississippi delta, Adeli (2011) reported that cereal rye reduced $\mathrm{NO}_{3}-\mathrm{N}$ leachate levels from fall applied broiler liter to near zero in the winter, fall, and spring. Thomas Kasper et al. (2007), studied the effects of cover crops on tile $\mathrm{NO}_{3}-\mathrm{N}$ leachate in a corn-soybean rotation, sidedress $\mathrm{N}$ fertilizer application in Iowa and determined that a rye cover crop treatment significantly reduced the average annual flow-weighted $\mathrm{NO}_{3}-\mathrm{N}$ concentration of drainage water by $50 \%$ or more compared with the control. Strock et al. (2004) studied the impact of fall established rye cover crops following corn on $\mathrm{NO}_{3}-\mathrm{N}$ leaching in a spring application of urea $\mathrm{N}$ application system and determined that over three years, the cover crops reduced $\mathrm{NO}_{3}-\mathrm{N}$ loss by $13 \%$.

While there has been extensive research on the effects of cover crops on spring applied $\mathrm{N}$ application systems, $40-75 \%$ of farmers still fall apply $\mathrm{N}$ due to easier application timing and reduced costs (EPA, 2007; Ribaudo et al., 2012; Smiciklas et al., 2008). There is a lack of research that investigates the ability of cover crops to reduce $\mathrm{NO}_{3}-\mathrm{N}$ leaching in spring versus fall applied $\mathrm{N}$ in the Midwest corn-belt. It is possible that fall applying $\mathrm{N}$ into a living cover crop stand can reduce $\mathrm{NO}_{3}-\mathrm{N}$ leachate levels comparable to a similar rate of spring applied $\mathrm{N}$. Therefore, the proposed objectives of this study are to determine the ability of cover crops to reduce $\mathrm{NO}_{3}-\mathrm{N}$ leaching in both spring dominated and fall dominated $\mathrm{N}$ management systems. These comparisons will determine if cover crops in a fall or spring $\mathrm{N}$ application system can decrease the impact of applied $\mathrm{N}$ on $\mathrm{NO}_{3}-\mathrm{N}$ leachate; therefore, reducing agricultures impact on the Gulf of Mexico dead zone. The Illinois Nutrient Loss Reduction Strategy is calling for a $15 \%$ reduction in $\mathrm{NO}_{3}-\mathrm{N}$, which would affect not only local water quality but also national water 
quality. However, the goal cannot be achieved unless all nitrogen management systems are improved and cover crop an effective nutrient reduction strategies that can reduce the amount of $\mathrm{N}$ leaving the field via tile drainage.

\section{Materials and Methods}

\section{Site Description}

The experimental site was located east of Lexington, Illinois (SE 1/4 of NW 1/4 of sec. 11 T25N R4E of the $3^{\text {rd }}$ P.M.) at the Illinois State University Nitrogen Management Research Field Station. The predominant soil types within the site are Drummer and El Paso (67.5\%) and Hartsburg (26\%) silty clay loams, both soil types are common in the central Illinois region. Both soils are classified as poorly drained with a 0-2\% slope (typical of Midwestern soils that require tile drainage). The production history of this field consists of an eight year rotation of strip-tilled corn (Zea mays L.) and no-till soybeans (Glycine max L.), which were both harvested for grain. The site was comprised of fifteen individually drained 0.648ha plots. Tile was installed on April $18^{\text {th }} 2014$ and three $7.6 \mathrm{~cm}$ tile laterals spaced $13.7 \mathrm{~m}$ apart were installed in each plot. The laterals join $4.5 \mathrm{~m}$ from a controlled drainage structure before connecting to $15.2 \mathrm{~cm}$ main tile (see Chapter 3, Figure 1). This lateral spacing was selected because it is an accepted spacing for proper drainage in the poorly drained soils native to this area. Fifteen centimeter inside diameter interceptor tiles were placed around the boarders of each replications to prevent movement of ground water between replication and to prevent ground water from entering from outside the boarder of the plots. The tile main from the research site drains into Patton Creek, which drains into the Mackinaw River that drains into the Illinois River, which contributes to the Mississippi River. This site consisted of five treatments replicated three times in a randomized block design. 
The $\mathrm{N}$ rate chosen for this study was the suggested MRTN (Maximum return to Nitrogen) of 224 $\mathrm{kg} \mathrm{N} \mathrm{ha}{ }^{-1}$ for central Illinois developed by the $\mathrm{N}$ rate calculator (Iowa State University).

This study analyzed the following $\mathrm{N}$ management treatments:

I. Zero Control-No fertilizer and no cover crop

II. Spring dominated split application of nitrogen (SN): 20\% fall- DAP; $80 \%$ springsidedress anhydrous ammonium

III. Spring dominated split application of nitrogen + cover crops (SNCC): $20 \%$ fallDAP; 80\% spring- sidedress anhydrous ammonium

IV. Fall dominated split application of nitrogen (FN): $70 \%$ fall- anhydrous ammonium and DAP; 30\% spring- sidedress anhydrous ammonium

V. Fall dominated split application of nitrogen + cover crops (FNCC): 70\% fallanhydrous ammonium and DAP and 30\% spring sidedress anhydrous ammonium

Each treatment was randomly assigned within each of the three blocks and planted in the same plots throughout the course of the study. The cover crop mixture selected for this study was a 92\% cereal rye (Secale cereal L.) and $8 \%$ daikon radish (Raphanus sativus L.) mixture seeded at $84.1 \mathrm{~kg} \mathrm{ha}^{-1}$. A cereal rye and daikon radish cover crop mixture is common in this area and both species are excellent at scavenging $\mathrm{N}$ from the soil. Daikon radish is winter terminated, but cereal rye is winter hardy, which will provide soil cover in the spring that can further stabilize $\mathrm{N}$ mineralized from the winter terminated daikon radish along with any residual $\mathrm{N}$ or $\mathrm{N}$ from fertilizer applied in the fall. 


\section{Cultural Practices}

All field practices and applications are designed to follow common agricultural practices in the Midwest and were influenced by the farmer participating in this study (see Chapter 3, Figure 3). A corn-soybean cropping system rotation was used for this study. Both the corn and soybeans were planted in $76.2 \mathrm{~cm}$ rows with the target planting rate for corn at 79,100 seeds per hectare and for soybeans at 344,400 seeds per hectare. The planting and harvest dates of the cash crops varied year-to-year dependent on the weather. All treatments, except the Zero Control, received a total of $224 \mathrm{~kg} \mathrm{~N} \mathrm{ha}^{-1}$ for the corn cash crop. The $\mathrm{N}$ source used in the fall and spring was anhydrous ammonia, which is commonly used by farmers in the region. The $\mathrm{N}$ management strategy was to apply a total rate of approximately $224 \mathrm{~kg} \mathrm{~N} \mathrm{ha}^{-1}$ across various timings of $\mathrm{N}$ application. The treatments that received the dominated portion of the applied fertilizer $\mathrm{N}$ in the fall received $80 \%$ of the total $\mathrm{N}$ in the fall and $20 \%$ in the spring and the dominantly spring applied treatments received $30 \%$ of the total $\mathrm{N}$ rate in the fall and $70 \%$ in the spring. While the spring $\mathrm{N}$ management system did not receive fall anhydrous ammonium, the tool bar was ran through the plots when the anhydrous ammonium for the fall systems was applied to create the tillage strips for the planting of the corn in the following spring. All fall anhydrous ammonium was applied with a nitrogen inhibitor (N-Serve). Spring application of $\mathrm{N}$ was applied as a sidedress using anhydrous ammonium without $\mathrm{N}$-serve in the beginning of June.

Cover crops (cereal rye and daikon radish mixture) were seeded into the standing cash crop at a rate of $84.1 \mathrm{~kg} \mathrm{ha}^{-1}$ using a high-rise planter in early to mid-September (see Chapter 3, Figure 2). Throughout the duration of the study, daikon radish plants winter terminated 2-4 months after planting from subfreezing temperatures and vegetative desiccation. In mid-April, chemical termination of the cereal rye was accomplished using a non-selective herbicide 
(Glyphosate and 2, 4-Dichlorophenoxyacetic acid) at least two weeks before the anticipated planting of the cash crop.

\section{Plant Sampling}

Cover crops were sampled for above ground biomass and $\mathrm{N}$ uptake in the fall prior to the winter termination of the daikon radish and in the spring before chemical termination of the cereal rye. Within each cover crop plot, four $0.6858 \mathrm{~m}^{2}$ quadrant samples were randomly selected and the above ground biomass was harvested to make a composite sample. This sampling method was modified from the method developed be Dean and Weil (2009). The cover crop samples were over dried at $60^{\circ} \mathrm{C}$, weighed to determine the dry weight, and ground to pass through a 1mm sieve. Total percent N was determined with a Flash $2000 \mathrm{NC}$ using a dry combustion method. Nitrogen uptake was calculated by multiplying $\% \mathrm{~N}$ by the dried biomass weight of the plot.

\section{Grain Yield Sampling}

Cash crop grain yield and moisture data was collected during the harvest of each plot. Grain yield were determined with a weigh wagon following the harvest of a measured area. A subsample of each plot was collected to determine the moisture of the grain. The weight of the grain is standardized to $15 \%$ moisture for the corn, and $13 \%$ for soybeans. These measurements were used to determine the cash crop grain yield on a per hectare basis. 


\section{Water Sampling}

In order to determine the nutrients (nitrogen and phosphorus) leaving the field through the subsurface drainage system, an automated tile water monitoring and sampling system was employed up. The system included an ISCO 6712 automated water sampling unit, an ISCO 2105 communication module, and an ISCO 2150 data logger module, all of which were powered by a marine grade 12 volt battery maintained through the use of a solar panel and power inverter (Figure 1). These instruments were selected due to the previous experience with equipment and knowledge of system. Each treatment had a controlled drainage structure in which a water velocity sensor and the sampling line from the automated water sampler were placed. 


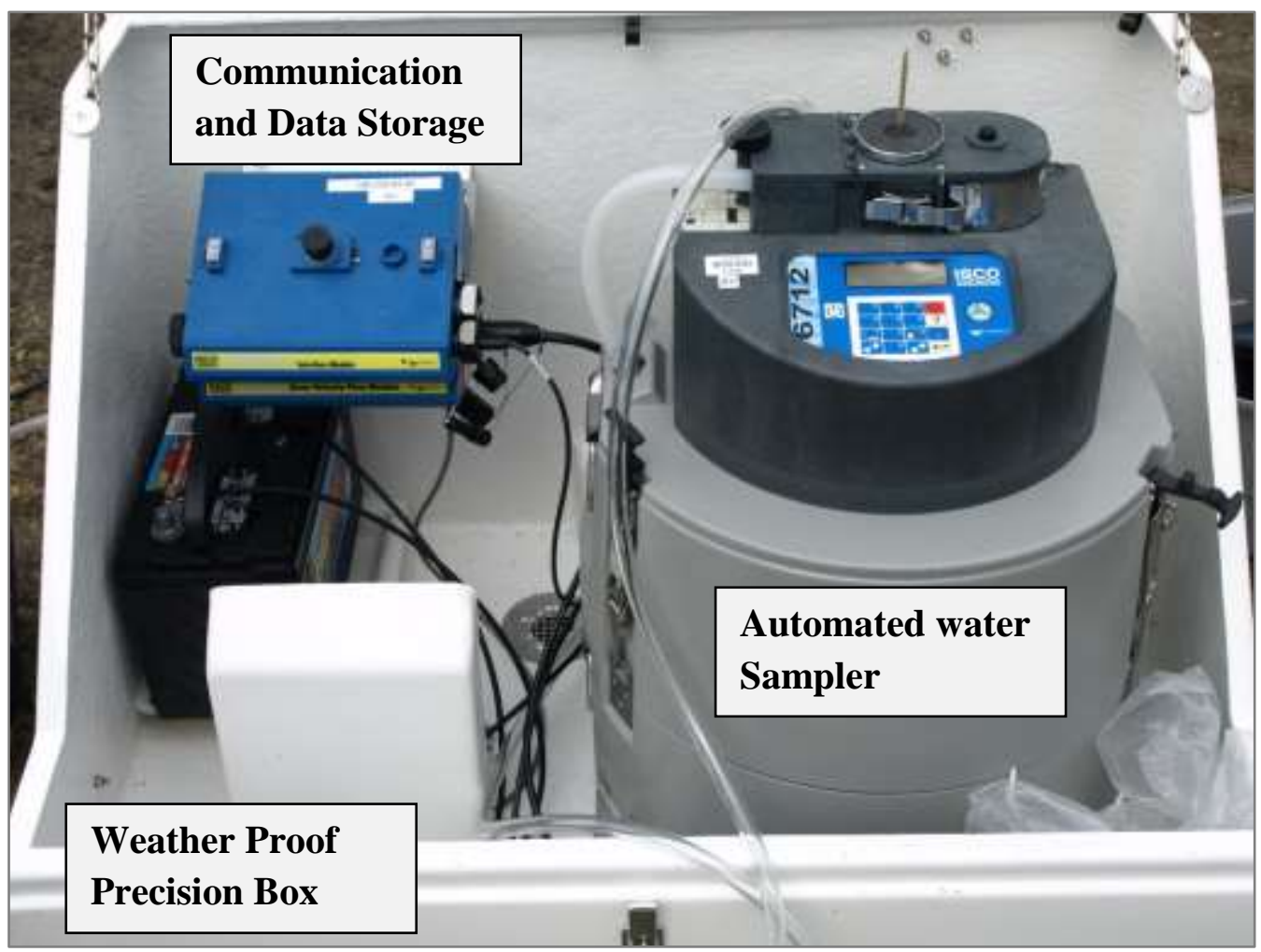

Figure 1. Water monitoring and sample collection system. This system is powered by a deep marine cycle battery and maintained with a solar panel and power converter.

The automated water samplers were programmed to start collecting water samples once the level of the water in the tile reached an individually determined baseline level for each plot. Once the sampling trigger was reached, the sampler first purged the tubing with water from the tile to remove any residual water from the previous sample. The automated sampler then collected a $200 \mathrm{ml}$ sample every hour and formed a three-hour composite $(600 \mathrm{ml})$ sample in each of the twenty-four bottles. The sampling program could run for seventy-two hours before the bottles in the sampler would need to be replaced. When the sampler program was complete, each plots hydrograph was analyzed and samples were selected to represent the base flow, rising 
limb, peak flow, falling limb, and inflection point of the hydrograph using the Flowlink software (Figure 2). After samples were selected for water quality analysis, all bottles were replaced in the field and the programs was restarted. Each of the samples that were selected to be analyzed were filtered with 0.45 micron filter paper to remove any suspended particulates and analyzed for nitrate, ammonium, and phosphorus concentrations using a LATCHAT flow injection analysis auto sampler.

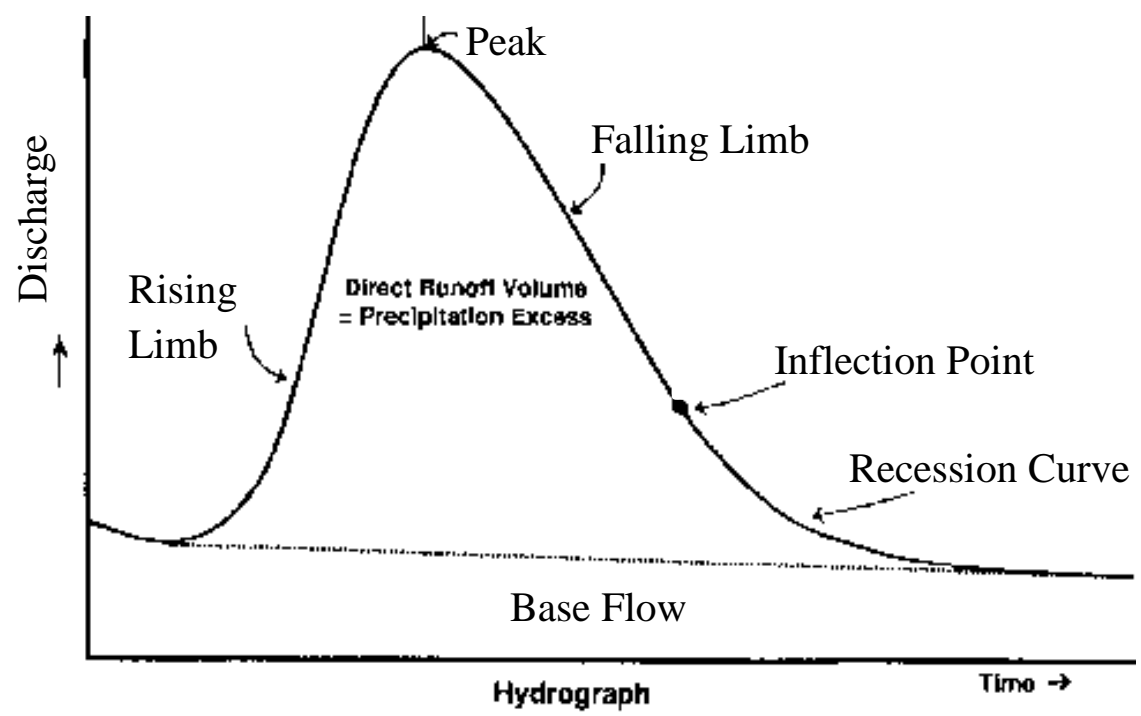

Figure 2. Example of a typical hydrograph with hydrograph terminology

\section{Statistical Analysis}

All data was analyzed using a randomized block analysis of variance test (ANOVA) at an alpha level of 0.05 procedure in SAS 9.3. If the analysis of variance (ANOVA) indicated a 
significant difference, then a Ryan's procedure test was used to separate the means. The results was presented as a means and standard errors.

\section{Results}

\section{Environmental Conditions}

To better understand the impact of weather on cover crop growth and $\mathrm{N}$ sequestration, ambient air temperature and total precipitation were recorded over the course of the study (Table B-1). The average ambient air temperature for the 2014 cover crop season (September 2014April 2015) was in general lower than the regional 30-year average with September, November, February, and March $1.1,4.3,6.1$, and $1.9^{\circ} \mathrm{C}$ cooler than the regional 30-year average, respectively. The average ambient air temperature for the 2015 corn season (May-September) was comparable to the regional 30 -year average, averaging only $0.2^{\circ} \mathrm{C}$ cooler. The 2015 cover crop season (September 2015- April 2016) was generally warmer than the regional 30-year average. The monthly ambient air temperatures of September, November, December, February, and March were 1.5, 2.1, 6.0, 1.8, and 3.4 degrees warmer than the regional 30-year average, respectively. During the 2016 soybean season (May-October), the air temperature stayed comparable to the 30 -year regional average.

The total precipitation for the 2014 cover crop growing was considerably lower than the regional 30-year average with $401.1 \mathrm{~mm}$ of precipitation, compared to the regional 30-year average of $571.7 \mathrm{~mm}$. Average precipitation in November 2014 through April of 2015 ranged from $17.7 \mathrm{~mm}$ to $41 \mathrm{~mm}$. below the 30 -year average. The 2015 corn season had considerably higher rainfall when compared to the regional 30-year average with May, June, July, and August resulting in $23.5,78.5,40.9$, and $9.9 \mathrm{~mm}$ more rainfall compared to the 30 -year average, respectively. Record rainfall totals were documented in central Illinois during the June of 2015 
with our research plots totaling $179 \mathrm{~mm}$ while the regional 30 -year average is $100 \mathrm{~mm}$. While there was little difference in total precipitation for the 2015 cover crop season, two of the eight months had considerably more precipitation compared to the regional 30-year average. November and December of 2015 had 22 and 99mm greater precipitation compared to the regional 30-year average, respectively. In the 2016 soybean season, the precipitation total in May and June were similar to the 30-year average; however, July and August totaled 58.7 and $59.2 \mathrm{~mm}$ greater than the 30-year regional average, respectively.

\section{Cover Crop Dry Matter and Nitrogen Uptake}

The 2014 cover crop season preceded a corn cash crop; therefore, the cover crops had the potential to interact with the fertilizer applied in the fall. In the fall of 2014 , the cereal rye and daikon radish in the fall with cover crop treatment (FNCC) and spring with cover crop (SNCC) treatment accumulated a total dry biomass of 332.2 and $265.2 \mathrm{~kg} \mathrm{ha}^{-1}$ and a total $\mathrm{N}$ uptake of 12.3 and $10.9 \mathrm{~kg} \mathrm{ha}^{-1}$, respectively (Table B-4). The daikon radishes in the cover crop mixture were winter killed in late-November to mid-December as a result of colder than average air temperatures in September, October, and November. The remaining cereal rye was sampled before chemical termination in the spring. Compared to the total fall biomass, the remaining spring biomass of the cereal rye in the FNCC and SNCC treatments resulted in a significantly greater biomass and $\mathrm{N}$ uptake with $1,179.6$ and $1033.7 \mathrm{~kg} \mathrm{ha}^{-1}$ of biomass and a total $\mathrm{N}$ uptake of 61.5 and $45.6 \mathrm{~kg} \mathrm{~N} \mathrm{ha}^{-1}$ of total $\mathrm{N}$ uptake, respectively (Table B-2; Table B-3; Table B-4).

The 2015 cover crop season preceded a soybean cash crop, so no fertilizer was applied. In contrast to the previous cover crop season, the cover crops only had the potential to interact with naturally mineralized $\mathrm{N}$ and residual $\mathrm{N}$ from the corn season. In the fall of 2015 , the cereal rye and daikon radish in the FNCC and SNCC treatments accumulated a total biomass of 1,375.4 
and $1459.1 \mathrm{~kg} \mathrm{ha}^{-1}$ and absorbed 54.9 and $63.9 \mathrm{~kg} \mathrm{~N}^{\text {ha-1}}$, respectively. Above average air temps in September, October, November, and December resulted in a later winter termination of the daikon radish in late-December to late January, which contributed to significantly greater biomass production and $\mathrm{N}$ uptake compared to the 2014 fall biomass sampling (Table B-2 and Table B-3). After the senescence of daikon radish in the winter, the remaining cereal rye was sampled before chemical termination in the spring. The FNCC and SNCC treatments resulted in a biomass of $1,072.7$ and $1,373.8 \mathrm{~kg} \mathrm{ha}^{-1}$ and a total $\mathrm{N}$ uptake of 29.0 and $33.7 \mathrm{~kg} \mathrm{~N} \mathrm{ha}^{-1}$, respectively. The $\mathrm{N}$ uptake was significantly less in the 2015 spring sampling compared to the 2014 spring sampling for both treatments (Table B-2 and Table B-3).

\section{Cash Crop Yields}

For the 2015 corn crop, yields were determined from 24 rows, measured using a weigh wagon, and adjusted to $15.5 \%$ moisture content. No significant difference was observed between the FN and FNCC treatments which yielded 12.83 and $12.82 \mathrm{Mg} \mathrm{ha}^{-1}$, respectively. A significant decrease was observed with the addition of cover crops within the spring nitrogen management system, with the SN and SNCC yielding 13.27 and $12.35 \mathrm{Mg} \mathrm{ha}^{-1}$, respectively. No significant differences were observed between the SN and FN treatments or the FNCC and SNCC treatments. A significant difference was observed between all of the treatments that received $\mathrm{N}$ relative to the Zero Control, which yielded 4.62 $\mathrm{Mg} \mathrm{ha}^{-1}$. In the 2016 soybean cash crop, there were no significant difference in yield for any of the treatments (Table B-5; Table B-6).

\section{Total Discharge}

To fully understand the impact of cover crops and $\mathrm{N}$ fertilizer application timing on nutrient loads and flow-weighted concentrations, the data was summarized by year, season, and treatment. The term "year" refers to the time frame from one cover crop planting to the next 
(September - September). The information was also divided into 4 seasons: 2014 cover crop season, 2015 corn seasons 2015 cover crop season, and 2016 soybeans season. The cover crop seasons will represent all of the rainfall events that occurred from cover crop planting to the terminations of the cover crop in a given year. The 2015 corn season will represent all of the rainfall events that occurred from the termination of the cover crop (mid-April) to the planting of the following cover crops (early September). The 2016 soybean season will represent all of the rainfall events that occurred from the termination of the cover crop to the planting of the following cover crop (early to mid-September).

Tile water was analyzed for total flow, nitrate load, flow-weighted nitrate, ammonium $\left(\mathrm{NH}_{4}\right)$ load, flow-weighted $\mathrm{NH}_{4}$, dissolved reactive phosphorus (DRP) load, and flow-weighted DRP. The water data was run as a MANOVA and significant differences were detected within year, season, and treatment, but the interactions between (year*treatment) and (season*treatment) were not found significant (Table B-7).

To determine differences in flow for each treatment, the cumulative drainage for each season was calculated by summing the discharge volume from each plot within a season and dividing by the plot area. No significant differences were observed between treatments, however significant differences were observed between years and seasons (Table B-14; Figure B-1). The data indicated that there was significantly greater cumulative subsurface drainage in the 2016 soybean year compared to the 2015 corn year (Figure B-2). The results showed that the 2015 CC season lost significantly more water compared to all other seasons. While there was no significant difference between the 2015 corn and 2016 soybean seasons, both had greater cumulative subsurface drainage compared to the 2014 CC season (Figure B-3). 
While not significant, a trend between treatments in both the $14 \mathrm{CC}$ and $15 \mathrm{CC}$ seasons was observed. The inclusion of cover crops resulted in a substantial reduction in the total amount of water leaving the field through subsurface drainage (Figure B-3). Within the spring dominated $\mathrm{N}$ management system, the inclusion of cover crops resulted in a $40-42 \%$ reduction in total flow. Within the fall dominated $\mathrm{N}$ management system, the inclusion of cover crops resulted in a 32-34\% reduction in total water lost through subsurface drainage. In the 2014 cover crop season, the Zero Control treatment had the greatest cumulative drainage compared to all other treatments. In most seasons, the Zero Control total flow acted similar to or had greater flow than the FN and SN treatments.

\section{Tile Drainage Nitrate Load}

Due to variability across the field, no significant differences were detected within treatment or year, but significant differences were observed between different seasons (Table B8). The results indicated that the nitrate load was significantly greater in the $2015 \mathrm{CC}$ season and the 15 corn seasons when compared to the 2014 CC and 2016 soybean season (Figure B-6).

While not significant due to the variability across the field, a trend was observed between treatments in both the corn year and soybean year. In the corn year, the inclusion of cover crops resulted in a 27 and $13 \%$ reduction in nitrate load in the fall and spring systems, respectively. In the soybean year, the addition of cover crops resulted in a 56 and $64 \%$ reduction in nitrate load in the fall and spring systems, respectively (Figure B-5). Similarly, when the treatments were compared by season, a trend was observed in the 2014 CC season and the 2015 CC season. The inclusion of cover crops resulted in a 59-67\% reduction of nitrate load via subsurface drainage in a spring system and a 51-59\% reduction in a fall system during the cover crop seasons (Figure B6). In the $2015 \mathrm{CC}$ season, a $47 \%$ increase in nitrate load was also observed in the $\mathrm{SN}$ treatment 
compared to the FN. In the 2015 corn season, a $20 \%$ reduction in nitrate load was observed when the majority of the $\mathrm{N}$ fertilizer applied is moved from the fall to the spring. In the 2015 corn season, a $19 \%$ reduction of nitrate load was also observed with the inclusion of cover crops in the fall $\mathrm{N}$ application treatments. In the 2016 soybean season, a $45 \%$ and $52 \%$ reduction was observed with the inclusion of cover crops in the fall and spring systems, respectively. Contradictory to the 2015 corn season, there was a $71 \%$ increase in $\mathrm{NO}_{3}-\mathrm{N}$ load in the $\mathrm{SN}$ treatment when compared to the FN.

\section{Flow-weighted Nitrate Concentration}

Significant differences in the flow-weighted nitrate concentration for the subsurface tile drainage were observed for year, season, and treatment, however no significant differences were observed in the interactions between (treatment*season) or (treatment*year) (Table B-7; Table B-9). The results indicated that the 2015 corn year $(8.5 \mathrm{mg} \mathrm{NO}-\mathrm{N} / \mathrm{L})$ had a significantly higher flow-weighted nitrate concentration compared to the 2016 soybean year $\left(4.80 \mathrm{mg} \mathrm{NO}-\mathrm{N} \mathrm{L}^{-1}\right)$ (Figure B-8); however, the 2015 CC season received 250mm more precipitation compared to the 2014 CC season and had significantly greater flow. The differences detected within seasons showed significantly higher flow-weighted nitrate concentrations in the 2015 corn season compared to the $2014 \mathrm{CC}$ and 2016 soybean seasons. Over the course of the study, it was determined that the FN treatment $(7.3 \mathrm{mg} / \mathrm{L})$ had a significantly higher flow-weighted nitrate concentration compared to the Zero Control $(5.76 \mathrm{mg} / \mathrm{L})$ and the SNCC treatment $(5.40 \mathrm{mg} / \mathrm{L})$

(Table B-9; Figure B-7). The flow-weighted concentrations for the treatments over the course of the study resulted as follows: $\mathrm{FN}>\mathrm{SN}>\mathrm{FNCC}>$ Zero Control $>\mathrm{SNCC}$. 
While the interactions between treatment*season and treatment*year were not significant (Table B-7), trends could be observed. The addition of cover crops in the fall system reduced the flow-weighted nitrate concentration by $3 \%$ in the corn year and 32\% in the soybean year. The inclusion of cover crops in the spring system reduction the flow-weighted nitrate concentration by $8 \%$ in the corn year and 39\% in the soybean year (Figure B-8). In the 2015 CC season, a 26 and 33\% reduction in flow-weighted nitrate concentration was observed with the inclusion of cover crops in the fall and spring $\mathrm{N}$ management systems respectively. In the 2016 soybean season, a 40 and $46 \%$ reduction in flow-weighted nitrate concentration was observed with the inclusion of cover crops in the fall and spring N managements systems, respectively (Figure B9).

\section{Tile Drainage Ammonium Load}

No significant differences were observed for $\mathrm{NH}_{4}$ load within year, season, or treatment (Table B-10; Figure B-10); however, biological trends was observed with the inclusion of cover crops by year and in the cover crops seasons. The addition of cover crops in the fall system reduced the $\mathrm{NH}_{4}$ load by $21 \%$ in the corn year and $39 \%$ in the soybean year. The inclusion of cover crops in the spring system reduction the $\mathrm{NH}_{4}$ load by $32 \%$ in the corn year and $35 \%$ in the soybean year (Figure B-11). While not significant, during the cover crop seasons a 47-68\% reduction in $\mathrm{NH}_{4}$ load was observed with the inclusion of cover crops in the spring system and a 44-78\% reduction in the fall system (Figure B-12).

\section{Flow-weighted Ammonium Concentration}

Significant differences were observed in flow-weighted ammonium concentrations within year and season; however no significant differences were observed between treatments (Figure B-13) over the course of the study (Table B-11). The results indicated that the flow-weighted 
$\mathrm{NH}_{4}$ concentration was significantly higher in the corn year $(0.022 \mathrm{mg} / \mathrm{L})$ compared to the soybean year $(0.012 \mathrm{mg} / \mathrm{L})$ (Figure B-14). Trends observed within the different seasons followed the trends that were observed between the two years. The flow-weighted $\mathrm{NH}_{4}$ concentration in the $2014 \mathrm{CC}$ and the 2015 corn seasons were significantly greater when compared to the 2015 CC and 2016 soybean season (Figure B-15). In addition, the 2015 CC season had significantly higher flow-weighted $\mathrm{NH}_{4}$ concentrations compared to the 2016 soybean season.

While the interaction for season*treatment was insignificant (Table B-7), a trend was observed between the $\mathrm{SN}$ and SNCC treatments. While all $\mathrm{NH}_{4}$ concentrations measured within the subsurface tile drainage were considerably low, an average increase of $36 \%$ in flow-weighted $\mathrm{NH}_{4}$ concentration was observed with the inclusion of cover crops in the fall dominated $\mathrm{N}$ application system.

\section{Tile Drainage DRP Load}

No significant differences were observed in dissolved reactive phosphorus (DRP) load between treatments (Figure B-16) or year; however, significant differences were detected between seasons (Table B-12). The results revealed significantly larger DRP load in the 2015 corn and the 2015 CC seasons compared to the 2014 CC season, which was also significantly more than the 2016 soybean season. While no trends were observed in DRP load in the corn year, a 15 and $32 \%$ reduction was observed in the soybean year with the inclusion of cover crops in the spring and fall systems, respectively (Figure B-17).

While the differences were not significant due to variability, in the $2014 \mathrm{CC}$ season, a 90\% reduction in DRP load was observed with the inclusion of cover crops in the spring system and a $69 \%$ reduction in the fall system (Figure B-18). Similar trends were observed in the 2015 CC season with a $15 \%$ and $37 \%$ reduction in DRP load with the addition of cover crops in the 
spring and fall systems, respectively. The DRP load in the SN treatment was $154 \%$ greater compared to the FN in the 2014 CC season. Contrary to the 2014 CC season, in the 2015 CC season a $29 \%$ decrease in DRP load was observed in the SN treatment when compared to the FN treatment.

In the 2015 corn season, a 29\% decrease in DRP load was observed with the inclusion of cover crops in the fall system and a $48 \%$ reduction in DRP load when the SN treatment is compared to the FN treatment. Unlike the fall system, in the 2015 corn season the inclusion of cover crops in the spring system resulted in a 102\% increase in DRP load. In the 2016 soybean season, little to no impact on DRP load was observed with the inclusion of CC in the fall system; however, a 15\% reduction was observed in the spring system. In addition, an 18\% increase in DRP load was observed when the FN treatment was compared to the SN.

\section{Flow-weighted DRP Concentration}

No significant differences were observed in the flow-weighted DRP concentrations of the subsurface tile drainage within year, season, or treatment (Table B-13, Figure B-19). Similar to what was observed in the DRP load, a 107\% increase in flow-weighted DRP concentration was observed when the SN treatment was compared to the $\mathrm{FN}$ and a 17\% decrease was observed with the inclusion of CC in the spring system. The inclusion of cover crops in the spring system resulted in a 2 and $12 \%$ increase in flow-weighted DRP concentration in the corn and soybean years, respectively. Similarly, the addition of cover crops in the fall systems resulted in a 23 and $16 \%$ increase in flow-weighted DRP concentration in the corn and soybean years, respectively (Figure B-20). During the 2015 corn season, small differences were observed in the fall system with the inclusion of cover crop and when the FN treatment was compared to the SN (Figure B21); however, a 44\% increase in flow-weighted DRP concentration was observed with the 
addition of CC in the spring system. While no major differences were observed in the 2015 CC season, in the 2016 soybean season a 19\% increase in flow-weighted DRP concentration was observed in the fall system with the inclusion of CC.

\section{Discussion}

The $2014 \mathrm{CC}$ season ambient air temperature was generally lower than the 30 year average with November averaging $4.3^{\circ} \mathrm{C}$ below and the precipitation totals were $30 \%$ less relative to the 30 year average. The $2015 \mathrm{CC}$ season experienced considerably warmer average ambient air temperatures relative to the 30 year average, with December averaging $5.8^{\circ} \mathrm{C}$ above and above average precipitation in November and December relative to the 30 year average. The colder air temperature in the $2014 \mathrm{CC}$ season resulted in poor growth of the daikon rakish in the fall and a much earlier termination date when compared to the 2015 CC season, which was considerably warmer. The combination of below average air temperature and below average precipitation in the $2014 \mathrm{CC}$ season resulted in a significant reduction of $75 \%$ less biomass production and N uptake at the fall sampling relative to the $2015 \mathrm{CC}$ season. In 2014, although unfavorable weather conditions during the $\mathrm{CC}$ season resulted in poor biomass production and $\mathrm{N}$ uptake from the radish and cereal rye mixture in the fall, there was considerable biomass and $\mathrm{N}$ uptake from the cereal rye in the spring. The drastic difference in biomass and $\mathrm{N}$ uptake can be attributed to the winter hardiness of the cereal rye, the spring warm up, and a possible relay of $\mathrm{N}$ from the decomposing radish to the vigorously growing cereal rye. These results demonstrate the security of planting a cover crop mixture that provides aggressive fall and spring growth. In the $2015 \mathrm{CC}$ season, above average ambient air temperature and precipitation in the fall and early winter resulted in greater growth of the daikon radish due to a longer growing period from planting to the killing frost. In addition, while the biomass of the cereal rye in the spring of the 
2015 CC season was comparable to the values in the spring of the 2014 CC season, we observed considerably less $\mathrm{N}$ uptake from cereal rye in the $2015 \mathrm{CC}$ season. This reduction in $\mathrm{N}$ uptake with no reduction of biomass production could be a result of drastically lower soil TIN in the spring of 2016 relative to the spring of 2015. Several factors contributed to lower soil TIN values in the spring of 2016. The first factor is the 2015 CC season preceded a soybean cash crop so no N fertilizer was applied. Secondly, the warm winter of 2015 with excessive amounts of rainfall in November and December provided ideal condition for $\mathrm{N}$ losses from the soil through leaching and denitrification. As a result, in a cover crop season with weather condition that are ideal for losses of any residual $\mathrm{NO}_{3}-\mathrm{N}$ and with no addition of fertilizers to resupply the pool of inorganic $\mathrm{N}$, we observed a substantial reduction in the $\mathrm{N}$ uptake of the cover crop.

The 2014 cover crop season preceded a corn cash crop, so cover crop biomass and $\mathrm{N}$ uptake were evaluated between the two different $\mathrm{N}$ fertilizer application systems used in this study (see treatments mentioned previously). In the 2014 CC season, the FNCC treatment yielded a greater biomass and $\mathrm{N}$ uptake at both the fall and spring sampling dates relative to the SNCC treatment. This is likely due to the fact that the cover crops in the FNCC treatment not only interacted with naturally mineralized $\mathrm{N}$ and residual $\mathrm{N}$, but the cereal rye also had the opportunity to interact with the fall applied anhydrous ammonia. In comparison, the cover crop in the SNCC treatment could only interact with the naturally mineralized $\mathrm{N}$ and residual $\mathrm{N}$. The 2015 CC season preceded a soybean cash crop so no fertilizer was applied. At both the fall and spring cover crop sampling dates, the cover crops in the SNCC treatment yielded a higher biomass production and $\mathrm{N}$ uptake compared to the FNCC treatment. This is likely a consequence of a larger portion of $\mathrm{N}$ fertilizer in this treatment applied as sidedress mid-summer, potentially resulting in a larger residual pool of nitrogen. According to the observed differences 
in biomass production and $\mathrm{N}$ uptake by both cover crops in the mixture in response to climatic differences, we noted that the fall growth of radish is dominant during warmer falls and cereal rye growth excels in cold falls and warm springs. This observation demonstrates the synergy and added security of an impactful cover crop stand including multiple species.

In the scientific literature, the integration of cover crops has dominantly been in spring $\mathrm{N}$ application systems, where the purpose of the cover crops were to interact with residual $\mathrm{N}$ from the previous cash crop season or naturally mineralized N (McCracken et al., 1994). According to the scientific literature, cover crop $\mathrm{N}$ uptake in a spring $\mathrm{N}$ fertilizer application system ranged from 37-83 $\mathrm{kg} \mathrm{N} \mathrm{ha}^{-1}$ for cereal rye in Maryland (Dean and Weil, 2009) and 9-76 $\mathrm{kg} \mathrm{N} \mathrm{ha}^{-1}$ for cereal rye in a four year study in Iowa (Kasper et al., 2007). In the FNCC treatment of our study, $70 \%$ of the $\mathrm{N}$ was fall applied so there is a great possibility that cover crops interacted with a portion of the $\mathrm{N}$ fertilizer applied in the fall. Despite dynamic weather conditions between the two cover crop seasons, the cover crops in both the SNCC and FNCC treatments demonstrated the ability to sequester an average of 39 and $45 \mathrm{~kg} \mathrm{~N} \mathrm{ha}^{-1}$, respectively, at the time of chemical termination in the spring. This observation demonstrates that over the two years of this study, the cover crops sequestered on average of $30 \%$ of the total amount of $\mathrm{N}$ fertilizer applied in the fall treatment and $100 \%$ of fall $\mathrm{N}$ as DAP in our spring system. This is comparable to Kasper et al. (2007) which showed that when cereal rye is used in a corn-soybean rotation with all of the $\mathrm{N}$ fertilizer applied as sidedress with urea, the cereal rye on average sequestered $47.5 \mathrm{~kg} \mathrm{~N} \mathrm{ha}^{-1}$, averaging an uptake of about $20 \%$ of the total $\mathrm{N}$ fertilizer applied over the four years of the study.

Over the course of this two year study, we were able to observe the impact of $\mathrm{N}$ application timing and cover crops on the total discharge, nutrient load, and flow-weighted 
nutrient concentration of subsurface tile drainage. While none of the treatments within a given crop phase were significantly different, visible trends between treatments for different variables could be detected. When the total subsurface tile drainage discharge was compared between treatments in the corn year, there was no impact of cover crop in the spring system; however, in the fall system an $18 \%$ reduction was measured with the inclusion of cover crops. In comparison, in the soybean year a $32 \%$ reduction in subsurface discharge was measured with the inclusion of cover crop in the spring $\mathrm{N}$ application system along with a $26 \%$ reduction in the fall $\mathrm{N}$ application system. A four year study done by Kasper et al. (2007), recorded an average of a $9 \%$ reduction in total subsurface drainage with the inclusion of a cereal rye cover crop into a corn-soybean rotation; however, they also found the differences to be insignificant due to plot-toplot variability in drainage. Strock et al. (2004), reported a significant $11 \%$ reduction in subsurface tile drainage discharge in a corn-soybean cropping rotation with a cereal rye cover crop following corn compared to a no rye cover crop treatment. This reduction is likely a result of increased plant transpiration during the cover crop season when compared to the treatments without cover crops. Kasper et al. (2007), also contributes the reduction in tile drainage discharge to cover crops increasing plant transpiration compared to the plots without cover crops. In both years, the Zero Control treatment yielded the highest tile drainage discharge relative to the other treatments. This could potentially be attributed to nitrogen deficient plants in the Zero Control not applying a strong demand on soil water, thus more water was allowed to drain from the soil profile.

To further understand the impact of the cover crops impact, we divided our data into 4 seasons: 2014 cover crop season, 2015 corn season, 2015 cover crop season, and 2016 soybean season. By separating the data out into seasons we can determine how the cover crops are 
impacting the subsurface tile drainage discharge, while the cover crops are actively growing relative to when the cash crop is growing. While the interaction between treatment and season was insignificant, there was a reduction in tile drainage discharge when the cover crop mixture was actively growing in both 2014 and 2015. When both cover crop seasons were compared, we found a $40-42 \%$ and a $32-34 \%$ reduction in total discharge for cover crop fall and spring $\mathrm{N}$ application systems with cover crops, respectfully. This reduction in flow during the cover crop season could also be a contributing factor in the reduction observed when analyzing $\mathrm{N}$ loading among treatments. The presence of cover crops increases the cropping intensity and transpiration, which decrease the antecedent soil moisture and increases the soil matric potential resulting in reduced leaching potential of water. In the 2015 corn season, we did not observe an impact of cover crops on the total amount of subsurface drainage leaving the field through the tile. The only noticeable trend was that the Zero Control treatment resulted in over $100 \mathrm{~mm}$ more tile drainage discharge compared to the other treatments. Similarly, in the 2016 soybean season, there was no difference in tile drainage discharge when the treatments with cover crops were compared to the treatments without. Again, the only treatment that differed was the Zero Control treatment which yielded $161 \mathrm{~mm}$ greater tile drainage discharge relative to the other treatments. This could be related to poor plant health in the Zero Control treatments as a result of nitrogen deficiency which would result in less plant transpiration relative to the treatments that were not suffering from $\mathrm{N}$ deficiencies. By dividing the data into cover crop and cash crop seasons, we are able to confirm that the reductions in total subsurface discharge were a result of reductions in discharge from the cover crop plots during the cover crop season and that cover crop plots had no impact on tile drainage discharge during the cash crop seasons. These 
observations also agree with our data generated from the examination of $\mathrm{NO}_{3}-\mathrm{N}$ load among treatments over the two year examination period.

No significant difference in the $\mathrm{NO}_{3}-\mathrm{N}$ load was observed in the corn year relative to the soybean year. While the interaction between year and treatment was insignificant, there were visible impacts of $\mathrm{N}$ application timing and cover crops on the $\mathrm{NO}_{3}-\mathrm{N}$ load of the tile drainage. When comparing the fall and spring $\mathrm{N}$ application systems without cover crops in the corn year, we observed an $18 \%$ reduction in $\mathrm{NO}_{3}-\mathrm{N}$ load in the $\mathrm{SN}$ treatment compared to the $\mathrm{FN}$ treatment. In the same time period (corn year) a reduction in $\mathrm{NO}_{3}-\mathrm{N}$ load was also observed in the spring and fall systems with the addition of cover crops. A $13 \%$ reduction in $\mathrm{NO}_{3}-\mathrm{N}$ load was observed with the addition of cover crops in the spring system along with a $27 \%$ reduction in $\mathrm{NO}_{3}-\mathrm{N}_{\text {load }}$ in the fall system. Contrary to the corn year, in the soybean year a $52 \%$ increase in $\mathrm{NO}_{3}-\mathrm{N}$ loads was observed in the $\mathrm{SN}$ treatment relative to the $\mathrm{FN}$. This observation is comparable to a study conducted by Randall et al. (2003) in which moving fall $\mathrm{N}$ fertilizer application to the spring can increase $\mathrm{NO}_{3}-\mathrm{N}$ losses in the soybean phase of a corn-soybean rotation by as much as $80 \%$. The inclusion of cover crops in the soybean year resulted in a $64 \%$ and $56 \%$ reduction in $\mathrm{NO}_{3}-\mathrm{N}_{\text {load }}$ in the spring and fall systems, respectively. Although the cover crops were terminated before the 2016 soybean season, we attribute the reduction in $\mathrm{NO}_{3}-\mathrm{N}$ loading via tile drainage to the $\mathrm{N}$ scavenging of the winter cover crop. Nitrogen absorbed by cover crops in the winter is assimilated into the organic structure of the plant and is slowly released over time, which prevents $\mathrm{N}$ leaching. These reduction in $\mathrm{NO}_{3}-\mathrm{N}$ loads are comparable to a study by Kasper et al (2007) in Iowa which reported an average of $61 \%$ reductions in $\mathrm{NO}_{3}-\mathrm{N}$ load to tile drainage water in a sidedress $\mathrm{N}$ application system with the inclusion of a cereal rye cover crop in a cornsoybean rotation. According to Kladivko et al. (2004), a $60 \%$ reduction in $\mathrm{NO}_{3}-\mathrm{N}$ loads in 
subsurface drainage over the course of a 15 year study in Indiana was recorded through the use of a winter wheat cover crop following the corn phase of a corn-soybean rotation and reduced fertilizer rates of spring applied N. Our results, in conjunction with these other studies, demonstrate the ability of cover crops to reduce the $\mathrm{NO}_{3}-\mathrm{N}$ load of tile drainage from agricultural fields in a dominantly spring applied $\mathrm{N}$ application system; however, in some regions of the Upper Mississippi River basin, 40-75\% of farmers still fall apply N (EPA, 2007; Ribaudo et al., 2012; Smiciklas et al., 2008), so it is important to note that our study also demonstrated the potential for $\mathrm{CC}$ to reduce $\mathrm{NO}_{3}-\mathrm{N}$ loss via tile drainage in fall applied $\mathrm{N}$ application systems. The reductions in $\mathrm{NO}_{3}-\mathrm{N}$ load we recorded in the $\mathrm{SN}$ treatment relative to the $\mathrm{FN}$ treatment are comparable to numerous studies done on the impact of $\mathrm{N}$ application timing on $\mathrm{NO}_{3}-\mathrm{N}$ loading of subsurface tile drainage. A study conducted in Minnesota reports a 9\% reduction in $\mathrm{NO}_{3}-\mathrm{N}$ losses when all $\mathrm{N}$ fertilizer applied in the fall is switched to the spring (Nangia et al., 2008). Randall and Mulla (2001) reported an average of $20 \% \mathrm{NO}_{3}-\mathrm{N}$ load reduction when comparing fall vs. spring nitrogen application over a 4-year period in Minnesota.

When compared to the other treatments, the Zero Control yielded similar $\mathrm{NO}_{3}-\mathrm{N}$ loads in the tile drainage to the FN treatment and $\mathrm{SN}$ treatment. As mentioned previously, poor plant vigor as a result of nitrogen deficiencies could have resulted in less plant transpiration in the Zero Control treatment relative to the other treatments, increasing the amount of water moving through the soil profile and leaving the tile drainage. This could have resulted in greater potential for $\mathrm{NO}_{3}-\mathrm{N}$ leaching than expected.

In the corn year, when the cover crop and corn seasons were compared, reductions in $\mathrm{NO}_{3}-\mathrm{N}$ loss from $\mathrm{N}$ application timing were observed in both seasons. In the cover crop season, an $11 \%$ reduction was measured and in the corn season a $20 \%$ reduction was observed in the $\mathrm{SN}$ 
treatment relative to the FN treatment. Nitrate losses from the Zero Control treatment were comparable to the $\mathrm{NO}_{3}-\mathrm{N}$ losses recorded in the $\mathrm{FN}$ treatment. As expected, the majority of the impact of the cover crops on $\mathrm{NO}_{3}-\mathrm{N}$ load in tile drainage occurred in the cover crop season. In the 2014 CC season, with cold and dry weather conditions, the addition of cover crops resulted in a $59 \%$ reduction in $\mathrm{NO}_{3}-\mathrm{N}$ load in the spring system and a $51 \%$ reduction in the fall system. In comparison, in the corn season, cover crops had a $19 \%$ reduction in $\mathrm{NO}_{3}-\mathrm{N}$ load in the fall system and no effect in the spring system. When the effect of $\mathrm{N}$ application timing was evaluated in the cover crop and soybean seasons within the soybean year, we recorded a $47 \%$ increase in the $\mathrm{NO}_{3}-\mathrm{N}$ load in the cover crop season and a $71 \%$ increase in $\mathrm{NO}_{3}-\mathrm{N}$ load in the soybean season when the SN treatment is compared to the FN treatment. Additionally, impacts of cover crops in both the cover crop and soybean seasons were observed. The 2015 CC season was warm, and wet and as a result we observed a $67 \%$ reduction in $\mathrm{NO}_{3}-\mathrm{N}$ load with the inclusion of cover crop in the spring system and a 59\% reduction with the inclusion of cover crops in the fall system. In the soybean season, we observed a $52 \%$ reduction in $\mathrm{NO}_{3}-\mathrm{N}$ load with the inclusion of cover crop in the spring system and a $45 \%$ reduction with the inclusion of cover crops in the fall system.

Over the course of this two year study, we observed a significant effect of treatment on the flow-weighted $\mathrm{NO}_{3}-\mathrm{N}$ concentration of the tile drainage water (Table 7). We were able to determine that the FN treatment had a significantly higher flow-weighted $\mathrm{NO}_{3}-\mathrm{N}$ concentration relative to the $\mathrm{SN}$ treatment with cover crops and the Zero Control treatment. There was no reduction in flow-weighted $\mathrm{NO}_{3}-\mathrm{N}$ concentration over the course of the study in the $\mathrm{SN}$ treatment relative to the FN treatment. A 16 and $27 \%$ reduction in flow-weighted $\mathrm{NO}_{3}-\mathrm{N}$ 
concentration was observed when cover crops were present in the fall and spring systems, respectively.

The corn year resulted in significantly higher flow-weighted $\mathrm{NO}_{3}-\mathrm{N}$ concentrations compared to the soybean year. It is a common expectation that the flow-weighted $\mathrm{NO}_{3}-\mathrm{N}$ concentration is higher in the corn phase soon after the $\mathrm{N}$ fertilizer application relative to the soybean phase of a corn-soybean rotation (Strock et al., 2004). While there was no significant impact of the interaction of treatment and year on flow-weighted $\mathrm{NO}_{3}-\mathrm{N}$ concentration of the tile drainage water, and trend was observed with the inclusion of cover crops in the corn year. A 3 and $8 \%$ reduction in flow-weighted $\mathrm{NO}_{3}-\mathrm{N}$ concentration was observed as an effect of cover crop inclusion in the fall and spring systems, respectively. The Zero Control treatment in the corn year had a lower flow-weighted nitrate concentration relative to all other treatments. The lower flow-weighted $\mathrm{NO}_{3}-\mathrm{N}$ concentrations in the Zero Control treatment was probably a combination of no $\mathrm{N}$ fertilizers and increased tile drainage discharge as mentioned above. In the soybean year, we documented a larger impact of both $\mathrm{N}$ application timing and cover crops on flowweighted $\mathrm{NO}_{3}-\mathrm{N}$ concentration in tile drainage. When the majority of the $\mathrm{N}$ fertilizer was applied in the spring relative to the fall in the corn year, we observed a $17 \%$ increase in flowweighted $\mathrm{NO}_{3}-\mathrm{N}$ concentration in the soybean year. The addition of cover crops (soybean year) into the fall and springs systems resulted in a 32 and $39 \%$ reduction in flow-weighted $\mathrm{NO}_{3}-\mathrm{N}$ concentration, respectively. While the effects of cover crops were not as pronounced in the corn year, these reductions in the corn and soybean year are comparable to the four year study done by Kasper et al. (2007), in which a rye cover crop reduced flow-weighted $\mathrm{NO}_{3}-\mathrm{N}$ concentrations of the subsurface tile drainage by $59 \%$. 
When the cover crop and corn season are compared within the corn year, there was significantly higher flow-weighted $\mathrm{NO}_{3}-\mathrm{N}$ concentrations in the corn season compared to the cover crop season. While the interaction between treatment and season was insignificant, there were noteworthy trends in the impact of $\mathrm{N}$ application timing and cover crop inclusion on flowweighted $\mathrm{NO}_{3}-\mathrm{N}$ concentration. In the 2014 cover crop season, we observed a $14 \%$ increase in flow-weighted $\mathrm{NO}_{3}-\mathrm{N}$ concentration in the $\mathrm{SN}$ treatment relative to the $\mathrm{FN}$ treatment. In addition while there was no impact of cover crops in the fall system, a $12 \%$ reduction in flowweighted $\mathrm{NO}_{3}-\mathrm{N}$ concentration was recorded with the inclusion of cover crops in the spring system. Similar to the trend observed in the corn year, the Zero Control treatment had the lowest flow-weighted $\mathrm{NO}_{3}-\mathrm{N}$ concentration relative to the other treatments. When the cover crop and cash crop seasons were compared within the soybean year, we see a greater impact of cover crops and $\mathrm{N}$ application timing on the flow-weighted $\mathrm{NO}_{3}-\mathrm{N}$ concentration of the tile drainage. In the cover crop season, we observed an $8 \%$ increase in flow-weighted $\mathrm{NO}_{3}-\mathrm{N}$ concentration in the SN treatment compared to the FN treatment. There was also a $26 \%$ reduction in flowweighted $\mathrm{NO}_{3}-\mathrm{N}$ concertation in the cover crop season when the FNCC treatment was compared to the FN treatment. Similarly the inclusion of cover crops in the spring system resulted in a $33 \%$ reduction in flow-weighted $\mathrm{NO}_{3}-\mathrm{N}$ concentration. An impact of $\mathrm{N}$ application timing was observed in the soybean season with a $33 \%$ increase in flow-weighted $\mathrm{NO}_{3}-\mathrm{N}$ concentration when the SN treatment was compared to the FN. This increase in flow-weighted $\mathrm{NO}_{3}-\mathrm{N}$ concentration in the $\mathrm{SN}$ treatment compared to the FN treatment can be attributed to the fact that the most recent $\mathrm{N}$ fertilizer application was the spring sidedress; in which, the SN treatment received $112 \mathrm{~kg} \mathrm{~N}$ ha $^{-1}$ more sidedress $\mathrm{N}$ than the FN treatment. This could have resulted in a larger residual pool of $\mathrm{N}$ within the $\mathrm{SN}$ treatment, resulting in a greater potential for losses from 
the spring system in the cover crop and the soybean season following the corn cash crop. The addition of cover crops resulted in a 40 and $46 \%$ reduction in flow-weighted $\mathrm{NO}_{3}-\mathrm{N}$ concentration in the fall system and spring system of the soybean season, respectively. As stated previously, this reduction in flow-weighted $\mathrm{NO}_{3}-\mathrm{N}$ concentration can again be attributed to the ability of the cover crops to absorb residual and naturally mineralized $\mathrm{N}$ from the soil; reducing its vulnerability to leaching. However, since the cover crops are not actively growing, we believe that a portion of the $\mathrm{N}$ is still secured in the cover crop residue during the soybean season and is being slowly released back to the soil over time, reducing its leaching potential.

No significant difference in $\mathrm{NH}_{4}$ load was observed between years or the treatment*year interaction; however, non-significant effects of $\mathrm{N}$ application timing and cover crop inclusions were recorded within both the corn and soybean years. In the corn year, we documented a $30 \%$ increase in $\mathrm{NH}_{4}$ load in the $\mathrm{SN}$ treatment relative to the $\mathrm{FN}$ treatment. The Zero Control treatment yielded similar $\mathrm{NH}_{4}$ loads relative to the $\mathrm{SN}$ treatment. Additionally, we recorded a $21 \%$ and $32 \%$ decrease in $\mathrm{NH}_{4}$ load in the tile drainage with the inclusion of cover crops in the spring and fall $\mathrm{N}$ application systems, respectively. Similar trends were observed in the soybean year; moving the majority of the $\mathrm{N}$ fertilizer applied from the fall to the spring resulted in an $8 \%$ increase in $\mathrm{NH}_{4}$ loads in tile drainage. In the soybean year, cover crops reduced $\mathrm{NH}_{4}$ load in the tile drainage by $39 \%$ in the spring system and $35 \%$ in the fall system.

When the cover crop and cash crops seasons of the corn year are compared, the impact of $\mathrm{N}$ application timing and cover crops inclusion on the $\mathrm{NH}_{4}$ load in tile water became clearer. We were able to determine that the cover crops resulted in 68 and $78 \%$ reduction in $\mathrm{NH}_{4}$ load during the cover crop season in the spring and fall systems, respectively; however, the cover crops had no impact on $\mathrm{NH}_{4}$ during the corn season. Nitrogen fertilizer application timing on the other 
hand, had a larger impact (a 73\% increase in the spring treatment without cover crops relative to the fall treatment without cover crops) on $\mathrm{NH}_{4}$ load of the tile drainage during the corn season compared to the cover crop season (a 29\% reduction in the spring treatment without cover crops relative to the fall treatment without cover crops). A similar trend was observed when the cover crop and cash crop seasons were compared in the soybean year. In the cover crop season, while $\mathrm{N}$ application timing had no effect on $\mathrm{NH}_{4}$ load in the tile drainage, the addition of cover crops resulted in a $44 \%$ reduction in the fall system and a $47 \%$ reduction in the spring system. Similar to the corn season, a $74 \%$ increase in $\mathrm{NH}_{4}$ load was observed in the soybean season when the $\mathrm{SN}$ treatment was compared to the FN treatment. This study has demonstrated that while cover crops have little impact on the $\mathrm{NH}_{4}$ load of the tile drainage during the cash crop seasons, cover crops can reduce the $\mathrm{NH}_{4}$ load of the tile drainage 44-78\% during the cover crop season. In addition, this study has also shown a $73-74 \%$ increase in $\mathrm{NH}_{4}$ load when the majority of the fertilizer applied is moved from the fall to the spring. However, the $\mathrm{NH}_{4}$ loads measured in this study were all very low and will likely not be a major contributor to the total dissolved $\mathrm{N}$ within the water. While flow-weighted $\mathrm{NH}_{4}$ concentrations in the corn year were significantly greater relative to the soybean year, no significant differences or general trends were observed as an effect of treatment within years or seasons. Similar to the $\mathrm{NH}_{4}$ loads, the flow-weighted $\mathrm{NH}_{4}$ concentrations in the tile drainage water was extremely low.

No significant differences in DRP loads were observed between the corn year and the soybean year. While not significant, a 15\% reduction in DRP load was observed in the corn year in the SN treatment relative to the FN treatment. Similarly, in the soybean year, a 23\% reduction in DRP load was observed. While non-significant, an impact of cover crops on the DRP load of the tile drainage water was also documented in both the corn and soybean years. In the corn 
year, while no impact on DRP losses was observed in the spring system, the inclusion of cover crops in the fall system reduced the DRP load by $36 \%$. Similarly, in the soybean year, a 15 and $32 \%$ reduction in DRP load was observed when cover crops were added to the spring and fall systems, respectively. When the treatments effect on DRP load is compared between the cover crop and cash crop seasons, we can determine that the reduction in DRP load from the inclusion of cover crops was most substantial during the cover crop seasons. When the 2014 and 2015 cover crop seasons are compared, there was a 15-90\% reduction in DRP load with the addition of cover crops in the spring system and a 37-69\% reduction from cover crop in the fall system. In contrast, no significant impact of cover crops were observed in the either the corn or soybean season. No significant differences or general trends in flow-weighted DRP concentration were observed between treatment within years or seasons.

\section{Conclusion}

This study indicates a cover crop mixture of cereal rye and daikon radish grown in a corn-soybean rotation has the potential to significantly reduce $\mathrm{NO}_{3}-\mathrm{N}$ loading via subsurface drainage systems commonly found in the Midwest Corn Belt. Over the course of this two year study, cover crops reduced $\mathrm{NO}_{3}-\mathrm{N}$ load by $41 \%$ and $44 \%$ in the fall and spring $\mathrm{N}$ fertilizer application systems, respectively. The Illinois Nutrient Loss Reduction Strategy is calling for a $15 \%$ reduction in nitrate load to surface waters by 2025 . This study is evaluating two of the recommended in-field $\mathrm{N}$ loss reduction strategies: the impact of $\mathrm{N}$ application timing in addition to cover crop inclusion in both spring and fall $\mathrm{N}$ fertilizer application systems. This study has shown that cover crops have the potential to significantly decrease the nitrate load of subsurface tile drainage from agricultural fields in both the spring and fall $\mathrm{N}$ management systems. A major contributing factor of the $\mathrm{NO}_{3}-\mathrm{N}$ reduction can be attributed to the ability of the cover crops to 
sequester residual, mineralized, and fall applied $\mathrm{N}$, reducing its vulnerability to leaching and denitrification. We determined that cover crops have the potential to sequester $39-61 \mathrm{~kg} \mathrm{~N} \mathrm{ha}^{-1}$ before the chemical termination of the cereal rye in the spring, even in years of poor fall growth due to adverse weather conditions. Furthermore, the reductions in $\mathrm{NO}_{3}{ }^{-} \mathrm{N}$ load could be attributed to greater transpiration due to cover crops that resulted in less tile drainage discharge. We observed a $32-42 \%$ reduction in total subsurface tile drainage while cover crops were growing.

There is dearth of knowledge on the ability of cover crops to release $\mathrm{N}$ and phosphorus during the cash crop season, following the chemical termination of the cover crop. An analysis of the release of nutrients from the cover crop residue will allow farmers to recognize the short term value of cover crop inclusion. Before there is widespread adoption of winter cover crops in the Midwest Corn Belt, problems such as costs of establishment, logistical conflicts, and potential nutrient credits need to be investigated. In addition, cover crops have been shown to negatively impact corn yields, so a long term study on cover crops impact on corn yield in spring and fall applied $\mathrm{N}$ fertilizer management systems is also needed. 


\section{REFERENCES}

"Cover Crop Survey Report." (2014-2015): n. pag. COVER CROP SURVEY. Conservation Technology Information Center/ Sustainable Agriculture Research and Education, 2015.

Adeli, A., H. Twolde, J. Jenkins, and D. Rowe. 2011. Cover Crop Use for managing broiler litter applied in the fall. Agronomy Journal. 103:200-210.

Baker, J.L., M.B. David, D.W. Lemke, and D.B. Jaynes. 2008. Understanding nutrient fate and transport, including the importance of hydrology in determining field losses, and potential implications for management systems to reduce those losses. p. 1-17. In Upper Mississippi River Subbasin Hypoxia Nutrient Committee (ed.) Final report: Gulf hypoxia and local water quality concerns workshop. Am. Soc. of Agricultural and Biological Engineers, St. Joseph, MI.

Camberato, Jim. 2012. A Historical Perspective on Nitrogen Fertilizer Rate Recommendations for Corn in Indiana (1953-2011). Purdue Extension.

Dabney, S. M., J. A. Delgado, and D. W. Reeves. 2001. Using winter cover crops to improve soil quality and water quality. Communications in Soil Science and Plant Analysis 32:12211250 .

Dean, J., and R. Weil. 2009. Brassica Cover Crops for Nitrogen Retention in the Mid-Atlantic Coastal Plain. Journal of Environmental Quality. 38:520-528.

Dharmakeerthi, R.S., B.D. Kay, and E.G. Beauchamp. 2006. Spatial variability of in-season nitrogen uptake by corn across a variable landscape as affected by management. Agron. J. 98:255-264.

Dinnes, D.L., D.L. Karlen, D.B. Jaynes, T.C. Kaspar, J.L. Hatfield, T.S. Colvin, and C.A.Cambardella. 2002. Nitrogen management strategies to reduce nitrate leaching in tile-drained Midwestern soils. Agron. J. 94:153-171. doi:10.2134/agronj2002.0153

Ditsch, D.C., M.M. Alley, K.R. Kelley, and Y.Z. Lei. 1993. Effectiveness of winter rye for accumulating residual fertilizer $\mathrm{N}$ following corn. J. soil and Water Cons. 48:125-132

Ferguson, Richard. "Ammonia Root Burn on Corn." Cropwatch.unl.edu. Nebraska Extension CropWatch, 5 June 2009. Web. 10 Feb. 2016.

Grant, C.A., G.A. Peterson, and C.A. Campbell. 2002. Nutrient considerations for diversified cropping systems in the northern Great Plains. Agronomy Journal94:186-198.

Greenan, C., T. Moorman, T. Parkin, T. Kaspar, and D. Jaynes. 2009. Denitrification in Wood Chip Bioreactors at Different Water Flows. Journal of Environmental Quality. 38:16641671.

Kaspar, T.C., D.B. Jaynes, T.B. Parkin, and T.B. Moorman. "Rye Cover Crop and Gamagrass Strip Effects on NO Concentration and Load in Tile Drainage." Journal of Environment Quality 36.5 (2007): 1503. Web. 
Kasper, T. C., and M. G. Bakker. "Biomass Production of 12 Winter Cereal Cover Crop Cultivars and Their Effect on Subsequent No-till Corn Yield." Journal of Soil and Water Conservation 70.6 (2015): n. pag. Jswconline.org. Soil and Water Conservation Society, Nov.-Dec. 2015. Web. 2 Feb. 2016

Ketterings, Quirine M., Sheryl N. Swink, Sjoerd W. Duiker, Karl J. Czymmek, Douglas B. Beegle, and William J. Cox. "Integrating Cover Crops for Nitrogen Management in Corn Systems on Northeastern U.S. Dairies." Agronomy Journal 107.4 (2015): n. pag. Sciencesocieties.org. Cornell University, 2015. Web. 9 Feb. 2016.

Kladivko, E.J., J.R. Frankenberger, D.B. Jaynes, D.W. Meek, B.J. Jenkinson, and N.R. Fausey. 2004. Nitrate leaching to subsurface drains as affected by drain spacing and changes in crop production system. J. Environ. Qual. 33:1803-1813.

Kovacic, D., R. Twait, M. Wallace, and J. Bowling. 2006. Use of created wetlands to improve water quality in the Midwest - Lake Bloomington case study. Ecological Engineering. 28:258-270.

McCracken, D., M. Smith, J. Grove, C. MacKown, and R. Blevins. 1994. Nitrate Leaching as Influenced by Cover Cropping and Nitrogen Source. Soil Science Society of America Journal. 58:1476-1483.

Miller, Perry, Will Lanier, and Stu Brandt. "Using Growing Degree Days to Predict Plant Stages." MontGuide Extension Service (2001): n. pag. Msuextension.org. Montant State University Extension Service, July 2001. Web. 13 Jan. 2016.

Moore, E.B., M.H. Wiedenhoeft, T.C. Kaspar, and C.A. Cambardella. 2014. Rye cover crop effects on soil quality in no-till corn silage-soybean cropping systems. Soil Sci. Soc. Am. J. 78:968-976. doi:10.2136/sssaj2013.09.0401

Nangia, V., P. H. Gowda, D. J. Mulla, and G. R. Sands. "Water Quality Modeling of Fertilizer Management Impacts on Nitrate Losses in Tile Drains at the Field Scale." Journal of Environmental Quality (2008): n. pag. Web. 1 Nov. 2016.

Olson, K.R., S.A. Ebelhar, and J.M. Lang. 2010. Cover crop effects on crop yields and soil organic carbon content. Soil Sci. 175:89-98. doi:10.1097 SS.0b013e3181cf7959.

Pantoja, Jose L., Krishna P. Woli, John. E. Sawyer, and Daniel W. Barker. "Corn Nitrogen Fertilization Requirement and Corn-Soybean Productivity with a Rye Cover Crop." Soil Science Society of America (2015): n. pag. Dl.sciencesocieties.org. Web. 22 Feb. 2016.

Paul, E.A., and F.E. Clark. 1996. Soil microbiology and biochemistry. San Diego, CA: Academic Press.

Poffenbarger, Hanna J., and Ray Weil. "NITROGEN DYNAMICS IN COVER CROP - BASED NO - TILL CORN." Thesis. University of Maryland, 2014. Umd.edu/ NITROGEN DYNAMICS IN COVER CROP - BASED NO - TILL CORN. University of Maryland Department of Environmental Science and Technology, 2014. Web. 9 Feb. 2016. 
Randall, G., and J. Vetsch. 2005. Nitrate Losses in Subsurface Drainage from a corn-soybean rotation as affected by Fall and Spring application of Nitrogen and nitraphyrin. Journal of Environmental Quality. 34:590-597.

Randall, G.,J. Vetsch, and J. Huffman. 2003. Corn Production on a Subsurface -Drained Mollisol as affected by time of nitrogen application and nitrapyrin. Agronomy Journal. 95:1213-1219.

Randall, G.W., and D.J. Mulla. 2001. Nitrate nitrogen in surface waters as influenced by climatic conditions and agricultural practices. Journal of Environmental Quality 30:337-344.

Randall, G.W., and J.E. Sawyer. 2008. Chapter 6 - Nitrogen application timing, forms, and additives, p. 73-85 Final report : gulf hypoxia and local water quality concerns workshop. ed. American Society of Agricultural and Biological Engineers, Saint Joseph.

Randall, G.W., J.A. Vetsch, and J.R. Huffman. 2003b. Nitrate losses in subsurface drainage from a cornsoybean rotation as affected by time of nitrogen application and use of nitrapyrin. Journal of Environmental Quality 32:1764-1772

Ranells, N. Nitrogen-15 recovery and release by rye and crimson clover cover crops. Soil Sci. Soc. Am. J. 1997. 61:943-948.

Reeves, D. W., C. W. Woods, and J. T. Touchton. "Timing Nitrogen Applications for Corn in a Winter Legume Conservation-Tillage System." Sciencesocieties.org. USDA-ARS, National Soil Dynamics Lab, Jan. 1993. Web. 18 Feb. 2016.

Reinbott, T.M., S.P. Conley, and D.G. Blevis. 2004. No-tillage corn and grain sorghum response to cover crop and nitrogen fertilization. Agron. J. 96:1158-1163. doi:10.2134/agronj2004.1158

Ribaudo, Marc, Michael Livingston, and James Williamson. Nitrogen Management on U.S. Corn Acres, 2001-10, EB-20. U.S. Dept. of Agriculture, Economic Research Service, November 2012.

SAS 2012 Statistical Analysis Systems. Software Version 9.4, SAS Institute Inc., Cary, NC, USA

Scharf, P.,W. Wiebold, and J. Lory. 2002. Corn Yield Response to nitrogen Fertilizer timing and deficiency level. Agronomy Journal. 94:435-441.

Smiciklas K., A. Moore A.,J. Adams. 2008. Fertilizer Nitrogen Practices and Nitrate Levels in Surface Water within an Illinois Watershed. Journals of Natural Resources and Life Sciences Education. 374:14-19.

Snyder, S. "CORN NITROGEN UPTAKE: SUSTAINED INTO LATER MATURATION." Plant Nutrition Today (2014): n. pag. IPNI. International Plant Nutrition Institute, 2014. Web. 13 Jan. 2016

Strock, J.S., P.M. Porter, and M.P. Russelle. 2004. Cover cropping to reduce nitrate loss through subsurface drainage in the northern U.S. Corn Belt. J. Environ. Qual. 33:1010-1016. 
Sullivan, D. M., and N. D. Andrews. "Estimating Plant -available Nitrogen Release from Cover Crops." (2012): n. pag. Http://ir.library.oregonstate.edu. Oregon State University Extension, Nov. 2012. Web. 16 Feb. 2016.

Thorup-Kristensen, K., J. Magid, and L. S. Jensen. 2003. Catch crops and green manures as biological tools in nitrogen management in temperate zones. Pages 227-302 in Advances in Agronomy, Vol 79. ACADEMIC PRESS INC, San Diego.

United States. USDA. Agricultural Research Service. Using Cover Crops and Cropping Systems for Nitrogen Management. By Seth M. Dabney, Jorge A. Delgado, Jack J. Meisinger, Harry H. Shomberg, Mark A. Leibig, Tom Kasper, Jeffrey Mitchell, and Wayne Reeves. SWCS, n.d. Web. 16 Feb. 2016.

Vetsch, J.A., and G.W. Randall. 2004. Corn production as affected by nitrogen application timing and tillage. Agron. J. 96:502-509

Waskom, Reagan M., and Troy A. Bauder. 2014. "Best Management Practices for Nitrogen Fertilization to Protect Water Quality." Extension.colostate.edu. Colorado State University, Colorado Department of Agriculture and the USDA-NRCS, n.d. Web. 2 Mar. 2016

Weil, R., and A. Kreman. 2006. Thinking across and beyond disciplines to make cover crops pay. Journal of the Science of Food and Agriculture. 87:551-557.

White, Charles M., and Ray R. Weil. "Forage Radish Cover Crops Increase Soil Test Phosphorus Surrounding Radish Taproot Holes." Soil Science Society of America Journal 75.1 (2011): 121. Web.

Wortmann, Charles. "Nitrogen Management for Water Quality Protection in the Midwest." University of Nebraska-Lincoln.edu. Heartland Regional Water Coordination Initiative, 2004. Web. 17 July 2015. 


\section{CHAPTER IV}

\section{CONCLUSION}

This study indicates that in both the spring applied and fall applied $\mathrm{N}$ fertilizer management systems cover crops have the potential to significantly reduce the amount of inorganic $\mathrm{N}$ within the soil profile and its susceptibility to leaching. When the majority of the $\mathrm{N}$ fertilizer is applied in the fall, the inclusion of cover crops reduced the total amount of $\mathrm{NO}_{3}-\mathrm{N}$ that leaches to the environmental region of the soil profile by $33-51 \%$ at the time of chemical termination of the cereal rye in the spring. This reduction in soil $\mathrm{NO}_{3}-\mathrm{N}$ can be attributed to the ability of the cover crops to absorb residual, mineralized, and fall applied N, reducing its vulnerability to leaching and denitrification. We also determined that cover crops have the potential to sequester $39-61 \mathrm{~kg} \mathrm{~N} \mathrm{ha}^{-1}$ by the time of chemical termination of the cereal rye in the spring. The ability of cover crops to absorb $\mathrm{N}$ from the soil profile has also greatly influenced the losses via tile drainage of nutrients within both spring and fall dominated $\mathrm{N}$ fertilizer management systems. The cover crop mixture of cereal rye and daikon radish grown in a cornsoybean rotation has the potential to significantly reduce $\mathrm{NO}_{3}-\mathrm{N}$ loading via subsurface drainage systems commonly found in the Midwest Corn Belt. Over the course of this two-year study, cover crops reduced $\mathrm{NO}_{3}-\mathrm{N}$ load by $41 \%$ and $44 \%$ in the fall and spring $\mathrm{N}$ fertilizer application systems, respectively. The Illinois Nutrient Loss Reduction Strategy mentions a target of 15\% reduction in nitrate load to surface waters by 2025 . This study is evaluating two of the recommended in-field $\mathrm{N}$ loss reduction strategies: the movement of fall applications of $\mathrm{N}$ to the spring and the addition cover crops to the spring $\mathrm{N}$ application systems. We observed a significantly decrease the nitrate loading to the subsurface tile for both the spring and fall $\mathrm{N}$ management systems with the inclusion of cover crops. A contributing factor in the reductions 
of $\mathrm{NO}_{3}{ }^{-} \mathrm{N}$ load could be attributed to less tile drainage discharge when cover crops are present, because of increased plant transpiration from the cover crop treatments. During the cover crop season, we observed a $32-42 \%$ reduction with the inclusion of cover crops.

Currently, Illinois does not regulate application timing and rate of $\mathrm{N}$ fertilizers farmers are able to apply; however, if agriculture continues to be a major contributor to nutrient loading of surface waters, mandatory restrictions on fertilizer management practices could be present in the future. The Illinois Nutrient Loss Reduction Strategy outline voluntary in field practices such as $\mathrm{N}$ fertilizers management practices and the inclusion of cover crops to reduce the amount of nutrients leaving agricultural fields. While studies have shown that applying $\mathrm{N}$ fertilizer in the spring rather than the fall can reduce $\mathrm{N}$ losses, many farmers still fall apply at least a portion of their $\mathrm{N}$ fertilizers. The Illinois Nutrient Loss Reduction Strategy only outlines the use of cover crops in a spring applied fertilizer application system; however, this study shows that cover crops included in a fall management system can be as or more efficient at reducing nutrient losses than just changing $\mathrm{N}$ application timing to the spring. The reductions in nutrient losses seen in this study show that we can increase the efficacy of both fall and spring $\mathrm{N}$ fertilizer management practices used by farmers through the use of cover crops. The use of cover crops in all $\mathrm{N}$ fertilizer management systems reduce agriculture contribution to eutrophication of surface water not only in Illinois, but in many other Midwestern states in the Mississippi River Basin. 


\section{APPENDIX A}

\section{TABLES AND FIGURES FOR CHAPTER III}

Table A-1

Average Monthly Ambient Air Temperature and Total Precipitation 2014 Year and 2015 Year

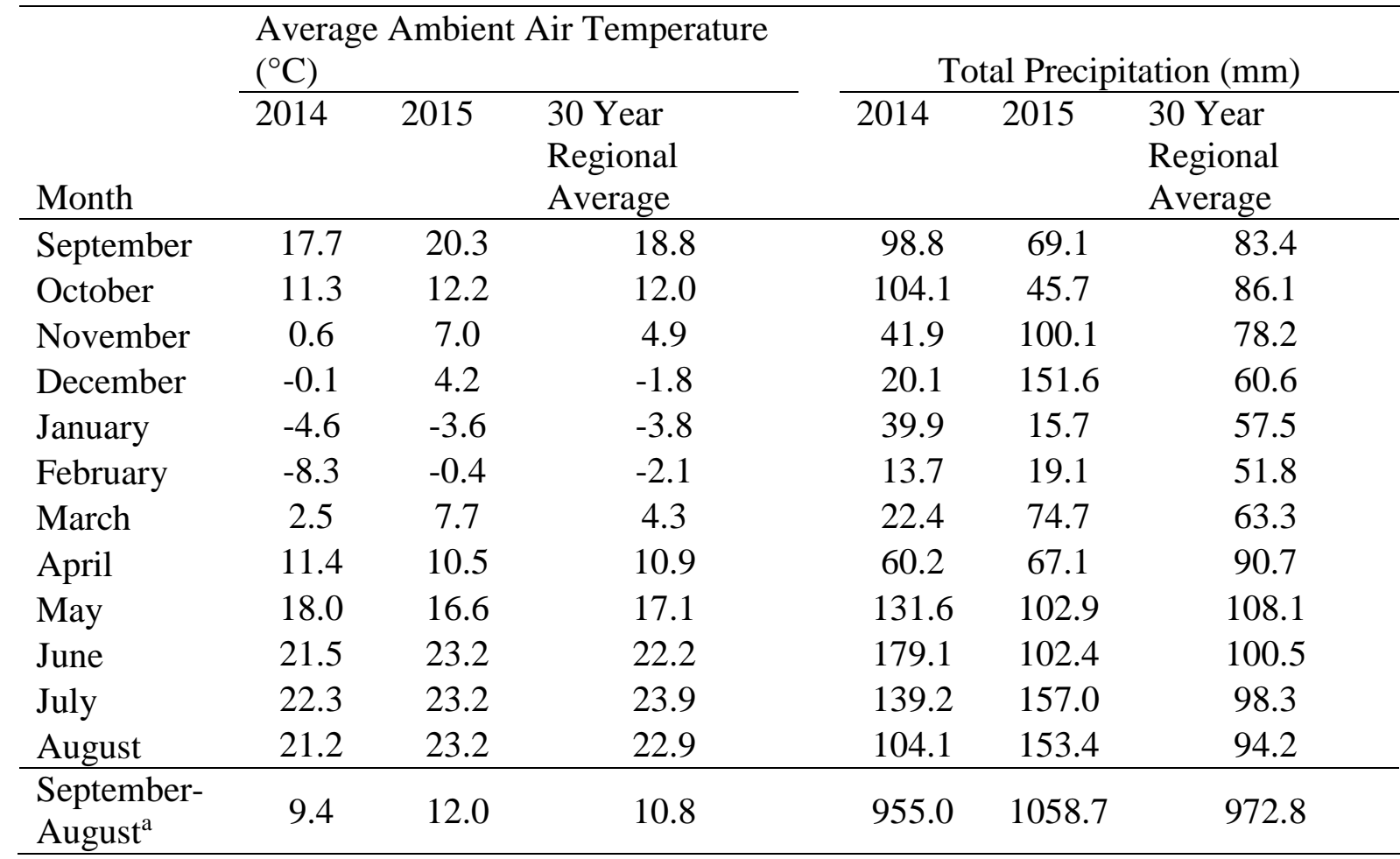

${ }^{a}$ values for the September through August periods are the averages for the period for air temperature and totals for the period for precipitation 
Table A-2

Cover Crop Biomass ANOVA Table

\begin{tabular}{cccc}
\hline Source of Variation & DF & F Value & Pr $>$ F \\
\hline treatment & 2 & 0.15 & 0.7014 \\
Time & 3 & 20.07 & $<.0001$ \\
block & 2 & 0.01 & 0.9923 \\
treatment*sampling & 3 & 0.8 & 0.5134 \\
\hline
\end{tabular}

Note: ANOVA table depicts the response variable (cover crop biomass) and probability values

for each source of variation.

Table A-3

Cover Crop N Uptake AVONA Table

\begin{tabular}{cccc}
\hline Source of Variation & DF & F Value & $\operatorname{Pr}>$ F \\
\hline treatment & 2 & 0.03 & 0.8567 \\
year & 1 & 19.72 & $<.0001$ \\
block & 2 & 0.02 & 0.9803 \\
treatment*sampling & 2 & 1.22 & 0.3395
\end{tabular}

Note: ANOVA table depicts the response variable (cover crop $\mathrm{N}$ uptake) and probability values for each source of variation. 
Table A-4

Average Cover Crop Uptake and Biomass

\begin{tabular}{|c|c|c|c|c|c|c|}
\hline \multirow[b]{2}{*}{$\begin{array}{c}\text { Sampling } \\
\text { Date }\end{array}$} & \multicolumn{3}{|c|}{ Biomass $\left(\mathrm{kg} \mathrm{ha}^{-1}\right)$} & \multicolumn{3}{|c|}{ N Uptake $\left(\mathrm{kg} \mathrm{ha}^{-1}\right)$} \\
\hline & FNCC & SNCC & $\begin{array}{l}\text { Average } \\
\text { Biomass }\end{array}$ & FNCC & SNCC & $\begin{array}{l}\text { Average } \\
\text { Uptake }\end{array}$ \\
\hline 2014 Fall & $\begin{array}{l}332 \\
(51)\end{array}$ & $\begin{array}{l}265 \\
(32)\end{array}$ & $299 b(30.7)$ & $\begin{array}{l}12.3 \\
(1.0)\end{array}$ & $\begin{array}{l}10.9 \\
(1.9)\end{array}$ & $11.6 \mathrm{c}(1.0)$ \\
\hline 2015 Spring & $\begin{array}{l}1,180 \\
(186)\end{array}$ & $\begin{array}{l}1,034 \\
(241)\end{array}$ & $1,107 \mathrm{a}(140.1)$ & $\begin{array}{l}61.5 \\
(9.0)\end{array}$ & $\begin{array}{l}45.6 \\
(9.2)\end{array}$ & $53.5 \mathrm{a}(6.8)$ \\
\hline 2015 Fall & $\begin{array}{l}1,375 \\
(121)\end{array}$ & $\begin{array}{l}1,459 \\
(189)\end{array}$ & $1,417 \mathrm{a}(102.3)$ & $\begin{array}{l}54.9 \\
(5.6)\end{array}$ & $\begin{array}{c}63.9 \\
(10.0)\end{array}$ & $59.4 \mathrm{a}(5.5)$ \\
\hline 2016 Spring & $\begin{array}{l}1,073 \\
(124)\end{array}$ & $\begin{array}{l}1,374 \\
(124)\end{array}$ & $1,223 \mathrm{a}(94.7)$ & $\begin{array}{c}29 \\
(4.4)\end{array}$ & $\begin{array}{l}33.7 \\
(4.6)\end{array}$ & $31.4 b(3.0)$ \\
\hline
\end{tabular}

Note: Values with different letters in a given column are significantly different (Standard Errors

in parenthesis). No significant differences were observed in $\mathrm{N}$ uptake or biomass between the interaction of treatment and sampling date. The Ryan's Multiple comparisons test was used to separate the means. The 2014 fall and 2015 spring sampling dates preceded a corn cash crop and the 2015 fall and 2016 spring preceded a soybean cash crop.

Table A-5

Grain Yield ANOVA

\begin{tabular}{cccc}
\hline Source of Variation & DF & F Value & $\operatorname{Pr}>\mathrm{F}$ \\
\hline treatment & 4 & 339.97 & $<0.0001$ \\
block & 2 & 1.80 & 0.2263
\end{tabular}

Note: ANOVA table depicts the response variable (grain yield) and probability values for each source of variation. 
Table A-6

Cash Crop Yields for the 2015 Corn and 2016 Soybean Cash Crops.

\begin{tabular}{|c|c|c|c|c|c|c|}
\hline \multirow[b]{2}{*}{ Year } & \multirow[b]{2}{*}{$\begin{array}{l}\text { Cash } \\
\text { Crop }\end{array}$} & \multicolumn{5}{|c|}{ Cash Crop Yield } \\
\hline & & Spring & Spring + CC & Fall & Fall + CC & $\begin{array}{c}\text { Zero } \\
\text { Control } \\
\end{array}$ \\
\hline & & \multicolumn{5}{|c|}{$\mathrm{Mg} \mathrm{ha}^{-1}$} \\
\hline 2015 & Corn & $13.27 \mathrm{a}(0.12)$ & $12.35 b(0.3)$ & $12.83 \mathrm{ab}(0.1)$ & $12.82 \mathrm{ab}(0.11)$ & $4.62 \mathrm{c}(0.32)$ \\
\hline 2016 & Soybean & $4.07 \mathrm{a}(0.11)$ & $3.9 \mathrm{a}(0.19)$ & $3.96 \mathrm{a}(0.13)$ & $3.77 \mathrm{a}(0.07)$ & $3.97 \mathrm{a}(0.06)$ \\
\hline
\end{tabular}

Note: Different letters indicate differences between treatments within a cash crop year (standard

error showing in parentheses) at an alpha level of 0.05. Ryan's multiple comparisons test was

used to separate the means. Standard error shown in parentheses.

Table A-7

The Total Nutrient Concentration Within the Whole Soil Profile in the Spring of 2015.

\begin{tabular}{|c|c|c|c|c|c|}
\hline \multicolumn{6}{|c|}{2015 Spring Soil Sampling } \\
\hline Treatment & Spring & Spring + CC & Fall & Fall + CC & Zero Control \\
\hline & \multicolumn{5}{|c|}{$\mathrm{kg} \mathrm{ha}^{-1}$} \\
\hline $\mathrm{NO}_{3}-\mathrm{N}$ & $91.7 \mathrm{a}(4.4)$ & $48.7 \mathrm{a}(1.8)$ & $91.5 a(4.9)$ & $44.7 \mathrm{a}(1.5)$ & $65.8 \mathrm{a}(2.4)$ \\
\hline $\mathrm{NH}_{4}$ & $36.9 \mathrm{a}(2.3)$ & $35.4 \mathrm{~b}(1.9)$ & $50.2 \mathrm{a}(3.1)$ & $38.9 b(2.4)$ & $33 \mathrm{ab}(2.0)$ \\
\hline TIN & $128.6 \mathrm{ab}(6.6)$ & $84.1 \mathrm{~b}(3.3)$ & $141.8 \mathrm{a}(7.6)$ & $83.6 b(3.1)$ & $98.8 \mathrm{ab}(3.7)$ \\
\hline
\end{tabular}

Note: Different letters indicate significant differences between treatments by soil nutrient at an alpha level of 0.05. Ryan's multiple comparisons test was used to separate the means. Standard error shown in parentheses. 
Table A-8

Total Nutrient Content of Soil Profile in the Spring of 2016.

\begin{tabular}{lccccc}
\hline & \multicolumn{5}{c}{ 2016 Spring Soil Sampling } \\
Treatment & Spring & Spring $+\mathrm{CC}$ & Fall & Fall + CC & Zero Control \\
\hline & \multicolumn{5}{c}{$\mathrm{kg} \mathrm{ha}^{-1}$} \\
$\mathrm{NO}_{3}-\mathrm{N}$ & $25.6 \mathrm{a}(0.41)$ & $12.1 \mathrm{~b}(0.54)$ & $25.7 \mathrm{a}(0.73)$ & $17.3 \mathrm{ab}(1.02)$ & $27 \mathrm{a}(0.97)$ \\
$\mathrm{NH}_{4}$ & $15.6 \mathrm{a}(0.93)$ & $19.1 \mathrm{a}(1.37)$ & $15.1 \mathrm{a}(1.13)$ & $14.5 \mathrm{a}(1.09)$ & $12.6 \mathrm{a}(0.90)$ \\
$\mathrm{TIN}$ & $41.2 \mathrm{a}(1.09)$ & $31.2 \mathrm{a}(1.76)$ & $40.9 \mathrm{a}(1.64)$ & $31.8 \mathrm{a}(1.73)$ & $39.6 \mathrm{a}(1.75)$ \\
\hline
\end{tabular}

Note: Different letters indicate significant differences between treatments by soil nutrient at an alpha level of 0.05. Ryan's multiple comparisons test was used to separate the means. Standard error shown in parentheses.

Table A-9

2015 Soil Distribution ( $\left.\mathrm{NO}_{3}-\mathrm{N}\right)$ ANOVA

\begin{tabular}{cccc}
\hline Source of Variation & DF & F Value & Pr > F \\
\hline treatment & 4 & 1.27 & 0.2984 \\
depth & 3 & 30.27 & $<.0001$ \\
block & 2 & 1.18 & 0.3173 \\
treatment*depth & 12 & 0.99 & 0.4723 \\
\hline
\end{tabular}

Note: ANOVA table depicts the response variable $\left(\mathrm{NO}_{3}-\mathrm{N}\right.$ distribution) and probability values for each source of variation. 
Table A-10

2015 Soil Distribution $\left(\mathrm{NH}_{4}\right)$ ANOVA

\begin{tabular}{cccc}
\hline Source of Variation & DF & F Value & Pr > F \\
\hline treatment & 4 & 5.46 & 0.0014 \\
depth & 3 & 16.17 & $<.0001$ \\
block & 2 & 0.60 & 0.5562 \\
treatment*depth & 12 & 1.23 & 0.3010 \\
\hline
\end{tabular}

Note: ANOVA table depicts the response variable $\left(\mathrm{NH}_{4}\right.$ distribution) and probability values for each source of variation.

Table A-11

2015 Soil Distribution (TIN) ANOVA

\begin{tabular}{cccc}
\hline Source of Variation & DF & F Value & Pr > F \\
\hline treatment & 4 & 3.84 & 0.0103 \\
depth & 3 & 25.39 & $<.0001$ \\
block & 2 & 0.94 & 0.3986 \\
treatment*depth & 12 & 1.11 & 0.3842
\end{tabular}

Note: ANOVA table depicts the response variable (TIN distribution) and probability values for each source of variation. 
Table A-12

2016 Soil Distribution ( $\left.\mathrm{NO}_{3}-\mathrm{N}\right)$ ANOVA

\begin{tabular}{cccc}
\hline Source of Variation & DF & F Value & Pr $>$ F \\
\hline treatment & 4 & 10.86 & $<.0001$ \\
depth & 3 & 20.48 & $<.0001$ \\
block & 2 & 5.65 & 0.0071 \\
treatment*depth & 12 & 1.88 & 0.0691
\end{tabular}

Note: ANOVA table depicts the response variable $\left(\mathrm{NO}_{3}-\mathrm{N}\right.$ distribution) and probability values for each source of variation.

Table A-13

2016 Soil Distribution $\left(\mathrm{NH}_{4}\right)$ ANOVA

\begin{tabular}{cccc}
\hline Source of Variation & DF & F Value & Pr > F \\
\hline treatment & 4 & 1.20 & 0.3265 \\
depth & 3 & 60.33 & $<.0001$ \\
block & 2 & 1.32 & 0.2790 \\
treatment*depth & 12 & 0.55 & 0.8654
\end{tabular}

Note: ANOVA table depicts the response variable $\left(\mathrm{NH}_{4}\right.$ distribution) and probability values for each source of variation. 
Table A-14

2016 Soil Distribution (TIN) ANOVA

\begin{tabular}{cccc}
\hline Source of Variation & DF & F Value & $\operatorname{Pr}>$ F \\
\hline treatment & 4 & 3.99 & 0.0085 \\
depth & 3 & 102.08 & $<.0001$ \\
block & 2 & 2.50 & 0.0959 \\
treatment*depth & 12 & 1.57 & 0.1414
\end{tabular}

Note: ANOVA table depicts the response variable (TIN distribution) and probability values for each source of variation.

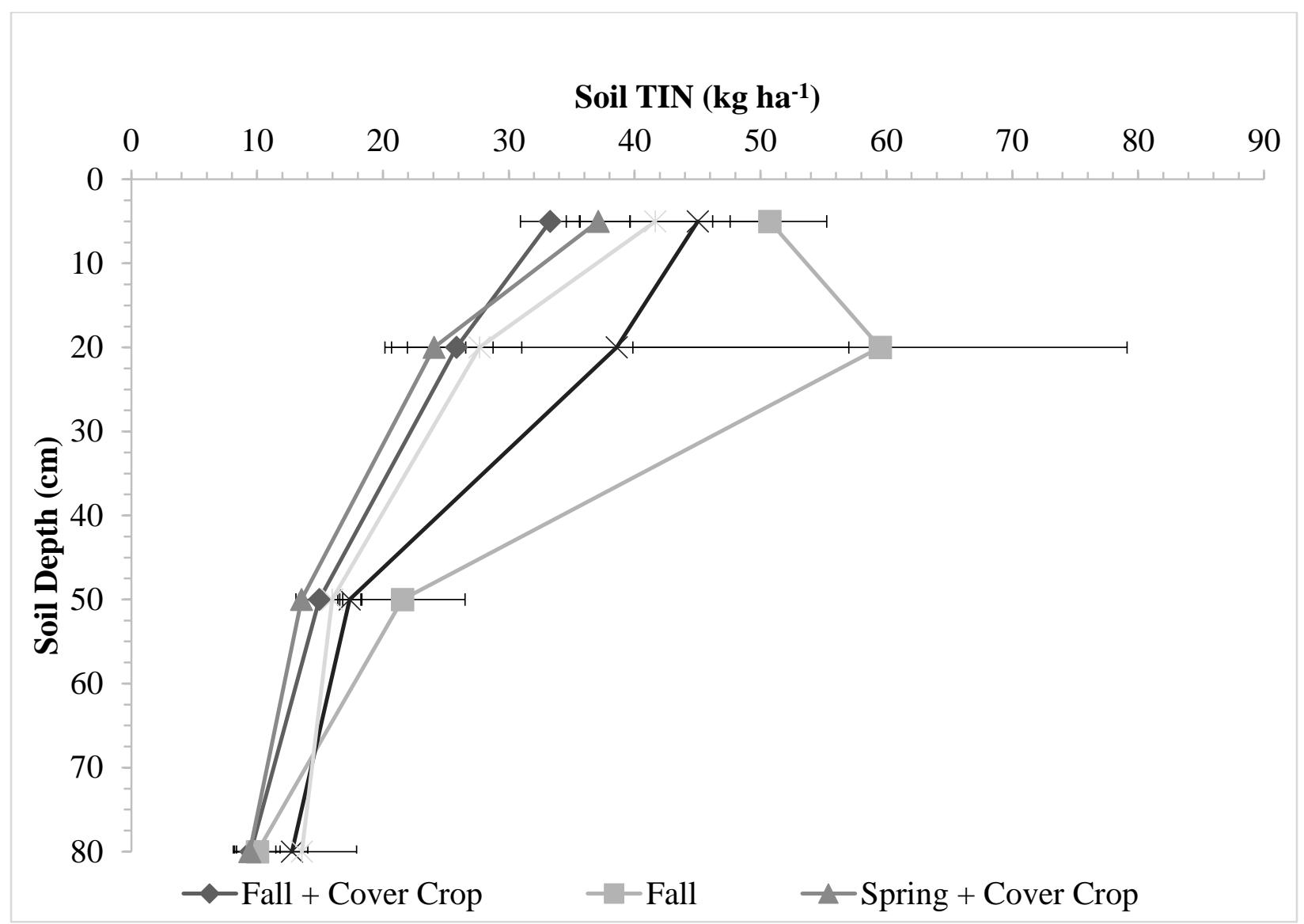

Figure A-1. Soil total inorganic $\mathrm{N}\left(\mathrm{kg} \mathrm{ha}^{-1}\right)$ by depth $(\mathrm{cm})$ collected in spring of 2015. The error bars represent the standard errors. 


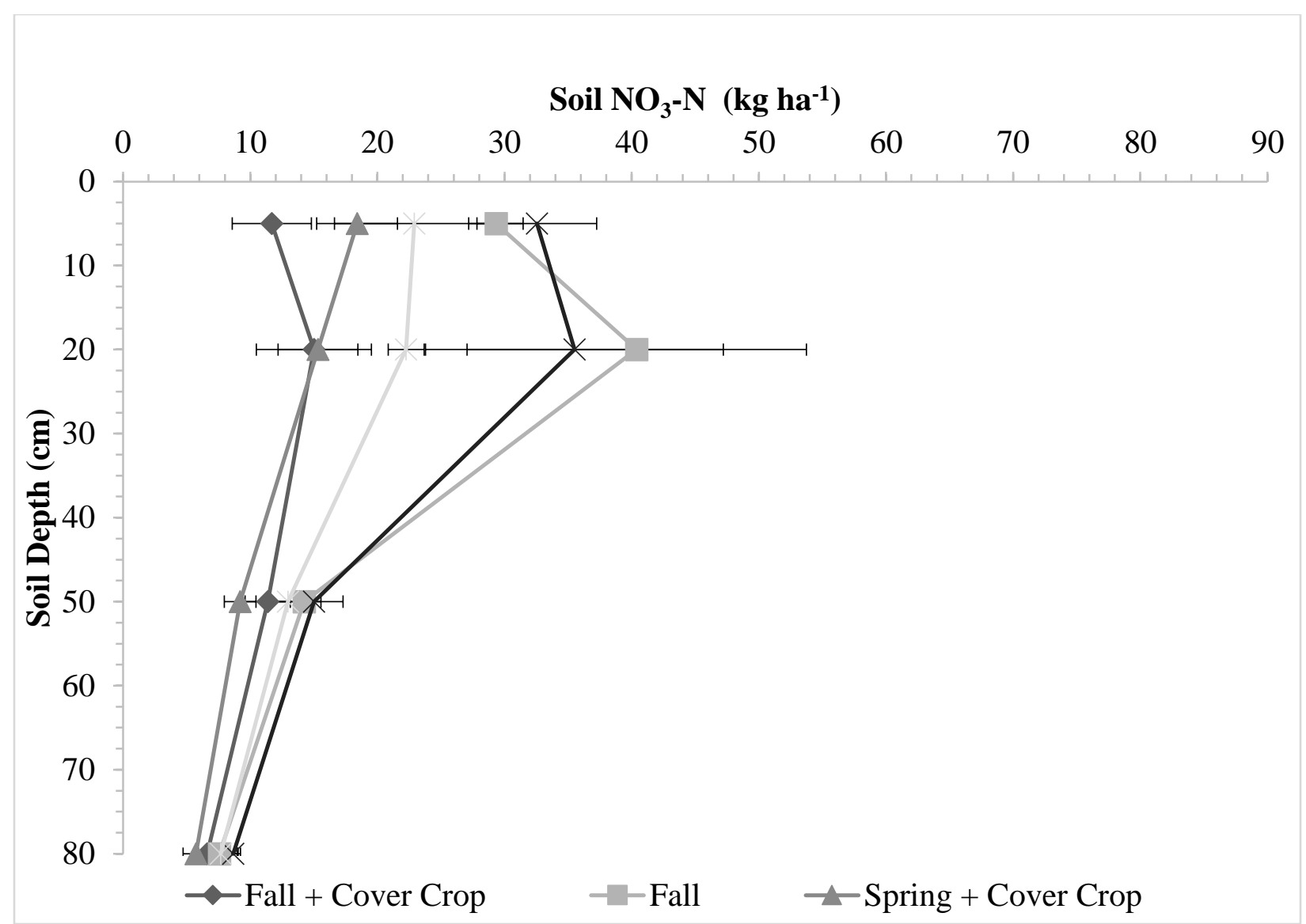

Figure A-2. Soil nitrate $\left(\mathrm{kg} \mathrm{ha}^{-1}\right)$ by depth $(\mathrm{cm})$ collected in spring of 2015 . The error bars represent the standard errors. 


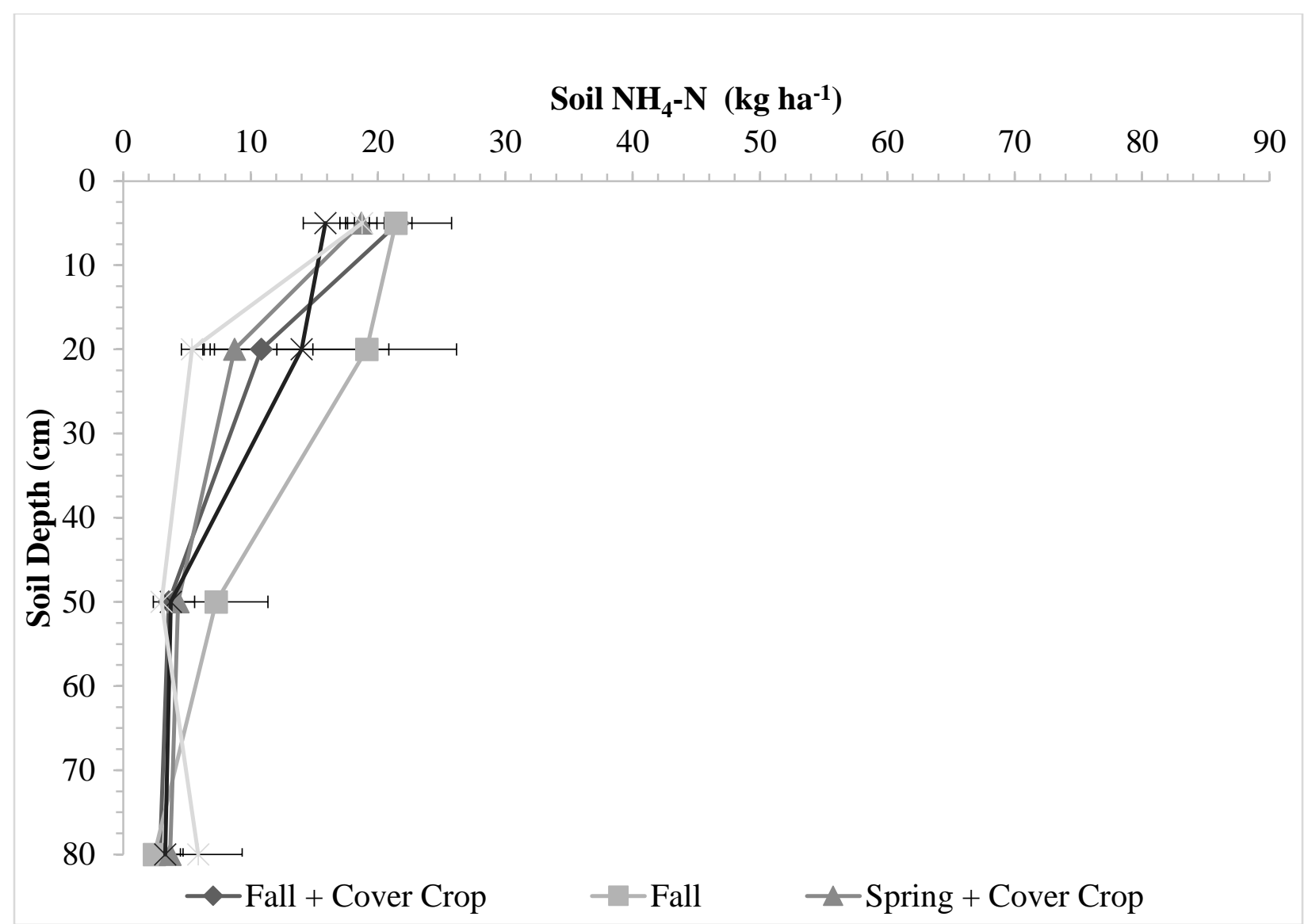

Figure A-3. Soil ammonium $\left(\mathrm{kg} \mathrm{ha}^{-1}\right)$ by depth $(\mathrm{cm})$ collected in spring of 2015 . The error bars represent the standard errors. 


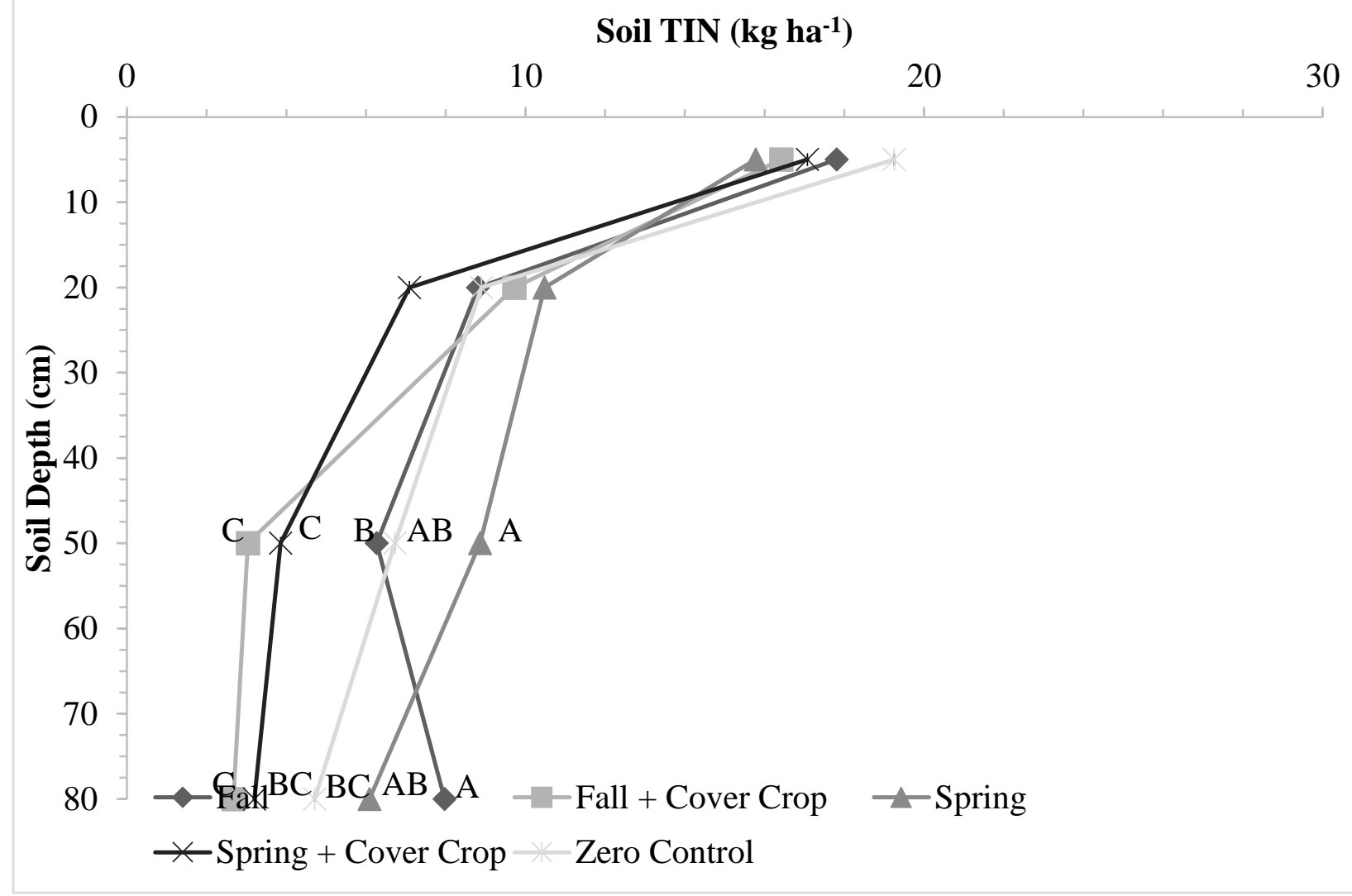

Figure A-4. Soil total inorganic N $\left(\mathrm{kg} \mathrm{ha}^{-1}\right)$ by depth $(\mathrm{cm})$ collected in spring of 2016. Different letters as each depth indicate significant difference at an alpha level of 0.05 . The error bars represent the standard errors. 


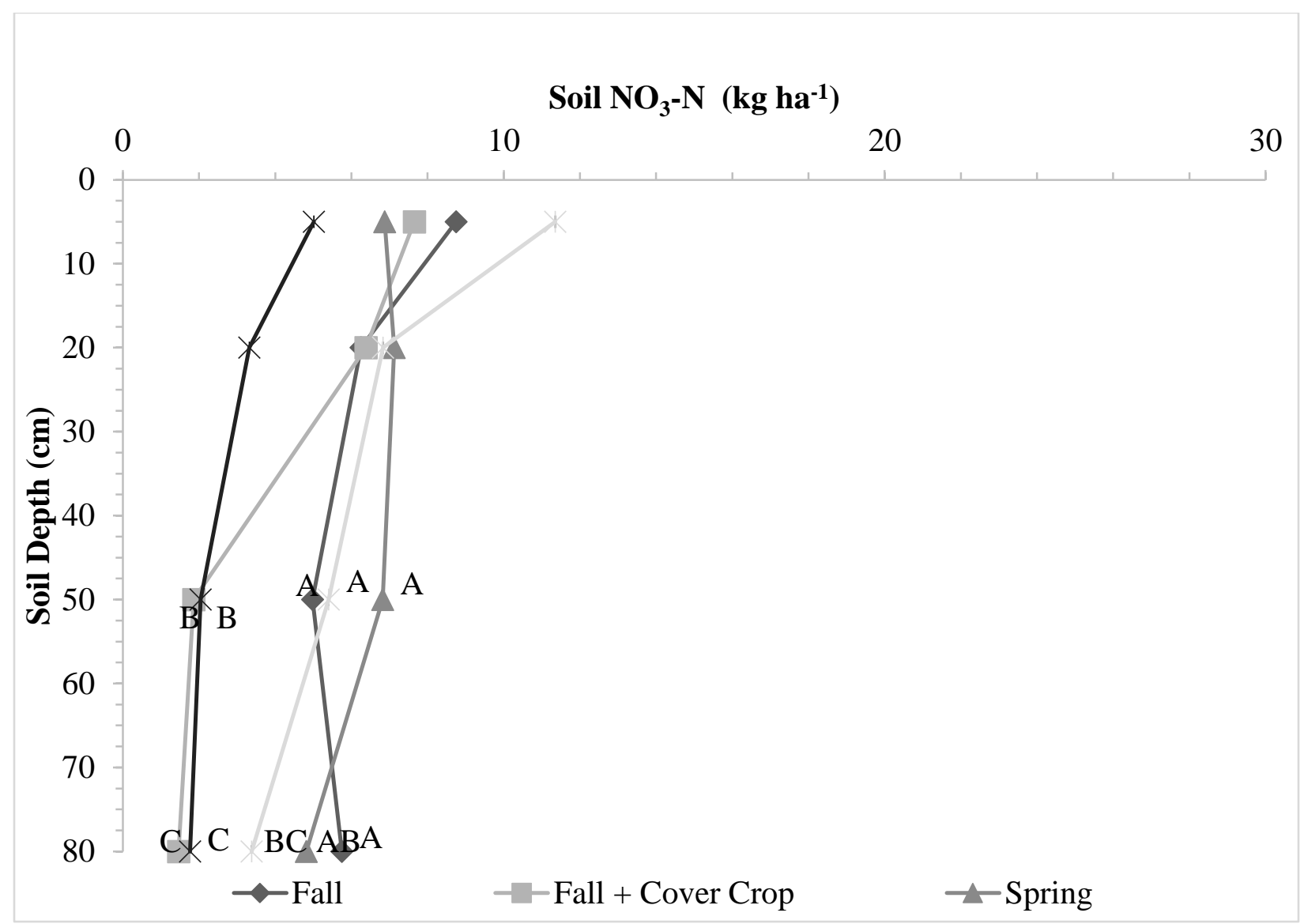

Figure A-5. Soil nitrate $\left(\mathrm{kg} \mathrm{ha}^{-1}\right)$ by depth $(\mathrm{cm})$ collected in spring of 2016. Different letters as each depth indicate significant difference at an alpha level of 0.05 . The error bars represent the standard errors. 


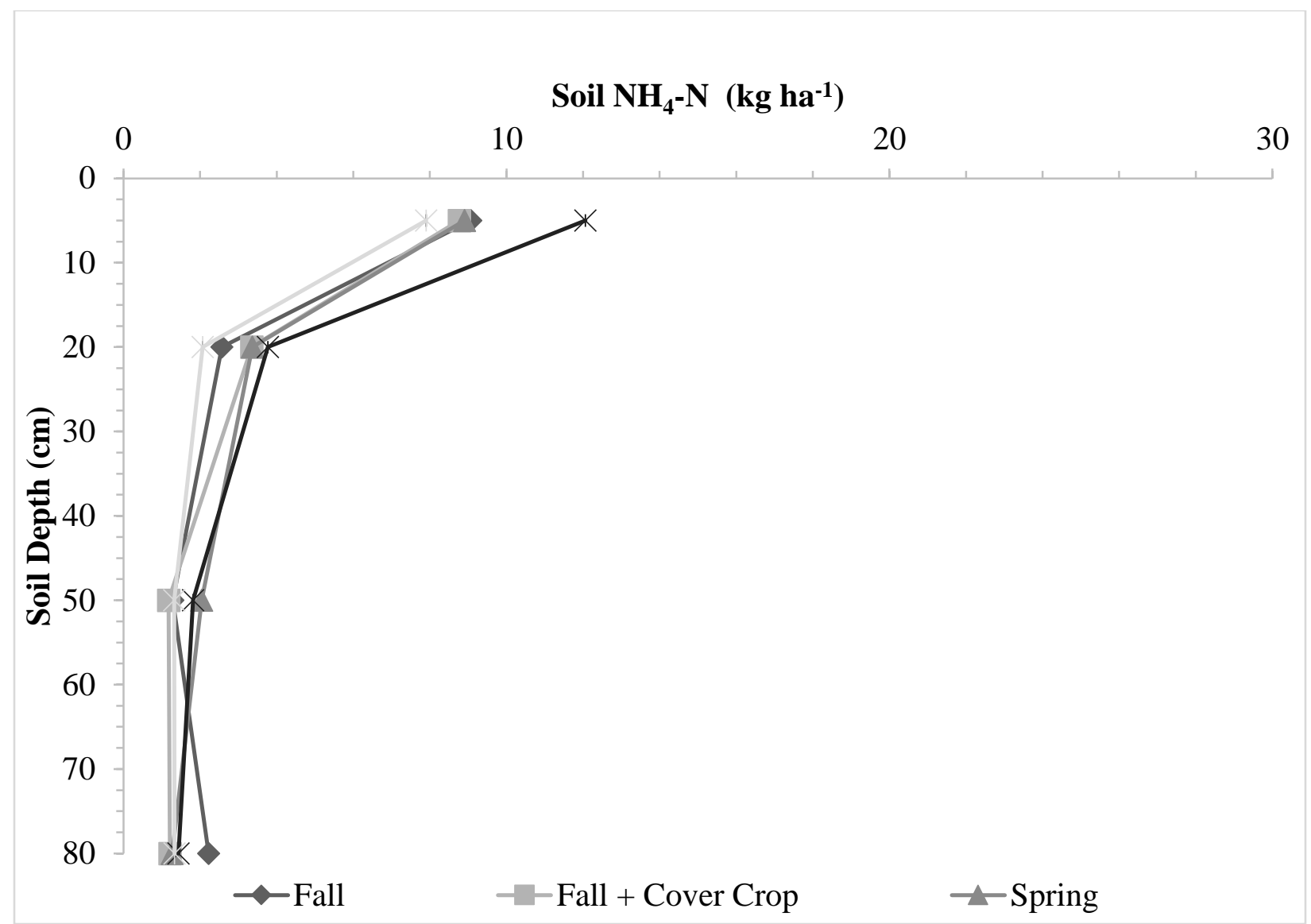

Figure A-6. Soil ammonium $\left(\mathrm{kg} \mathrm{ha}^{-1}\right)$ by depth $(\mathrm{cm})$ collected in spring of 2016. The error bars represent the standard errors. 


\section{APPENDIX B}

TABLES AND FIGURES FOR CHAPTER IV

Table B-1

Average Monthly Ambient Air Temperature and Total Precipitation 2014 Year and 2015 Year

\begin{tabular}{|c|c|c|c|c|c|c|}
\hline \multirow[b]{2}{*}{ Month } & \multicolumn{3}{|c|}{$\begin{array}{l}\text { Average Ambient Air Temperature } \\
\left({ }^{\circ} \mathrm{C}\right)\end{array}$} & \multicolumn{3}{|c|}{ Total Precipitation (mm) } \\
\hline & 2014 & 2015 & $\begin{array}{l}30 \text { Year } \\
\text { Regional } \\
\text { Average }\end{array}$ & 2014 & 2015 & $\begin{array}{l}30 \text { Year } \\
\text { Regional } \\
\text { Average }\end{array}$ \\
\hline September & 17.7 & 20.3 & 18.8 & 98.8 & 69.1 & 83.4 \\
\hline October & 11.3 & 12.2 & 12.0 & 104.1 & 45.7 & 86.1 \\
\hline November & 0.6 & 7.0 & 4.9 & 41.9 & 100.1 & 78.2 \\
\hline December & -0.1 & 4.2 & -1.8 & 20.1 & 151.6 & 60.6 \\
\hline January & -4.6 & -3.6 & -3.8 & 39.9 & 15.7 & 57.5 \\
\hline February & -8.3 & -0.4 & -2.1 & 13.7 & 19.1 & 51.8 \\
\hline March & 2.5 & 7.7 & 4.3 & 22.4 & 74.7 & 63.3 \\
\hline April & 11.4 & 10.5 & 10.9 & 60.2 & 67.1 & 90.7 \\
\hline May & 18.0 & 16.6 & 17.1 & 131.6 & 102.9 & 108.1 \\
\hline June & 21.5 & 23.2 & 22.2 & 179.1 & 102.4 & 100.5 \\
\hline July & 22.3 & 23.2 & 23.9 & 139.2 & 157.0 & 98.3 \\
\hline August & 21.2 & 23.2 & 22.9 & 104.1 & 153.4 & 94.2 \\
\hline $\begin{array}{l}\text { September- } \\
\text { August }^{\mathrm{a}}\end{array}$ & 9.4 & 12.0 & 10.8 & 955.0 & 1058.7 & 972.8 \\
\hline
\end{tabular}


Table B-2

Cover Crop Biomass ANOVA Table

\begin{tabular}{cccc}
\hline Source of Variation & DF & F Value & Pr > F \\
\hline treatment & 2 & 0.15 & 0.7014 \\
sampling & 3 & 20.07 & $<.0001$ \\
block & 2 & 0.01 & 0.9923 \\
treatment*sampling & 3 & 0.8 & 0.5134 \\
\hline
\end{tabular}

Note: ANOVA table depicts the response variable (cover crop biomass) and probability values for each source of variation.

Table B-3

Cover Crop N Uptake AVONA Table

\begin{tabular}{cccc}
\hline Source of Variation & DF & F Value & Pr $>$ F \\
\hline treatment & 2 & 0.03 & 0.8567 \\
year & 1 & 19.72 & $<0.0001$ \\
block & 2 & 0.02 & 0.9803 \\
treatment*sampling & 2 & 1.22 & 0.3395
\end{tabular}

Note: ANOVA table depicts the response variable (cover crop $\mathrm{N}$ uptake) and probability values for each source of variation. 
Table B-4

Average Cover Crop Uptake and Biomass

\begin{tabular}{|c|c|c|c|c|c|c|}
\hline \multirow[b]{2}{*}{$\begin{array}{c}\text { Sampling } \\
\text { Date }\end{array}$} & \multicolumn{3}{|c|}{ Biomass $\left(\mathrm{kg} \mathrm{ha}^{-1}\right)$} & \multicolumn{3}{|c|}{ N Uptake $\left(\mathrm{kg} \mathrm{ha}^{-1}\right)$} \\
\hline & FNCC & SNCC & $\begin{array}{l}\text { Average } \\
\text { Biomass }\end{array}$ & FNCC & SNCC & $\begin{array}{l}\text { Average } \\
\text { Uptake }\end{array}$ \\
\hline 2014 Fall & $\begin{array}{l}332 \\
(51)\end{array}$ & $\begin{array}{l}265 \\
(32)\end{array}$ & $299 b(30.7)$ & $\begin{array}{l}12.3 \\
(1.0)\end{array}$ & $\begin{array}{l}10.9 \\
(1.9)\end{array}$ & $11.6 \mathrm{c}(1.0)$ \\
\hline 2015 Spring & $\begin{array}{l}1,180 \\
(186)\end{array}$ & $\begin{array}{l}1,034 \\
(241)\end{array}$ & $1,107 \mathrm{a}(140.1)$ & $\begin{array}{l}61.5 \\
(9.0)\end{array}$ & $\begin{array}{l}45.6 \\
(9.2)\end{array}$ & $53.5 \mathrm{a}(6.8)$ \\
\hline 2015 Fall & $\begin{array}{l}1,375 \\
(121)\end{array}$ & $\begin{array}{l}1,459 \\
(189)\end{array}$ & $1,417 \mathrm{a}(102.3)$ & $\begin{array}{l}54.9 \\
(5.6)\end{array}$ & $\begin{array}{c}63.9 \\
(10.0)\end{array}$ & $59.4 \mathrm{a}(5.5)$ \\
\hline 2016 Spring & $\begin{array}{l}1,073 \\
(124)\end{array}$ & $\begin{array}{l}1,374 \\
(124)\end{array}$ & $1,223 \mathrm{a}(94.7)$ & $\begin{array}{c}29 \\
(4.4)\end{array}$ & $\begin{array}{l}33.7 \\
(4.6)\end{array}$ & $31.4 \mathrm{~b}(3.0)$ \\
\hline
\end{tabular}

Note: Values with different letters in a given column are significantly different (standard errors in parenthesis). No significant differences were observed in $\mathrm{N}$ uptake or biomass between the interaction of treatment and sampling date. The Ryan's Multiple comparisons test was used to separate the means.

Table B-5

Grain Yield ANOVA

\begin{tabular}{cccc}
\hline Source of Variation & DF & F Value & Pr $>$ F \\
\hline treatment & 4 & 339.97 & $<0.0001$ \\
block & 2 & 1.80 & 0.2263
\end{tabular}

Note: ANOVA table depicts the response variable (grain yield) and probability values for each source of variation. 
Table B-6

Cash Crop Yields for the 2015 Corn and 2016 Soybean Cash Crops.

\begin{tabular}{|c|c|c|c|c|c|c|}
\hline \multirow[b]{2}{*}{ Year } & \multirow[b]{2}{*}{$\begin{array}{l}\text { Cash } \\
\text { Crop }\end{array}$} & \multicolumn{5}{|c|}{ Cash Crop Yield } \\
\hline & & Spring & $\begin{array}{c}\text { Spring + } \\
\text { CC }\end{array}$ & Fall & Fall + CC & $\begin{array}{c}\text { Zero } \\
\text { Control }\end{array}$ \\
\hline & & \multicolumn{5}{|c|}{$\mathrm{Mg} \mathrm{ha}^{-1}$} \\
\hline 2015 & Corn & $13.27 \mathrm{a}(0.12)$ & $12.35 b(0.3)$ & 12.83ab (0.1) & $12.82 \mathrm{ab}(0.11)$ & $4.62 \mathrm{c}(0.32)$ \\
\hline 2016 & Soybean & $4.07 \mathrm{a}(0.11)$ & 3.9a (0.19) & $3.96 a(0.13)$ & $3.77 \mathrm{a}(0.07)$ & $3.97 \mathrm{a}(0.06)$ \\
\hline
\end{tabular}

Note: Different letters indicate differences between treatments within a cash crop year (standard

error showing in parentheses) at an alpha level of 0.05. Ryan's multiple comparisons test was used to separate the means. Standard error shown in parentheses.

Table B-7

Multivariate ANOVA for $\mathrm{NO}_{3}^{-} \mathrm{NLoad}^{-}$Flow-weighted $\mathrm{NO}_{3}^{-} \mathrm{N}, \mathrm{NH}_{4}$ Load, Flow-weighted $\mathrm{NH}_{4}$, DRP Load, Flow-weighted DRP, and Total Discharge

\begin{tabular}{cccc}
\hline Source of Variation & DF & F Value & Pr>f \\
\hline Treatment & 28 & 1.79 & 0.0171 \\
Season & 21 & 6.38 & $<0.0001$ \\
Block & 14 & 4.81 & $<0.0001$ \\
Treatment* Season & 84 & 0.86 & 0.7928 \\
Treatment*Year & 28 & 2.82 & 0.6848 \\
\hline
\end{tabular}

Note: ANOVA table depicts the response variables and probability values for each source of variation. 
Table B- 8

ANOVA table for nitrate load between treatments

\begin{tabular}{cccc}
\hline Source of Variation & DF & F Value & Pr>f \\
\hline Treatment & 4 & 1.3 & 0.286 \\
Season & 3 & 9.2 & 0.0001 \\
Year & 3 & 0.44 & 0.5132 \\
Error & 38 & & \\
\hline
\end{tabular}

Note: ANOVA table depicts the response variable (nitrate load) and probability values for each source of variation.

Table B-9

ANOVA Table for Flow-Weighted Nitrate Concentration between Treatments

\begin{tabular}{cccc}
\hline Source of Variation & DF & F Value & Pr $>\mathrm{f}$ \\
\hline Treatment & 4 & 3.74 & 0.0116 \\
Season & 3 & 33 & $<0.0001$ \\
Year & 3 & 8.42 & 0.0095 \\
Error & 38 & & \\
\hline
\end{tabular}

Note: ANOVA table depicts the response variable (flow-weighted nitrate concentration) and probability values for each source of variation.

Table B-10

ANOVA Table for Ammonium Load between Treatments

\begin{tabular}{cccc}
\hline Source of Variation & DF & F Value & Pr $>\mathrm{f}$ \\
\hline Treatment & 4 & 1.33 & 0.2772 \\
Season & 3 & 11.84 & $<0.0001$ \\
Year & 3 & 0.72 & 0.4087 \\
Error & 38 & & \\
\hline
\end{tabular}

Note: ANOVA table depicts the response variable (ammonium load) and probability values for each source of variation. 
Table B-11

ANOVA Table for Flow-Weighted Ammonium Concentration between Treatments

\begin{tabular}{cccc}
\hline Source of Variation & DF & F Value & Pr $>\mathrm{f}$ \\
\hline Treatment & 4 & 1.11 & 0.3673 \\
Season & 3 & 15.75 & $<0.0001$ \\
Year & 3 & 35.83 & $<0.0001$ \\
Error & 38 & & \\
\hline
\end{tabular}

Note: ANOVA table depicts the response variable (flow-weighted ammonium concentration) and probability values for each source of variation.

Table B-12

ANOVA Table for Dissolved Reactive Phosphorus Load between Treatments

\begin{tabular}{cccc}
\hline Source of Variation & DF & F Value & Pr $>\mathrm{f}$ \\
\hline Treatment & 4 & 1.29 & 0.2896 \\
Season & 3 & 9.39 & $<0.0001$ \\
Year & 3 & 0.00 & 0.9849 \\
Error & 38 & & \\
\hline
\end{tabular}

Note: ANOVA table depicts the response variable (grain yield) and probability values for each source of variation. 
Table B-13

ANOVA Table for Flow-Weighted Dissolved Reactive Phosphorus Concentration between

Treatments

\begin{tabular}{cccc}
\hline Source of Variation & DF & F Value & Pr>f \\
\hline Treatment & 4 & 0.6 & 0.6663 \\
Season & 3 & 1.55 & 0.2178 \\
Year & 3 & 3.17 & 0.0919 \\
Error & 38 & & \\
\hline
\end{tabular}

Note: ANOVA table depicts the response variable (grain yield) and probability values for each source of variation.

Table B-14

ANOVA Table for Total Tile Drainage Discharge between Treatments

\begin{tabular}{cccc}
\hline Source of Variation & DF & F Value & Pr $>\mathrm{f}$ \\
\hline Treatment & 4 & 1.87 & 0.1359 \\
Season & 3 & 7.08 & 0.0007 \\
Year & 3 & 6.60 & 0.0193 \\
Error & 38 & & \\
\hline
\end{tabular}

Note: ANOVA table depicts the response variable (grain yield) and probability values for each source of variation. 


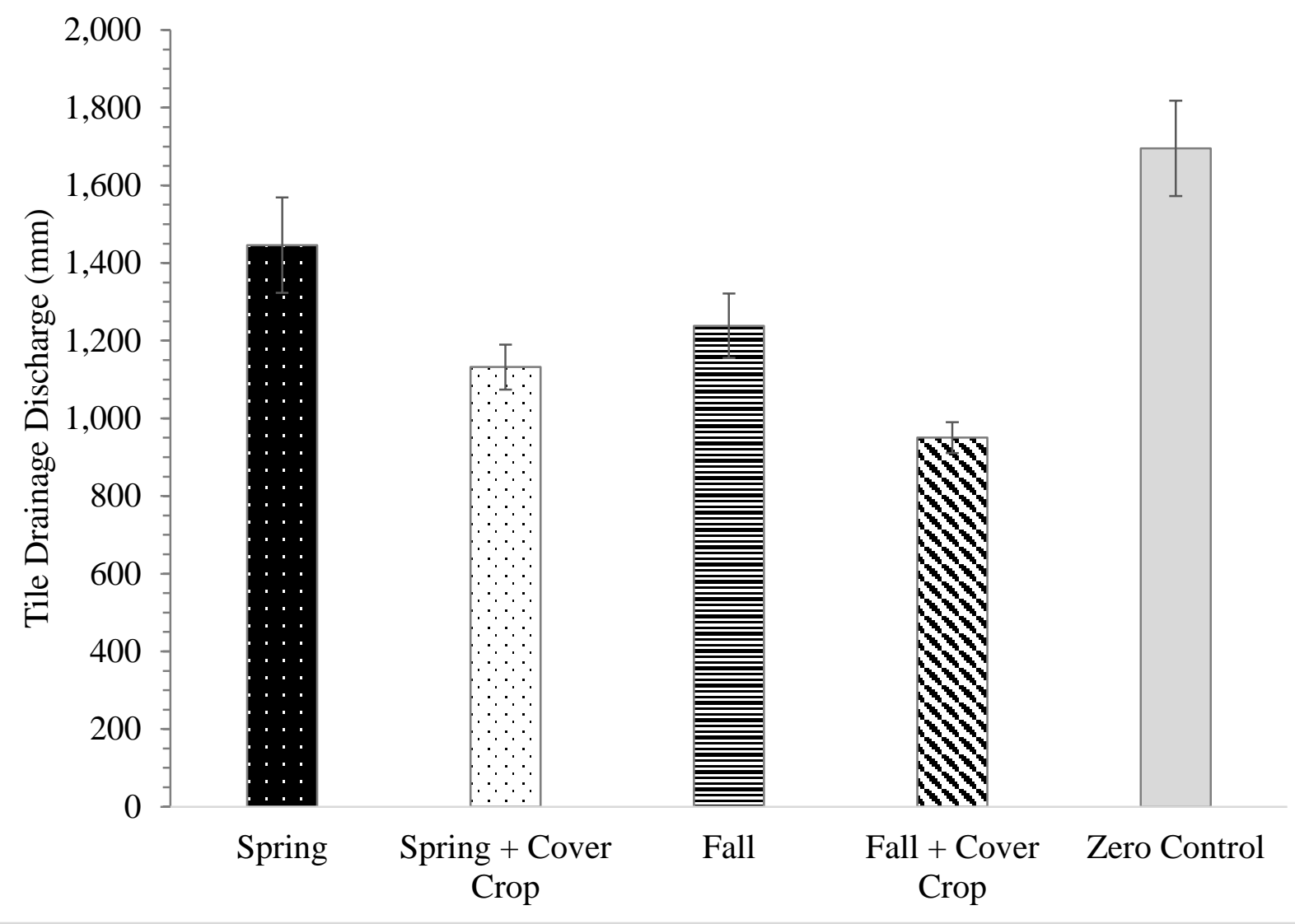

Figure B-1. Average subsurface tile drainage discharge for each treatment from across the course of the study. Error bars represent the standard error. 


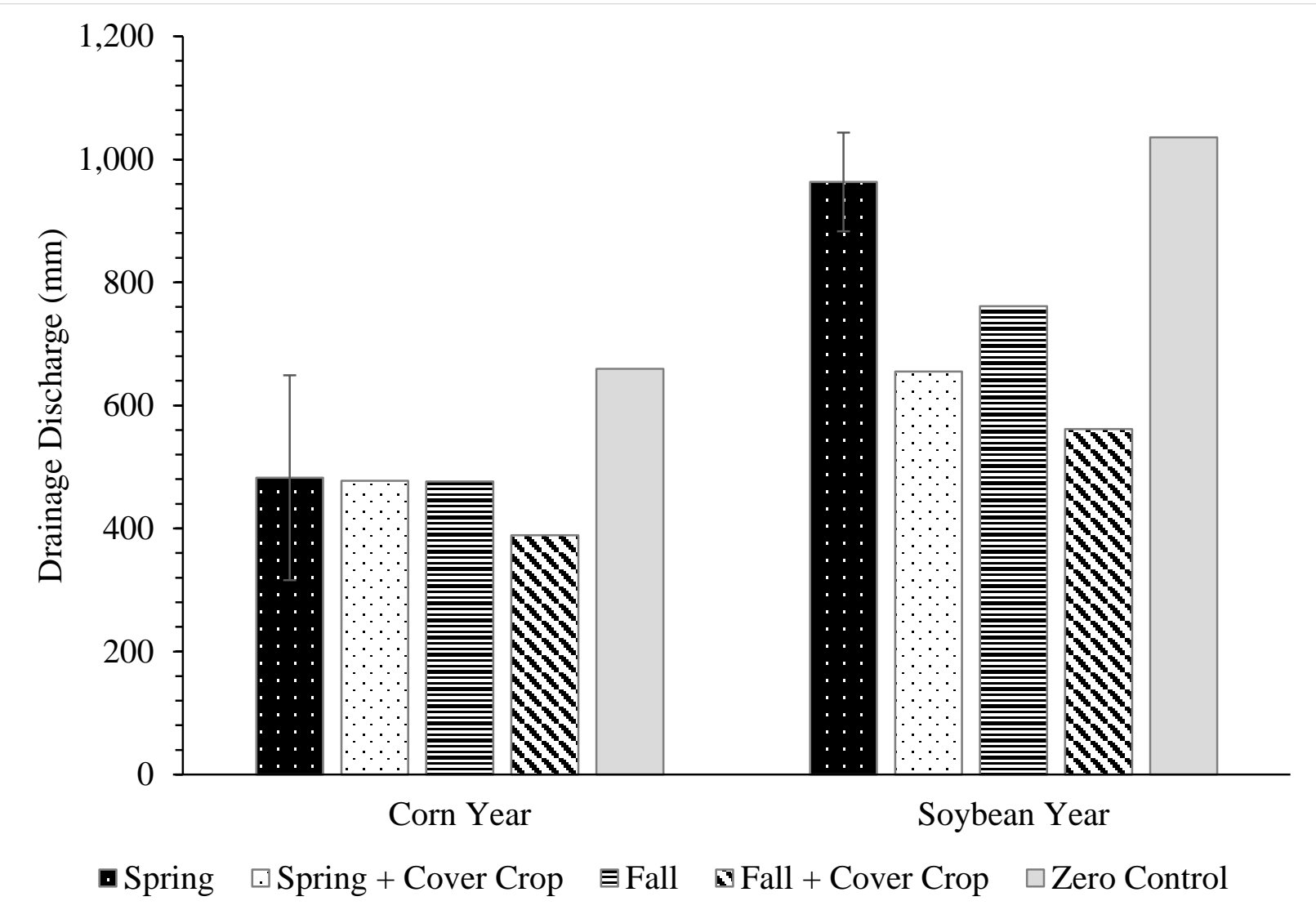

Figure B-2. Cumulative tile drainage discharge for each treatment in the 2015 corn year and the 2016 soybean year. Error bars represent the standard error. 


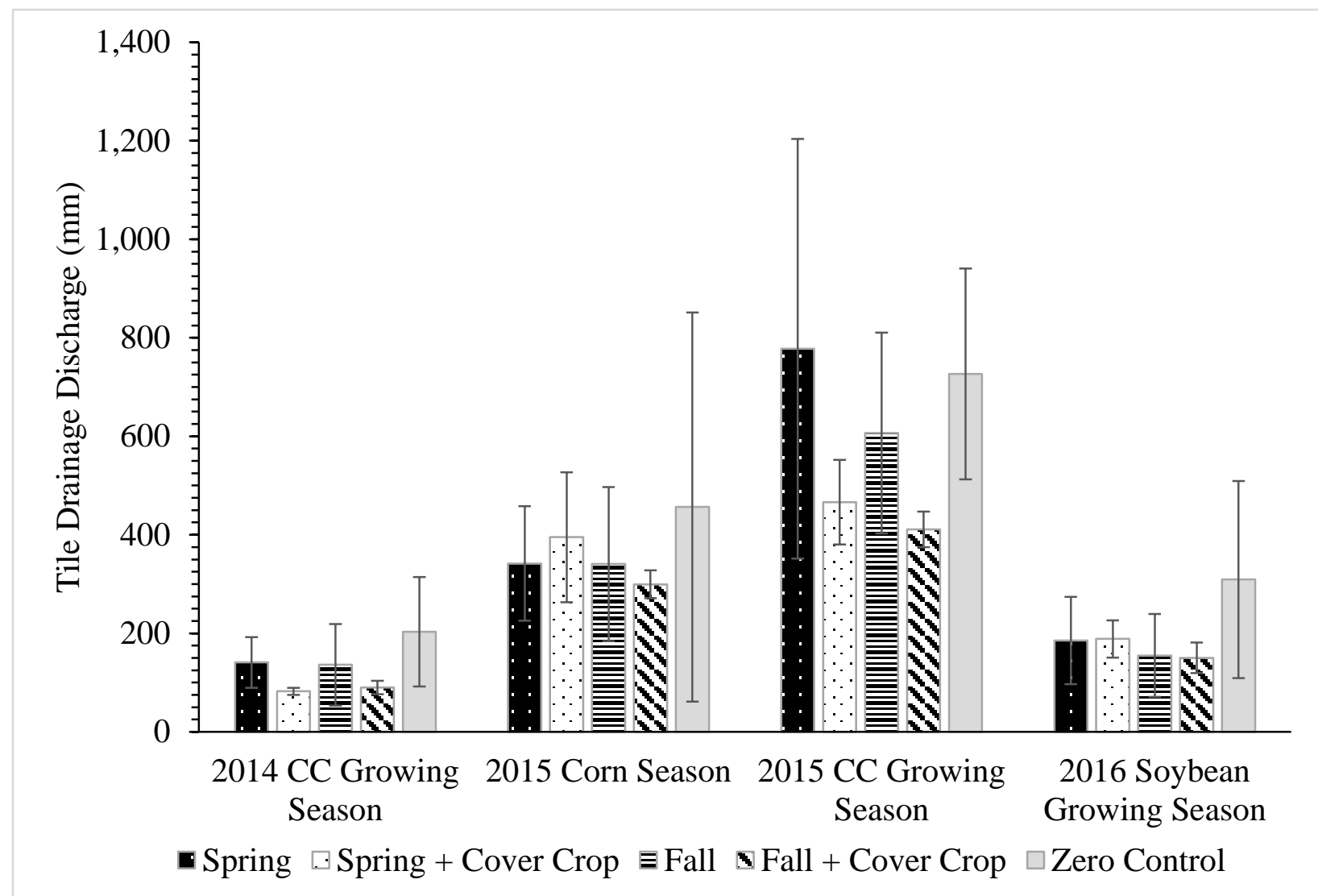

Figure B-3. Cumulative tile drainage discharge by season for each of the treatments. Error bars represent the standard error. 


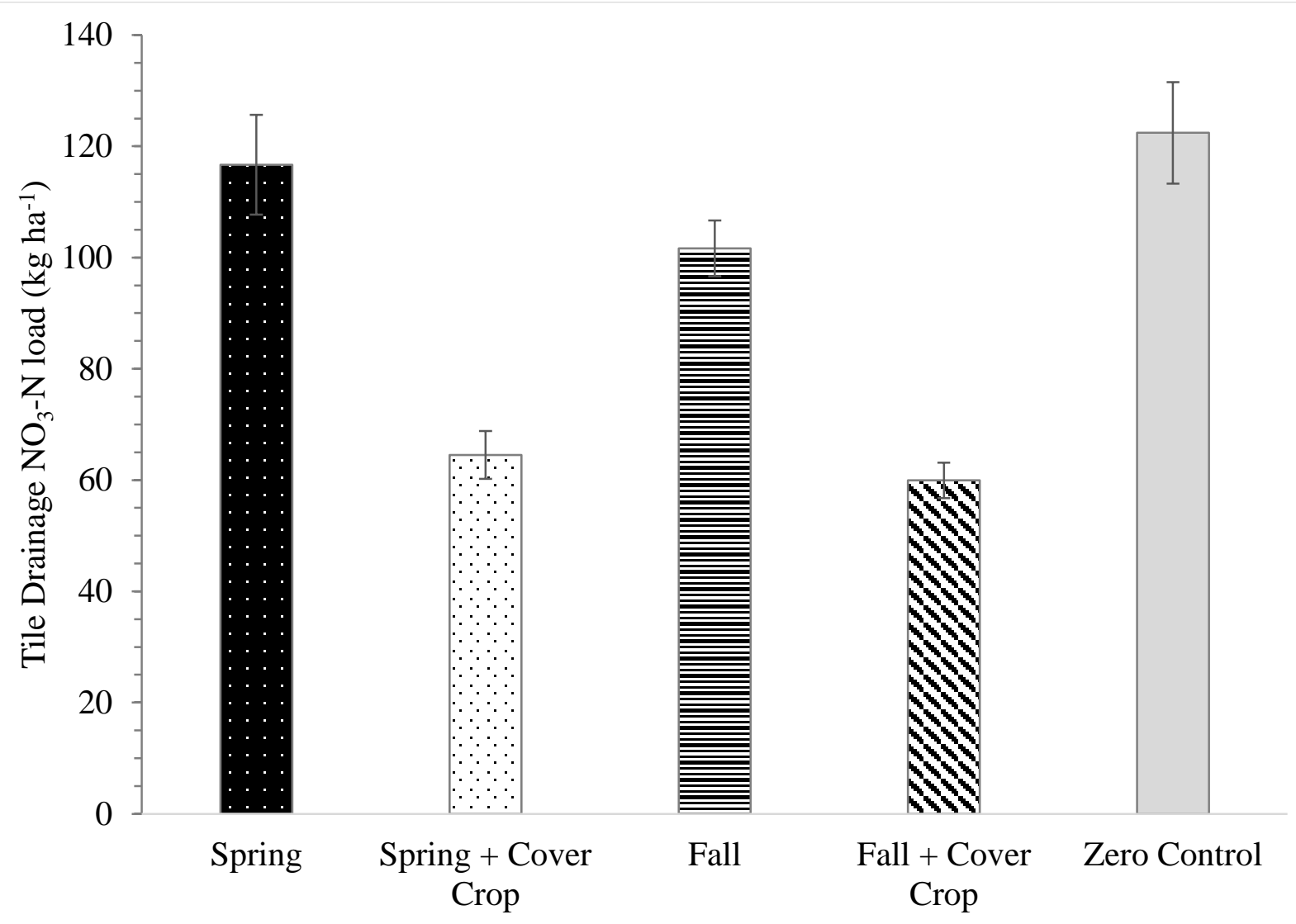

Figure B-4. Total $\mathrm{NO}_{3}-\mathrm{N}$ load of the tile drainage for each treatment from across the course of the study. Error bars represent the standard error. 


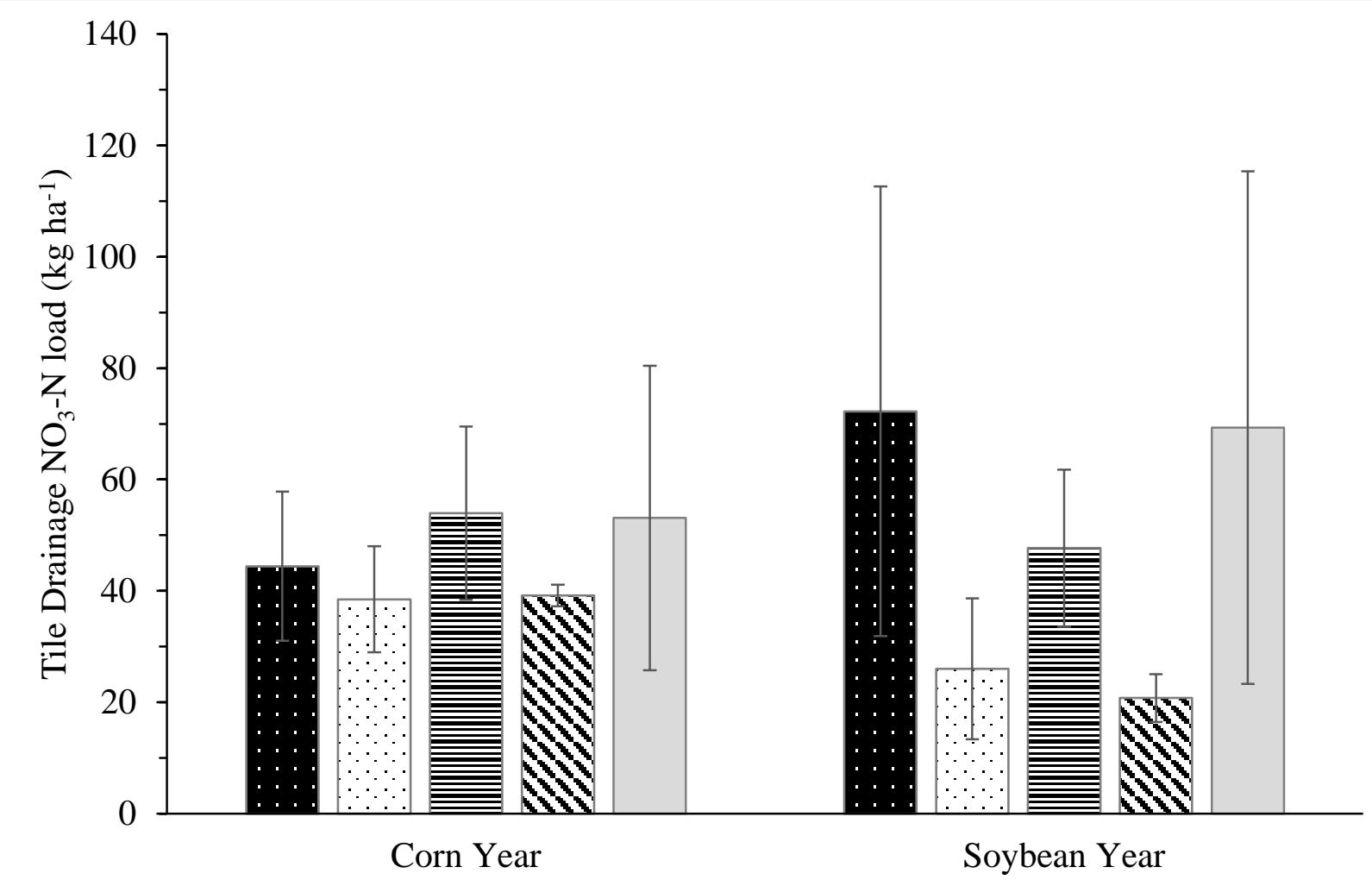

- Spring $\square$ Spring + Cover Crop $\equiv$ Fall $\quad$ sall + Cover Crop $\square$ Zero Control

Figure B-5. Cumulative $\mathrm{NO}_{3}-\mathrm{N}$ load for each treatment within the 2015 corn and 2016 soybean year. Error bars represent the standard error. 


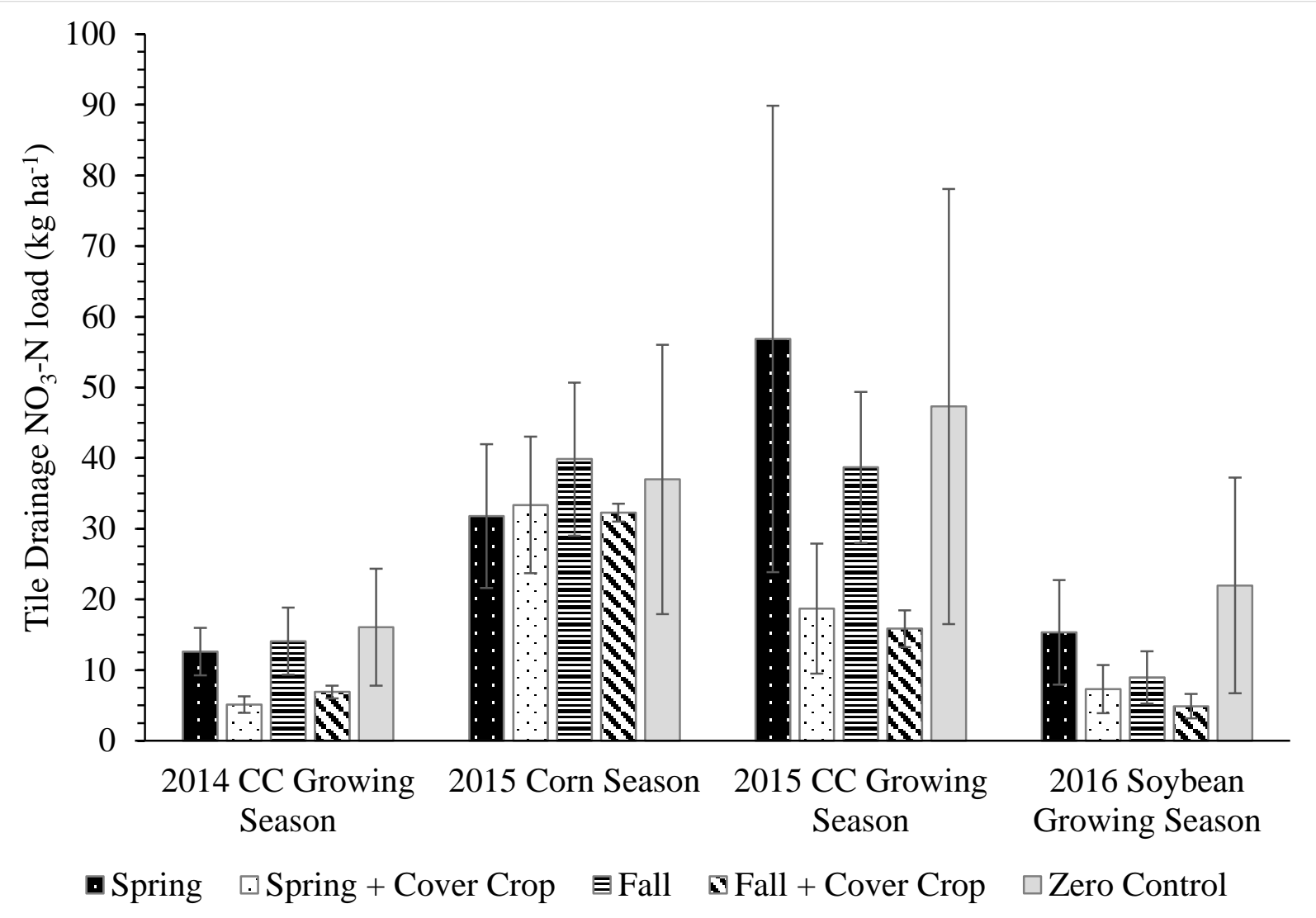

Figure B-6. Cumulative $\mathrm{NO}_{3}-\mathrm{N}$ load for each treatment within the each season. Error bars represent the standard error. 


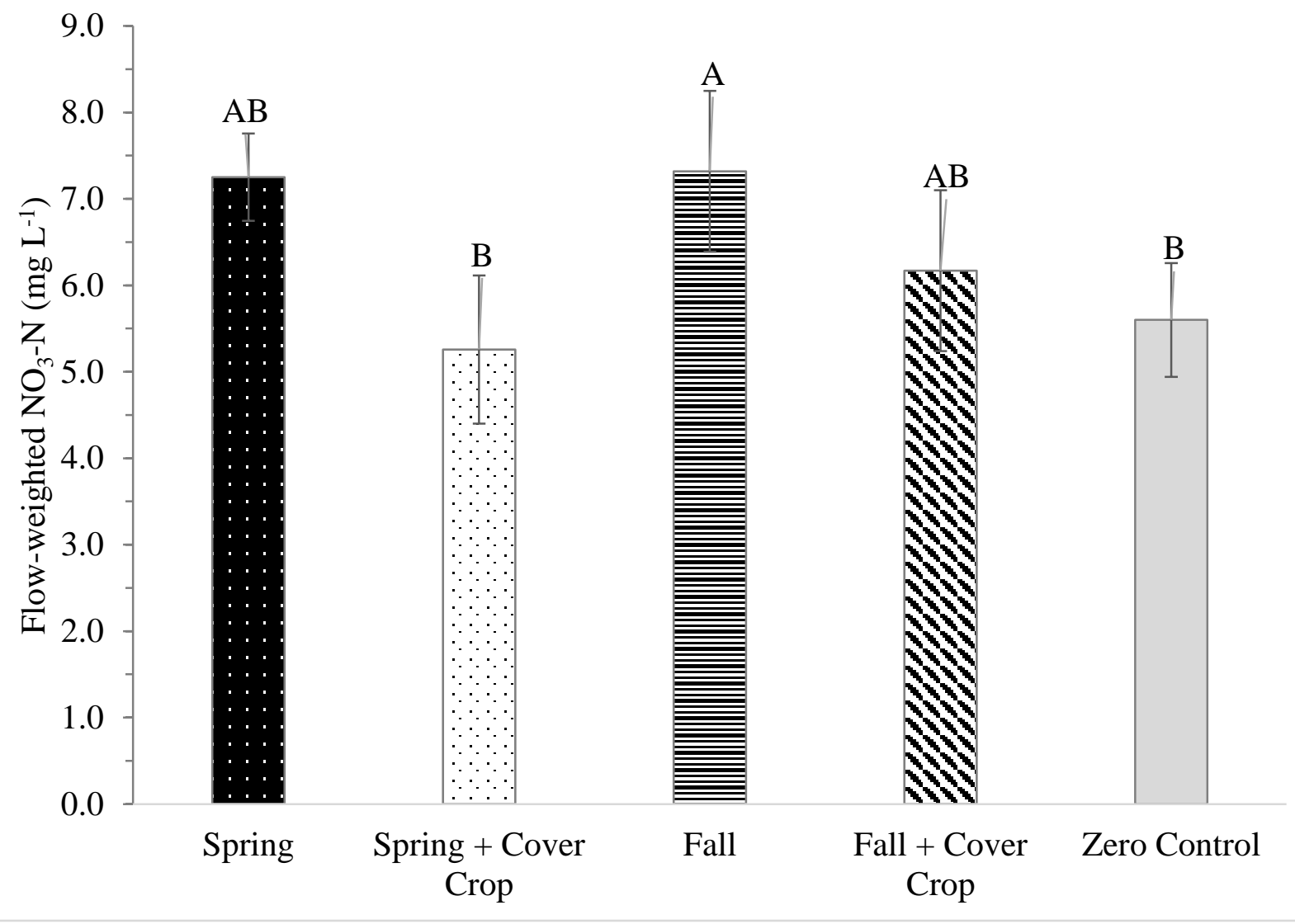

Figure B-7. Average flow-weighted $\mathrm{NO}_{3}-\mathrm{N}$ concentration for each treatment across the course of the study. Different letters indicate significant differences between treatments at an alpha level of 0.05 according to Ryan's multiple comparisons test. Error bars represent the standard error. 


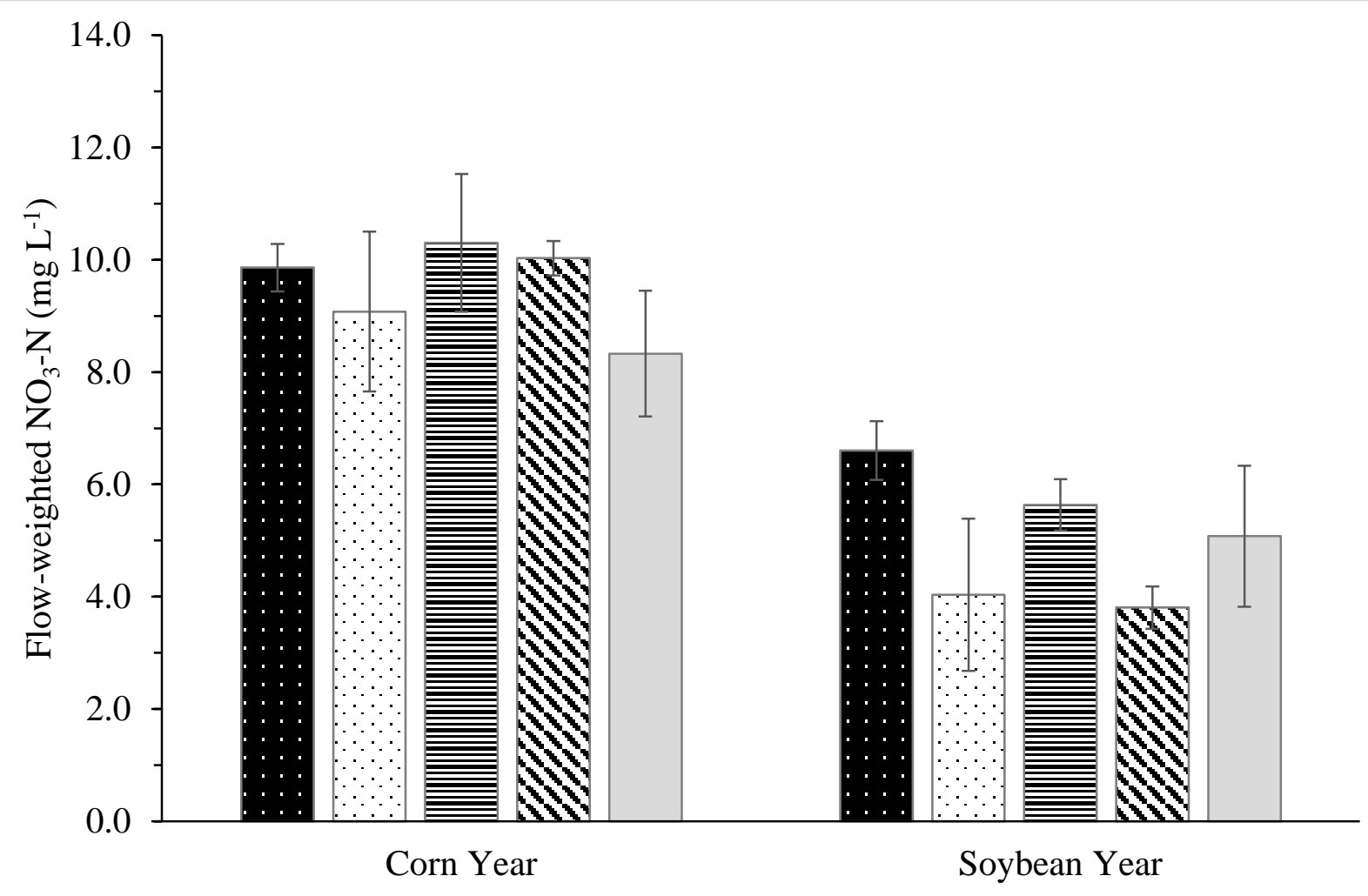

- Spring $\square$ Spring + Cover Crop $\equiv$ Fall $\quad$ Fall + Cover Crop $\square$ Zero Control

Figure B-8. Average flow-weighted $\mathrm{NO}_{3}-\mathrm{N}$ concentration for each treatment in the 2015 corn and 2016 soybean year. Error bars represent the standard error. 


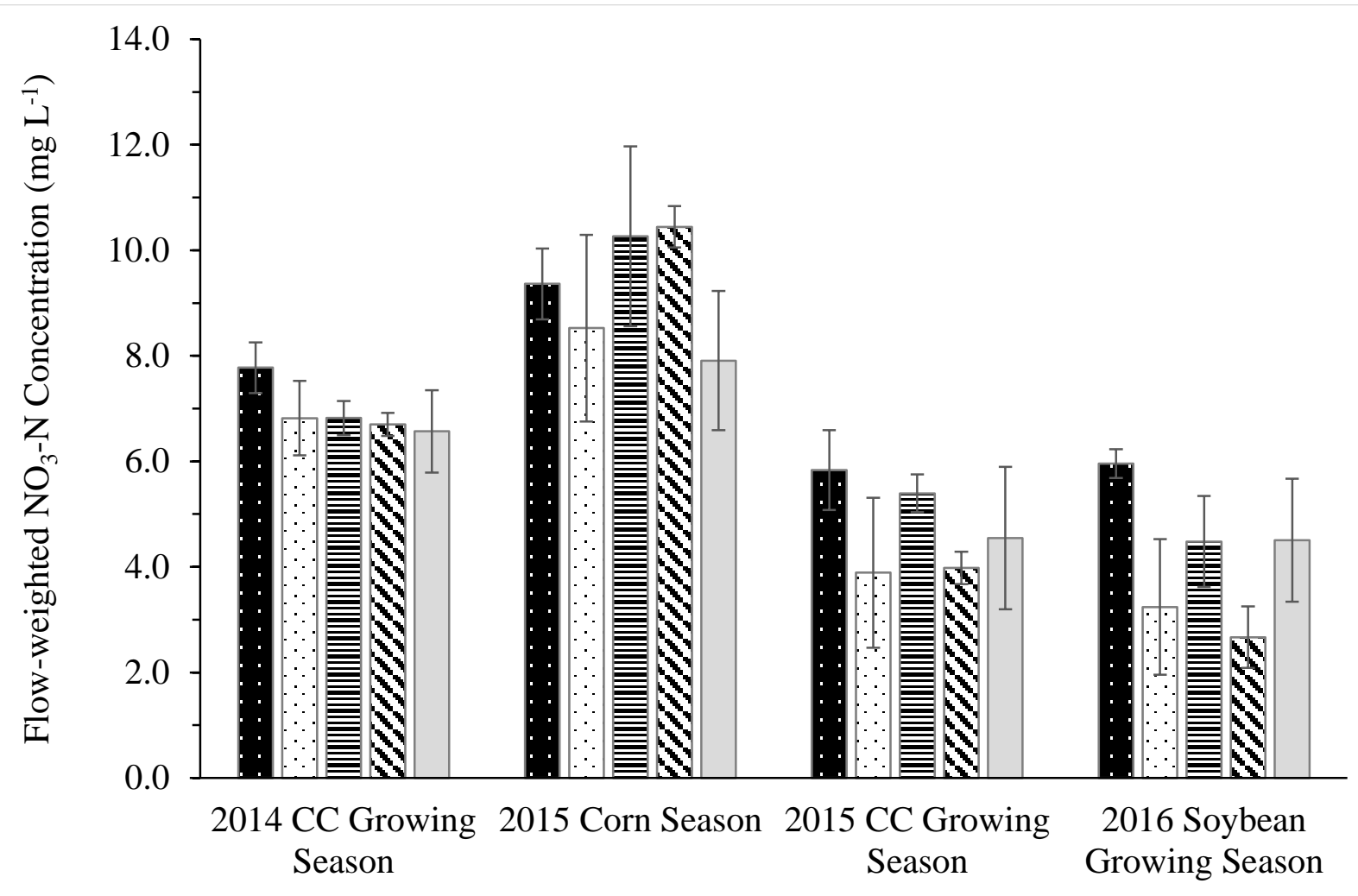

- Spring $\square$ Spring + Cover Crop $\quad$ EFall $\quad$ Fall + Cover Crop $\square$ Zero Control

Figure B-9. Average flow-weighted $\mathrm{NO}_{3}-\mathrm{N}$ concentration for each treatment within each season.

Error bars represent the standard error. 


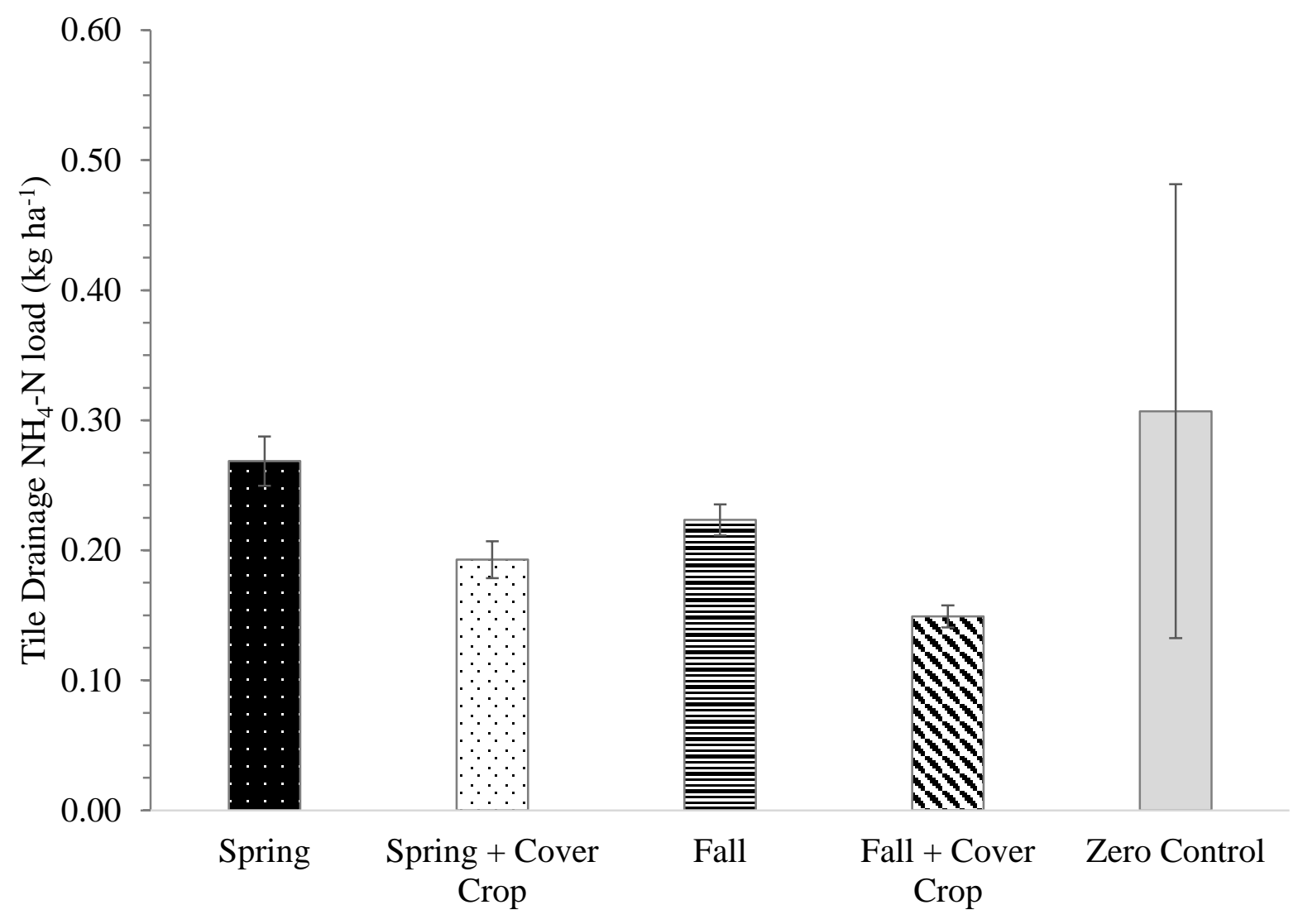

Figure $B$-10. Total $\mathrm{NH}_{4}-\mathrm{N}$ load of the tile drainage for each treatment from across the course of the study. Error bars represent the standard error. 


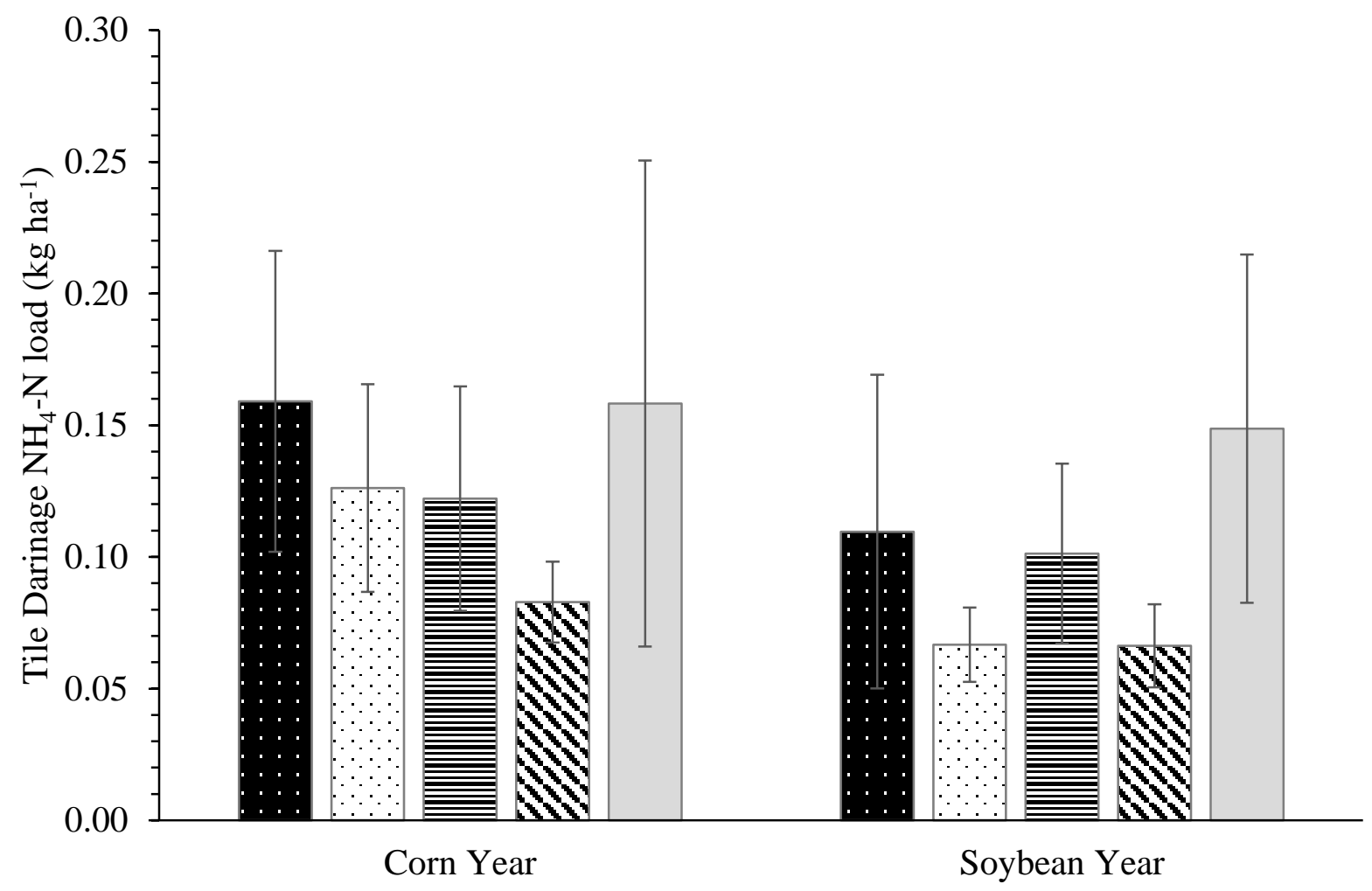

- Spring $\square$ Spring + Cover Crop $\equiv$ Fall $\quad \checkmark$ Fall + Cover Crop $\square$ Zero Control

Figure B-11. Cumulative $\mathrm{NH}_{4}{ }^{-} \mathrm{N}$ load for each treatment within the 2015 corn and 2016 soybean year. Error bars represent the standard error. 


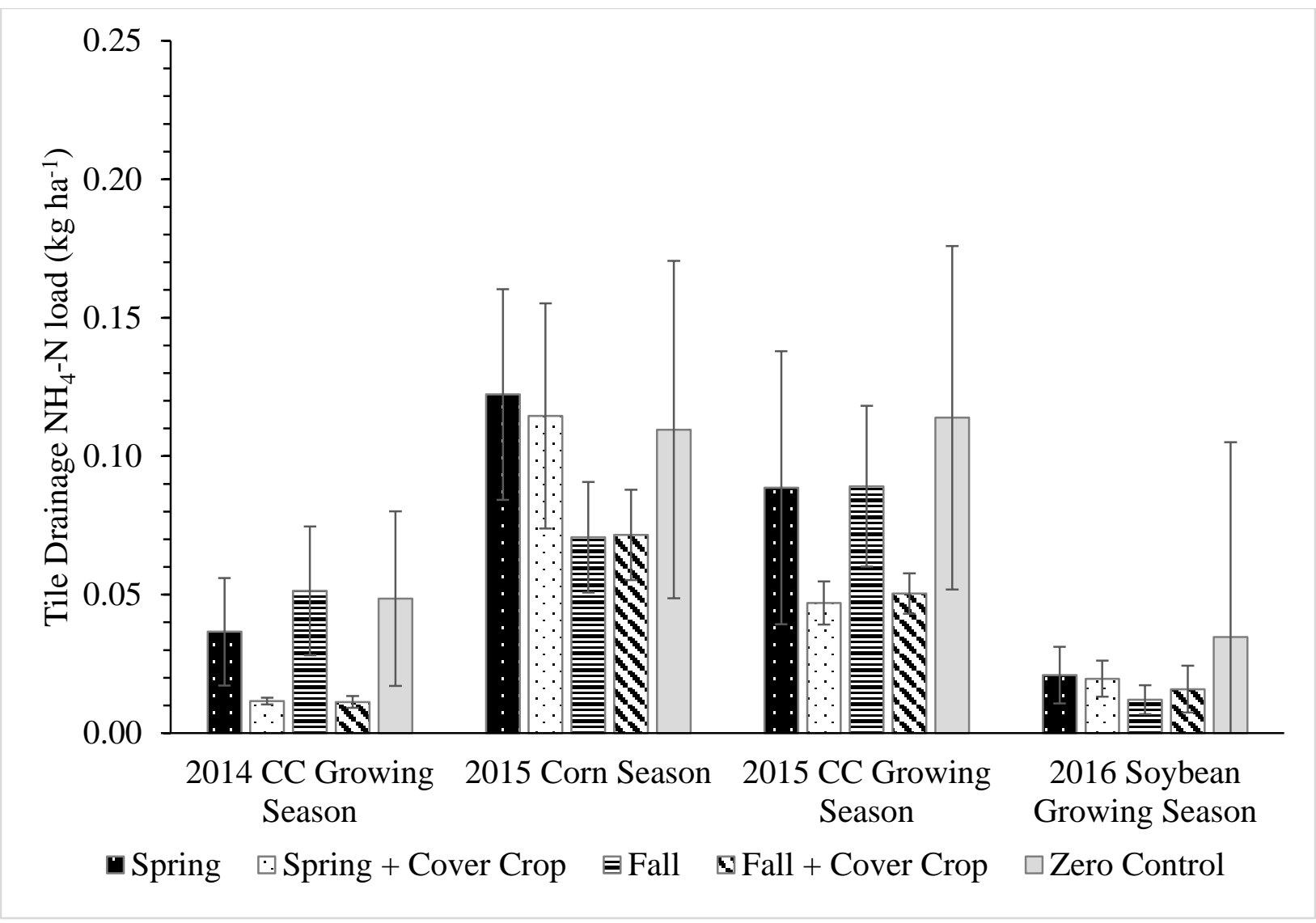

Figure B-12. Cumulative $\mathrm{NH}_{4}^{-} \mathrm{N}$ load for each treatment within the each season. Error bars represent the standard error. 


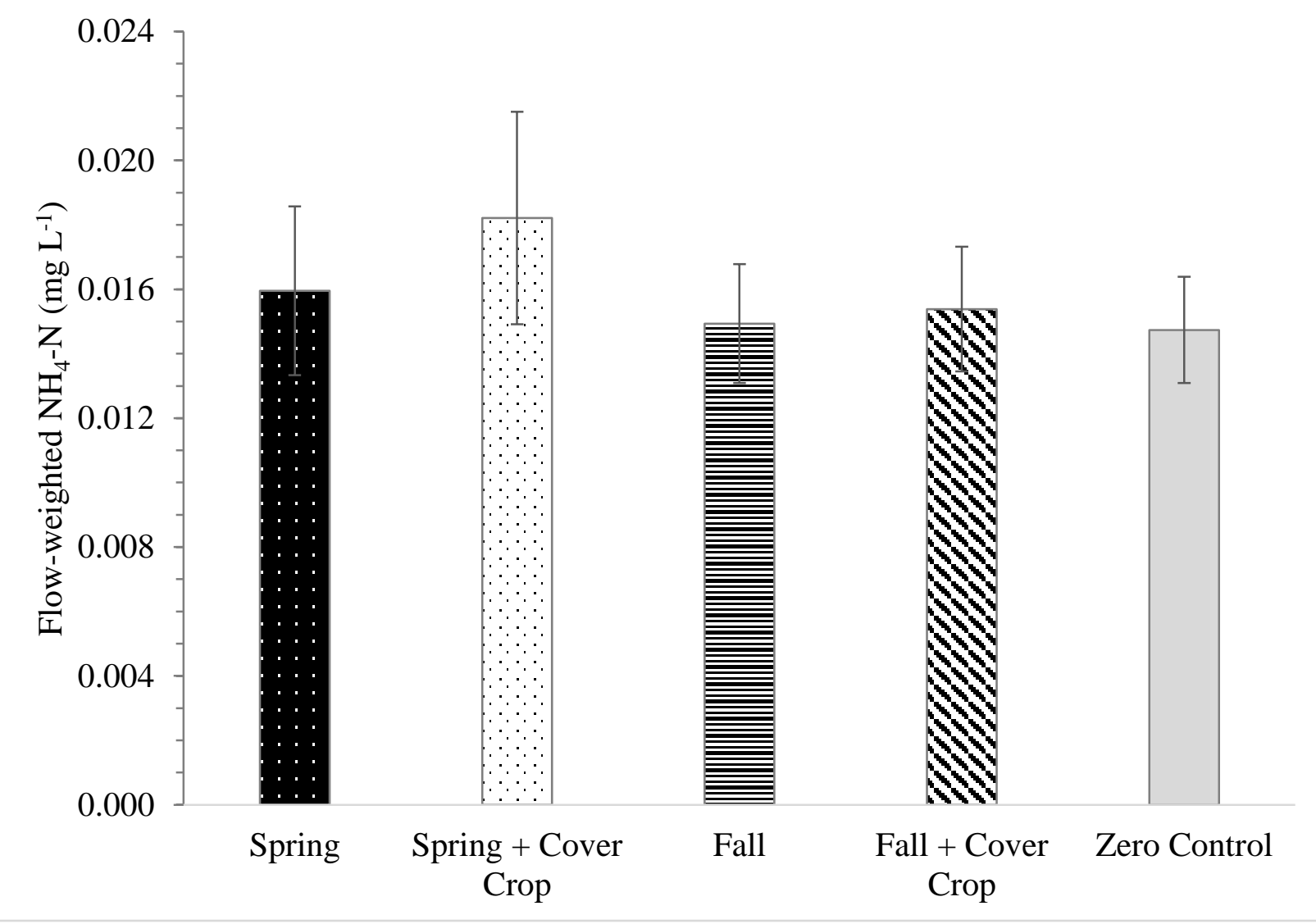

Figure $B$-13. Average flow-weighted $\mathrm{NH}_{4}-\mathrm{N}$ concentration for each treatment across the course of the study. Error bars represent the standard error. 


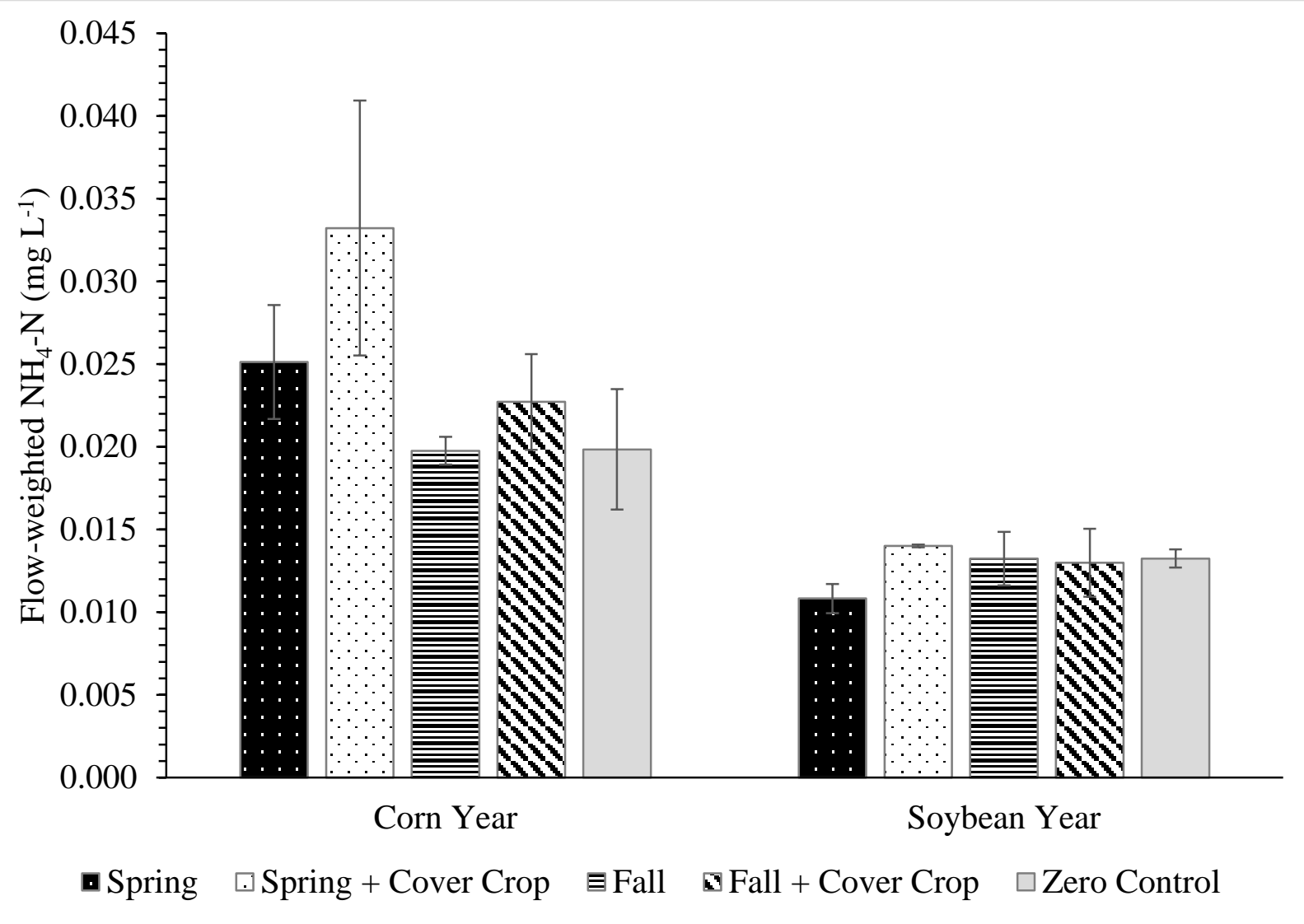

Figure B-14. Average flow-weighted $\mathrm{NH}_{4}{ }^{-} \mathrm{N}$ concentration for each treatment in the 2015 corn and 2016 soybean year. Error bars represent the standard error. 


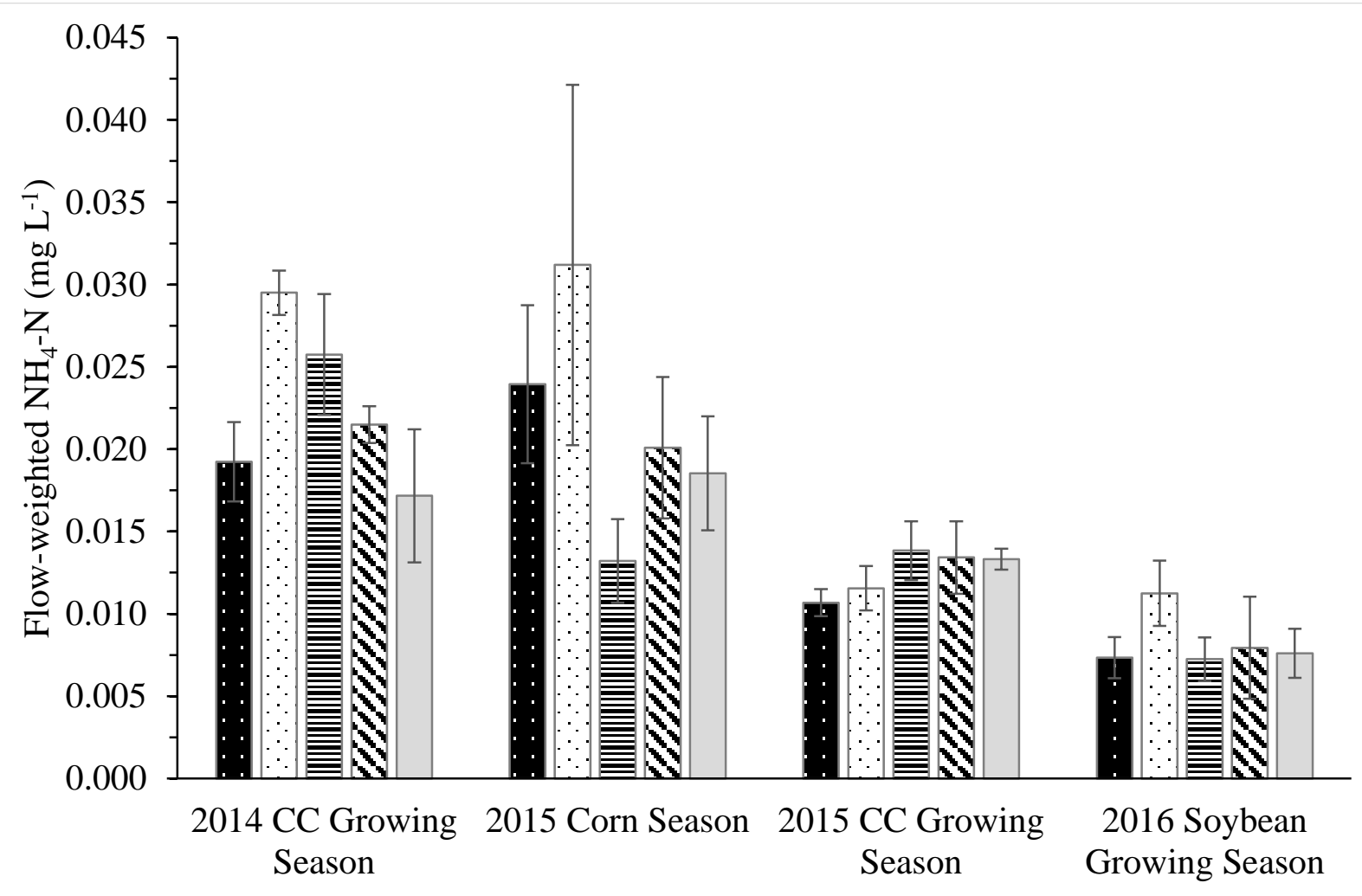

- Spring $\square$ Spring + Cover Crop $\quad \equiv$ Fall $\quad$ a Fall + Cover Crop $\square$ Zero Control

Figure B-15. Average flow-weighted $\mathrm{NH}_{4}^{-} \mathrm{N}$ concentration for each treatment within each season. Error bars represent the standard error. 


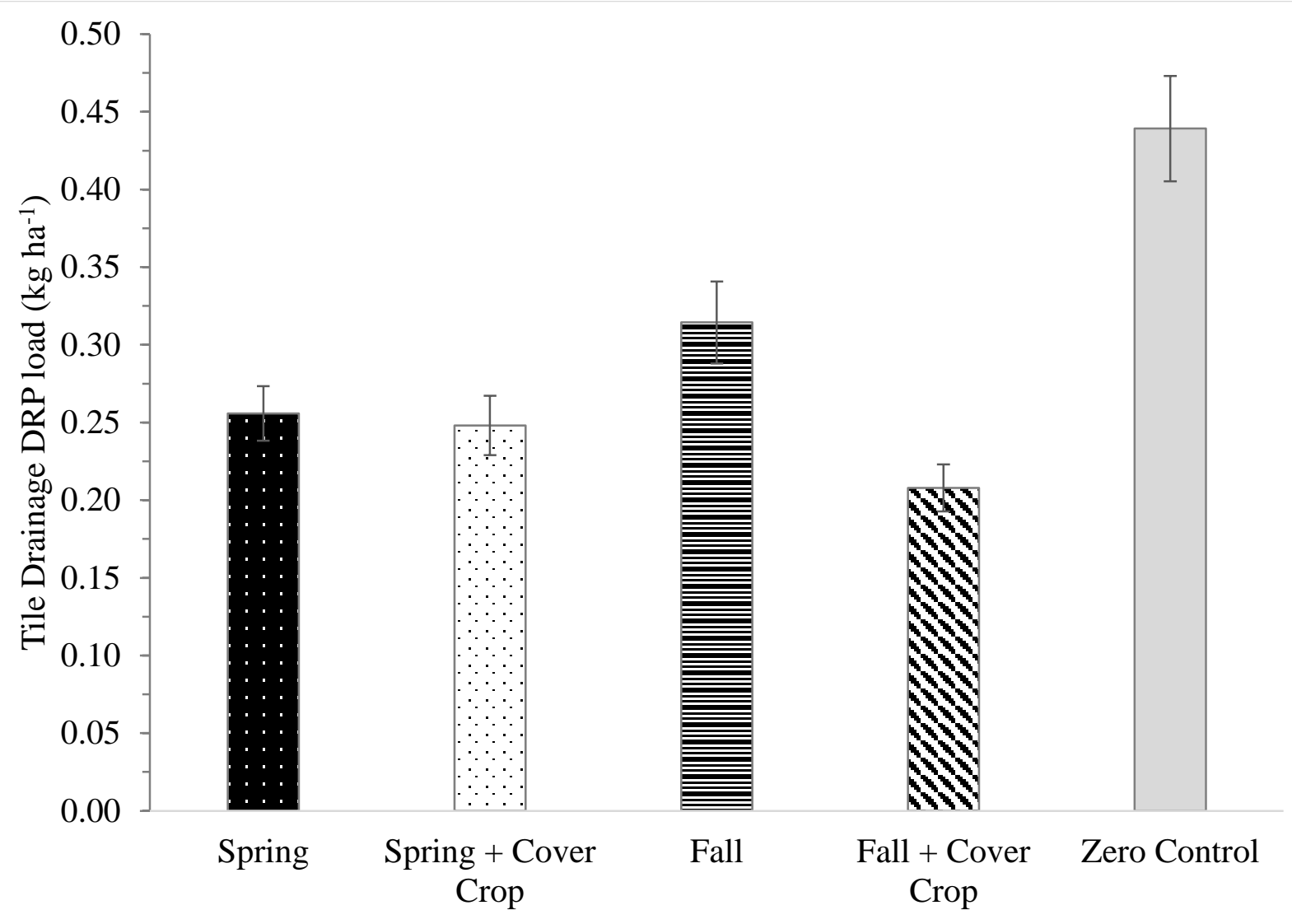

Figure B-16. Total DRP load of the tile drainage for each treatment from across the course of the study. Error bars represent the standard error. 


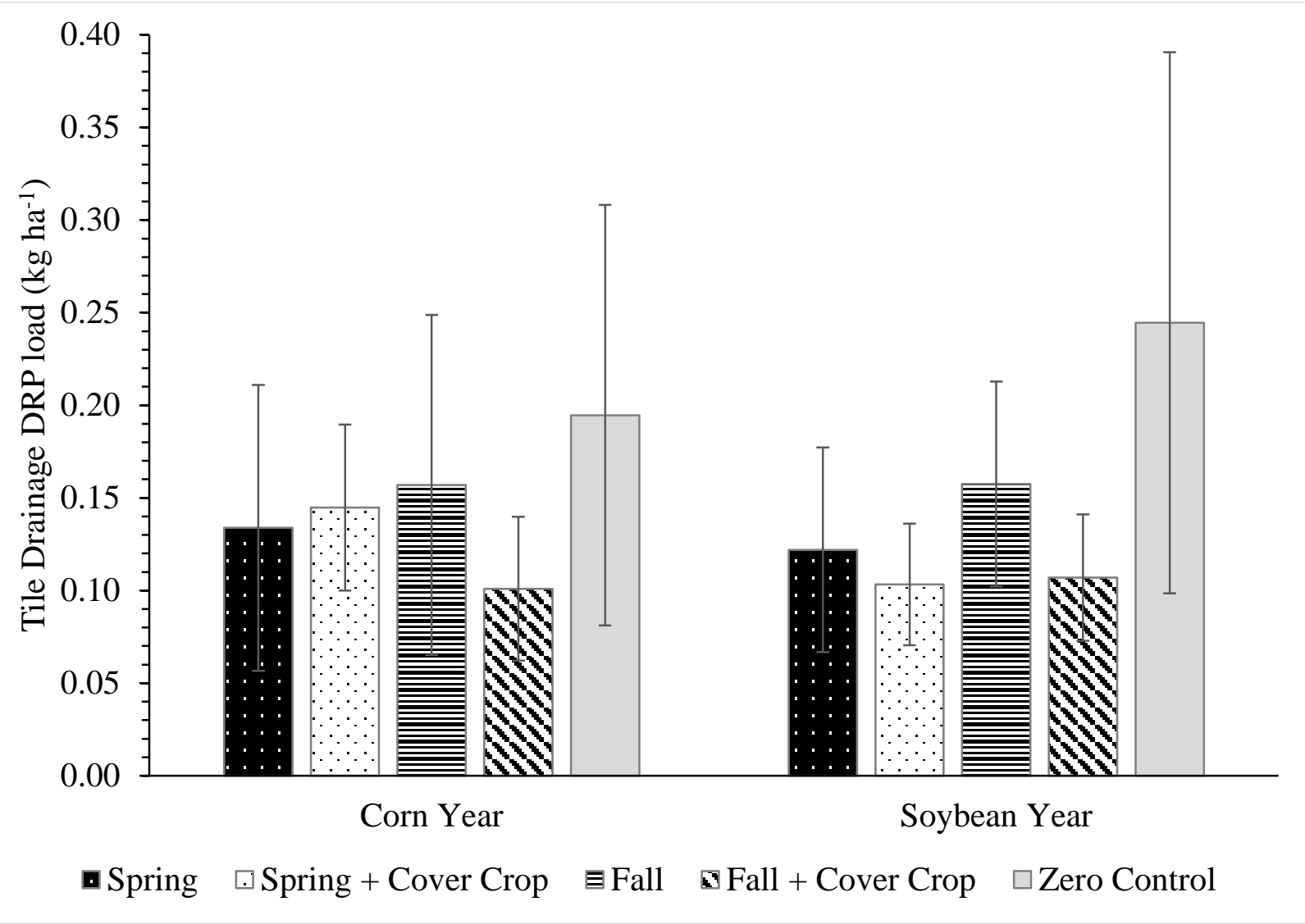

Figure B-17. Cumulative DRP load for each treatment within the 2015 corn and 2016 soybean year. Error bars represent the standard error. 


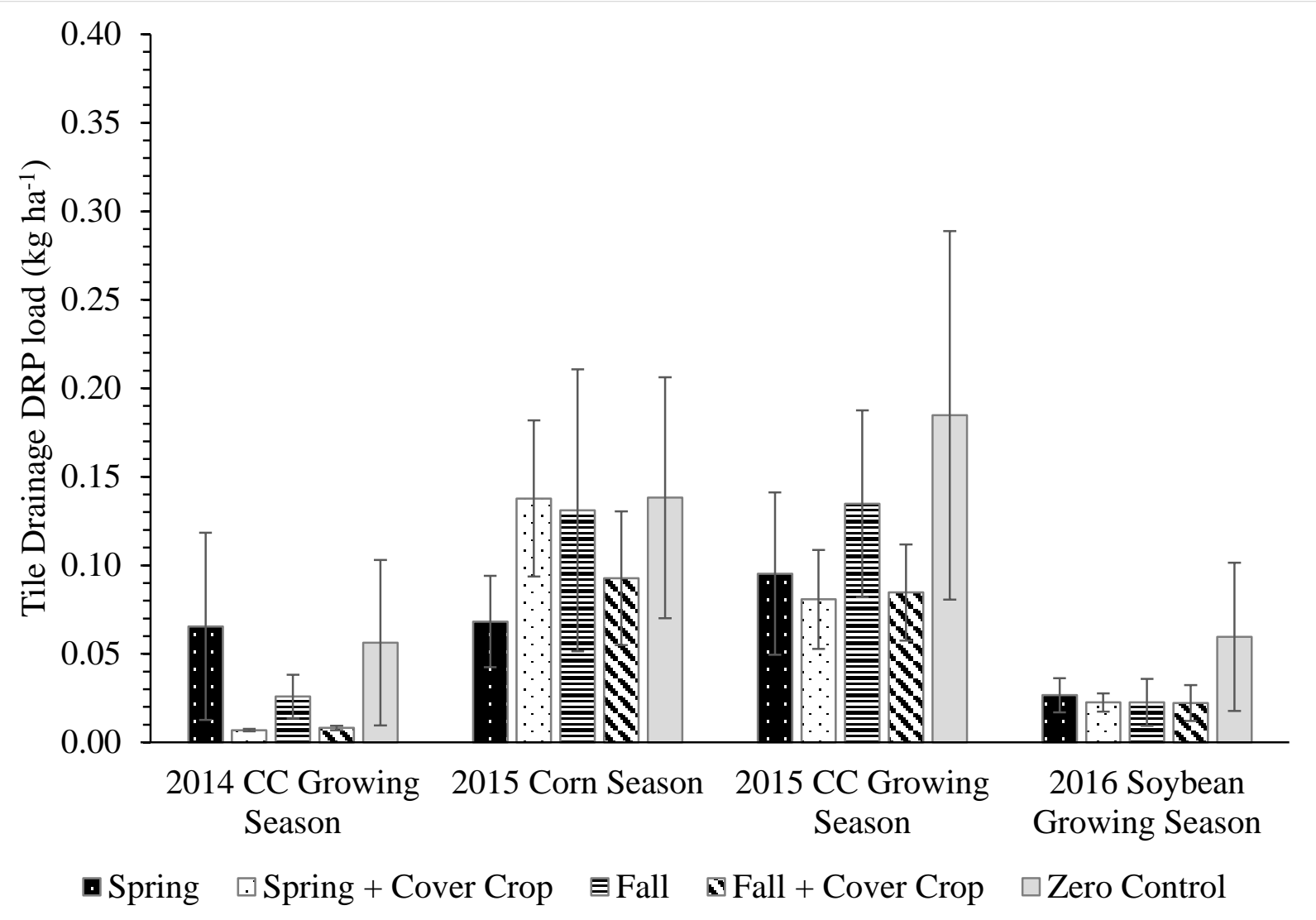

Figure B-18. Cumulative DRP load for each treatment within the each season. Error bars represent the standard error. 


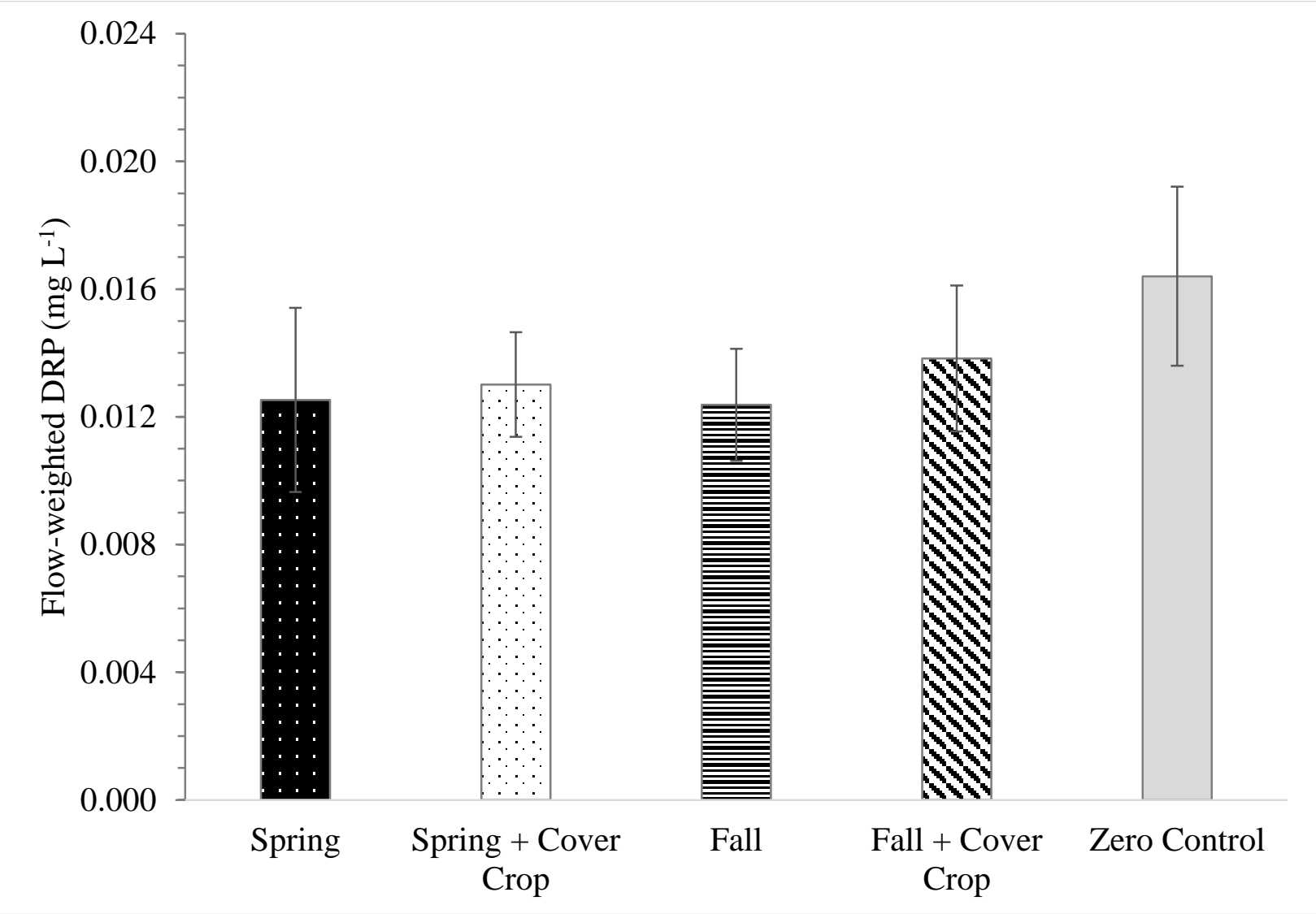

Figure B-19. Average flow-weighted DRP concentration for each treatment across the course of the study. Error bars represent the standard error. 


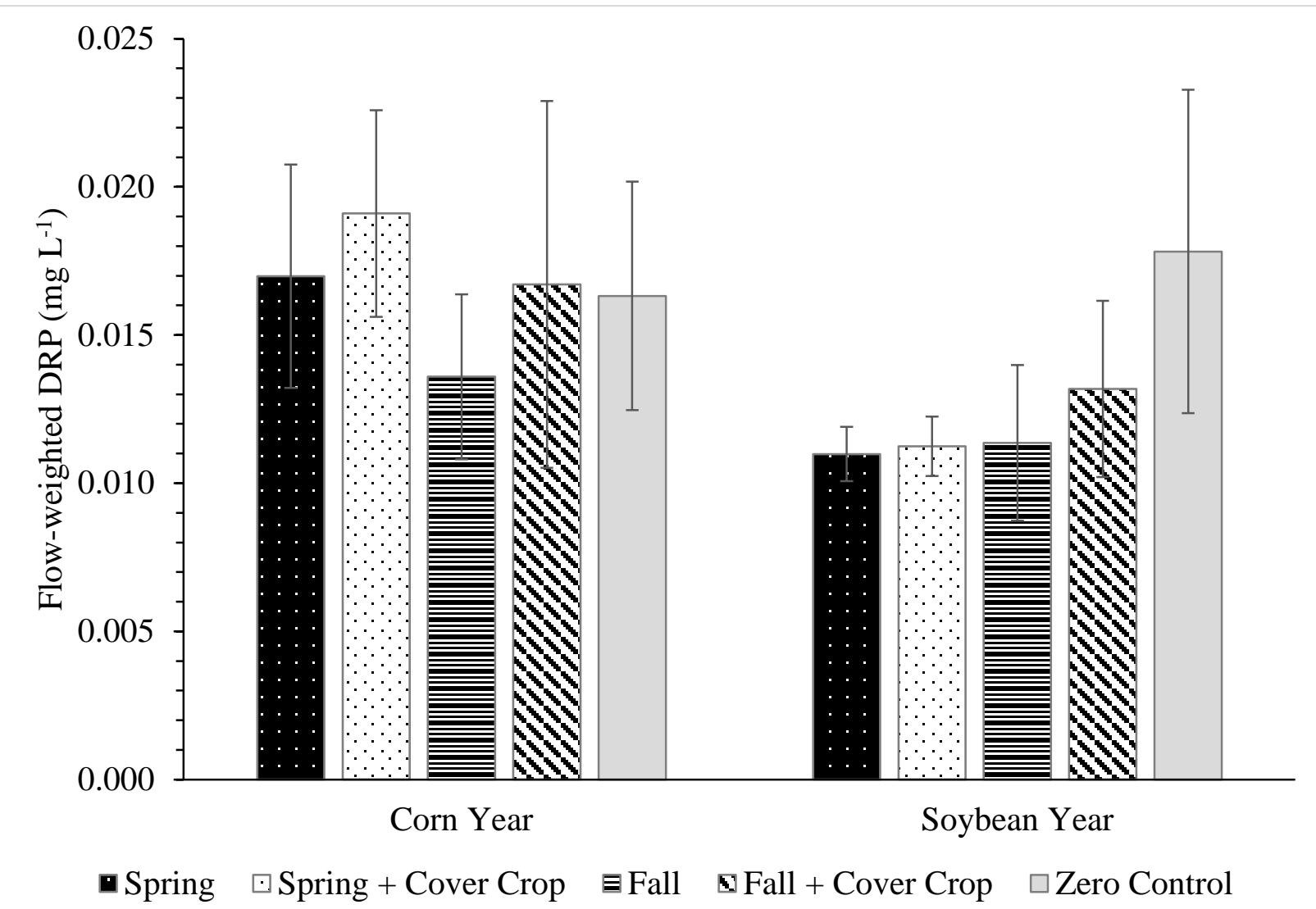

Figure B-20. Average flow-weighted DRP concentration for each treatment in the 2015 corn and 2016 soybean year. Error bars represent the standard error. 


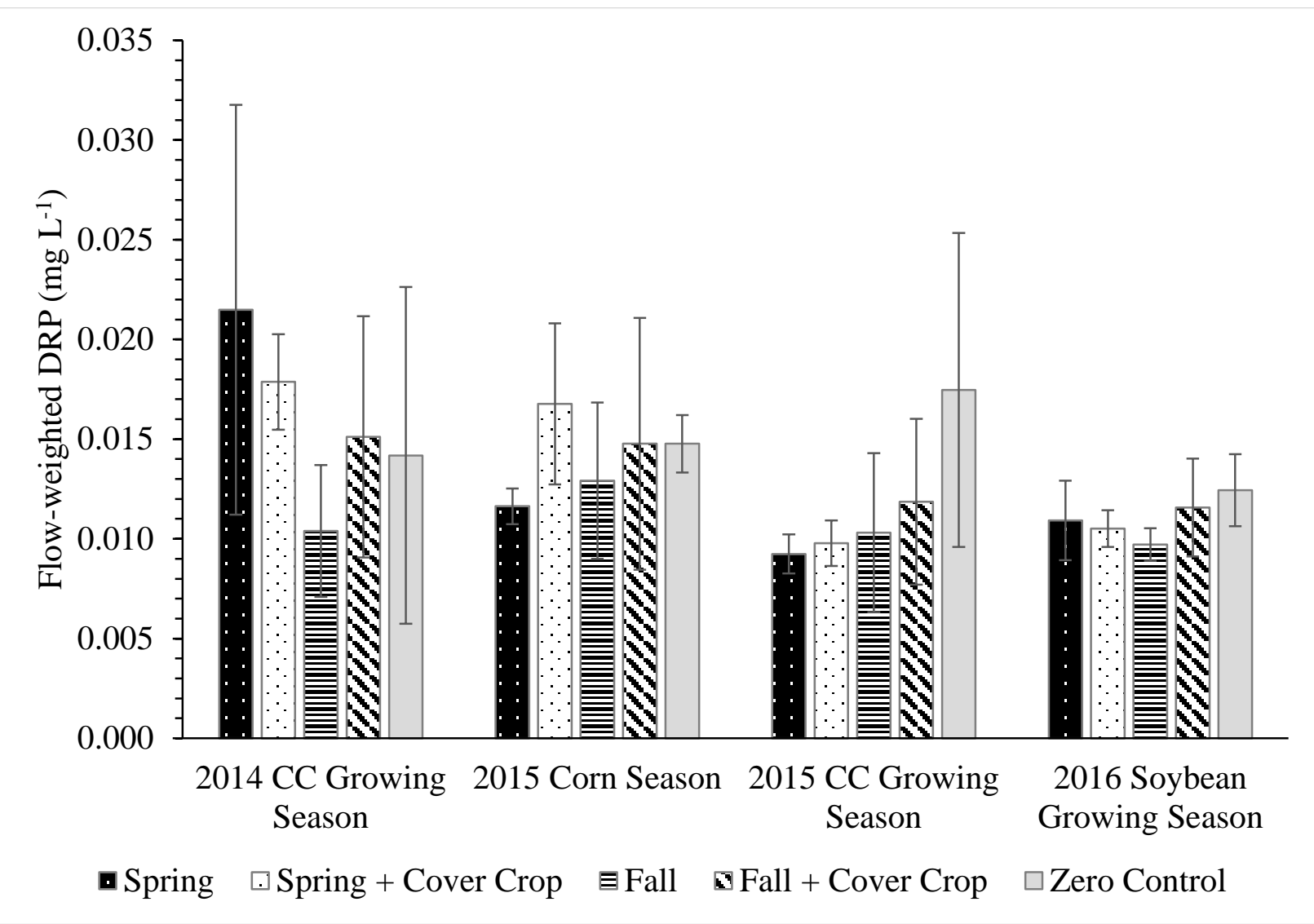

Figure B-21. Average flow-weighted DRP concentration for each treatment within each season. Error bars represent the standard error. 